Sarah L. Burns

International Forest Policy by International and Transnational Organizations

Case Studies of World Bank and Forest Certification Organizations in Argentina and Armenia 

Sarah L. Burns

International Forest Policy by International and Transnational Organizations

This work is licensed under a Creative Commons Attribution-ShareAlike 4.0

International License.

(c) (†) (?) 
erschienen in der Reihe der Universitätsdrucke im Universitätsverlag Göttingen 2016 
Sarah L. Burns

International Forest Policy

by International and Transnational

Organizations

Case Studies of the World Bank and

Forest Certification Organizations

in Argentina and Armenia

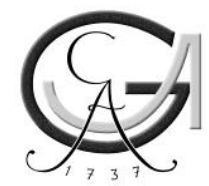

Universitätsverlag Göttingen

2016 
Bibliographic information published by the Deutsche Nationalbibliothek

The Deutsche Nationalbibliothek lists this publication in the Deutsche Nationalbibliografie; detailed bibliographic data are available on the Internet at http://dnb.dnb.de.

Address of the Author

Sarah L. Burns

Email: salibu@agro.unlp.edu.ar

Dissertation submitted in partial fulfilment of requirements for the degree of Doctor of Philosophy (PhD) Faculty of Forest Sciences and Forest Ecology

Georg-August-Universität Göttingen

Supervisor: Prof. Dr. Max Krott

Supervisor: Dr. Lukas Giessen

This work is protected by German Intellectual Property Right Law.

It is also available as an Open Access version through the publisher's homepage and the Göttingen University Catalogue (GUK) at the Göttingen State and University Library (http://www.sub.uni-goettingen.de).

The license terms of the online version apply. 


\section{ACKNOWLEDGEMENTS}

I wish to thank the following people who over the last three years and a half offered me their help and support in different ways.

In the first place I would like to thank Prof. Krott for giving me the opportunity to join his group. His critical comments throughout my PhD and vast knowledge in forest policy allowed me to improve my work as well as giving me the opportunity to learn a lot. All our many discussions helped me understand a lot about bureaucratic politics, actors' interests and power. Although we did not always agree, he always gave me the opportunity of discussing our ideas and by this he helped me understand different theories of forest policy analysis.

I would also like to express my gratitude to Prof. Daniela Kleinschmit for reviewing this thesis. During my $\mathrm{PhD}$ I had the chance to meet with Prof. Kleinschmit in different conferences and in every occasion her critical questions in my presentations helped me to improve my work considerably. By her always positive attitude as well as her excellent scientific career she became a role model for me and I am very proud of having the chance to have her as an examiner of my dissertation.

As well I would like to thank Prof. Bürger-Arndt for agreeing to review this thesis. Her background in nature conservation and experience in the field gives an added value to this dissertation.

I would specially like to thank Dr. Lukas Giessen, my daily supervisor, for his constant support and guidance, encouraging and helping me to grow as a researcher and scientist. In our daily interactions he has been always available to discuss ideas, manuscripts and field work assistance. By working with him I was able to develop many different skills in international relations, forest policy and governance as well as public policy, encouraging me by valuing my work and introducing me to a new research discipline to me, which I learned to enjoy a lot. Thank you for three wonderful years of constant learning.

I also want to thank all my colleagues in the International Forest Policy Working Group: Jacqui, Alif, Saifur and Agung and for a short but great time Carmen. We grew together professionally in the last three years by sharing many discussions about our progress and supporting each other in the process of writing our thesis. As well I want to thank all the other PhD students in the Chair of Forest and Nature Conservation Policy: Janina, Kenji, Huong, Budi, Carsten, Manjola and all other PhD students, some who have already finished for sharing with me daily work activities.

A special "Gracias!" goes to all my colleagues and friends from the Laboratorio de Sistemas Ecológicos y Ambientales (LISEA) from the National University of La Plata in Argentina, for making me feel that I never left and giving me their usual support and friendship over skype meetings, emails and chats. To Carolina Perez, Marcelo Arturi and Marcelo Barrera for their support from the beginning, not only during these past years but ever since I first started working in the LISEA allowing me to be part of this extraordinary working group. I especially want to thank Juan Goya and Pablo Yapura, 
who not only replaced me in my teaching activities in Argentina, but also encouraged me and helped me to grow ever since I was a forestry student giving me later the chance to work with them, and by this join this incredible group of colleagues and friends.

I will be eternally grateful to the National University of La Plata (Universidad Nacional de La Plata) for having trained and educated me gratuitously and for granting me a leave of absence that allowed me to come to Germany to do my PhD studies. I am extremely proud of belonging to the UNLP as a student, graduate and teacher.

I also want to thank my friends and family (de sangre $y$ de ketchup) back in Argentina. For the past three years you supported me over the phone in so many occasions, always being with me in the good and in the bad times. One thing I learned over these past years is that not even an ocean can bring us apart. Gracias por estar siempre!

I would like to thank Kerstin Wiegand, Katrin Meyer and all the Ecosystem Modelling group for including me in so many activities and sharing so many fun and delicious lunches in the Nordmensa together making me feel as part of the group.

Last but not least, I want to thank my friends in Germany for all the nice times spent together. Without you I would not have been able to enjoy these past three years the way I did, hanging out in our living room in Schröders watching football and drinking beer. Thanks to you I feel at home in Göttingen. A special thank goes to Bettina for being the most amazing friend to me since I first arrived, introducing me to basically everyone I know in Göttingen, teaching me to color eggs for Easter and as Daisy said, showing me that black and yellow are the best colors ever! To Daisy, for sharing so many moments and talks about our experiences and feelings, even though you like black and I like pink and for teaching me a completely new Spanish. Gracias Daisyta por estar siempre! To Yasmin, my official German translator, for all the emotional and practical help throughout these years, without them I would have been lost. Sonderbar and I are very grateful for having you in our lives! To Natalia, for all the long and crazy talks that make it impossible to be bored or sad. Nubecito, te quiero mucho! I don't want to forget anyone, Niki, Kaufi, Torben, Paul, Meik, Marc, Matteo, Federico (the disgusting rat), Iris, Urs, Maria (Rose), Nele (our sweet Nonna), Mike (Irish rat), Martyna, Per, Anna, Thomas, all of you are the reason life in Göttingen has been fun and warm.

For all of you....

\section{Gracias Totales!}




\section{Summary}

In recent decades, globalization and internationalization led to an increase in the number of international policies and regimes as well as the creation of a new form of governance based on voluntary agreements, attempting to influence national behaviour over many different issues. The complexity and fragmentation in global governance arrangements matches the complexity at the domestic level with whom they interact. Findings from public policy analysis suggest that especially the interaction between international regimes and domestic, mostly national bureaucracies is crucial being analyzed since it is in this interaction where the politics of competing domestic bureaucracies have a strong bearing on the influence international actors and institutions will be able to develop.

By using the case of the international forest regime complex this thesis seeks to evaluate how an international organization such as the World Bank and private institutions of forest certification influence domestic forest policy. The cases of Argentina and Armenia were selected as examples of developing countries open to international influences with weak forest sectors that went through a recent administrative restructuring. In so doing this dissertation seeks to answer how do international and transnational organizations influence domestic forest policies?

In order to address this question, four articles addressing specific questions in selected study cases were developed.

Article 1. Burns, S. L. and L. Giessen. 2014. Identifying the main actors and their positions on international forest policy issues in Argentina. Bosque 32(2): 163-173. This article identifies the most relevant forest issue elements in Argentina as well as the main actors involved and their positions towards them as a result of their interests.

Article 2. Burns, S. L. and L. Giessen. 2016. Dismantling Comprehensive Forest Bureaucracies: Direct Access, the World Bank, Agricultural Interests, and Neoliberal Administrative Reform of Forest Policy in Argentina. Society and Natural Resource 29(4): 493-508. This article analyzes the influence the World Bank exerted on domestic forest policy-making and bureaucratic reform in Argentina resulting in new forest laws that, as a whole, benefited plantation forests and regulated soy production expansion. This policy was found to be supported by a coalition of the World Bank, agricultural interests and private landowners.

Article 3. Burns, S. L., Yapura, P.F. and L. Giessen. 2016. State actors and international forest certification policy: Coalitions behind FSC and PEFC in federal Argentina. Land Use Policy 52: 23-29. This publication analyzes the role state agencies played in the forest certification standard development processes in Argentina, including the related coalition building strategies.

Article 4. Burns, S. L., Krott, M., Sayadyan, H. and L. Giessen. The World Bank's power on environmental and natural resources policies in Armenia: neoliberal changes and post-soviet heritage. Under review in World Development. This article analyzes the World Bank's power resources and its resulting influence on environmental and natural resources policies under the umbrella of poverty alleviation projects in a post-socialist fragile state using Armenia as a case. 
In order to answer the main research question these four articles addressed more detailed questions:

I. Who are the dominant actors in forest policy?

II. What domestic allies, state and non-state, do international and transnational organizations have?

III. Which coalitions made by international and transnational organizations are more frequent? With state bureaucracies or with non-state allies?

IV. How stable are these coalitions? Are they permanent or dynamic?

V. What are the factors to break up coalitions?

Two cases with strong political dynamics in the forest sector and strong intervention by the World Bank and with additionally good field access, Argentina and Armenia, were selected with the aim to obtain empirical rich evidence for testing the hypothesis needed. The thesis focused on two main sources of data: written documents and semi-structured interviews with experts. In total approximately 60 interviews were carried out, 50 in Argentina and 10 in Armenia between October 2012 and September 2014. In addition around 150 documents from both public and expert sources were analyzed in the same time period. Process tracing was used to understand how international and transnational organizations influence policy change in the domestic level through direct access and market mechanisms. In all cases data was analyzed by means of qualitative content analysis.

The results show that, first, which issues become relevant in different countries depends on the domestic actors and their interests leading to differences in the relevant issues in each country, as observed from the issues detected in Argentina which were not the same as the relevant subjects found in similar studies conducted in Indonesia and Bangladesh although some similarities were observed. Second, by means of funding and capacity building, the World Bank, as an international organization, assisted the coalition of agricultural and profit-oriented bureaucracies and landowner associations (of forestry and agriculture) that emerged after the economic crisis in the country at the beginning of the 1990s. The intervention of the World Bank in the reform of forest policy in Argentina figured prominently in the form of new forest laws that, as a whole, benefited plantation forests and opened land for agricultural production. Third, the influence of the World Bank in Argentina and Armenia through direct access by funding projects aiming at poverty alleviation and sustainable natural resources management pushed the forest sector towards deregulation. Following a framework of neoliberal conservation governance, promoting market-based mechanisms that aim to motivate local users to address environmental concerns by means of incentives, the World Bank promoted the intensification of natural resources production both in the case of Argentina and Armenia. Although seen as a fundamental step towards sustainability, these neoliberal conservation policies have been criticized for informally promoting decentralization, privatization and commodification that allow corporations and international actors to increase their influence over local natural resources. Fourth, state bureaucracies play an important role in the implementation of transnational regimes at the national level. In forest certification processes international actors seek coalitions with different state bureaucracies. However, in situations where new promising venues for political influence open, private actors prefer ad hoc coalitions with weaker bureaucracies that would not be permanent and with less technical knowledge. Fifth, the political system of federal countries like Argentina provides multiple institutional access points for policy change that international 
and transnational regimes try to use in order to influence the domestic level, consequently changing the power balance of the domestic networks. Domestic actors then can use these regimes to shift the power balance in their favor. This was observed in Argentina where national bureaucracies benefited by gaining influence through the implementation of the International Forest Regime Complex. 


\section{Table of Contents}

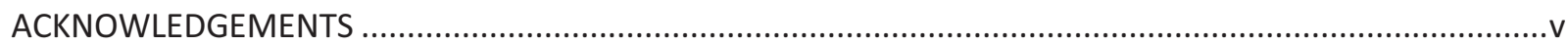

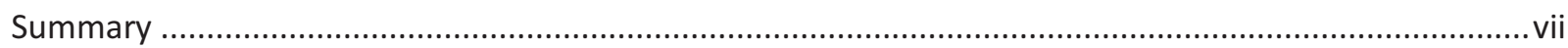

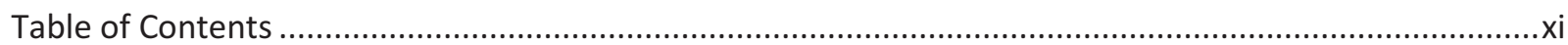

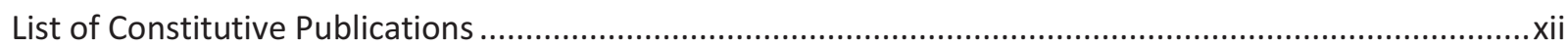

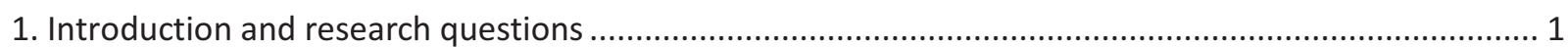

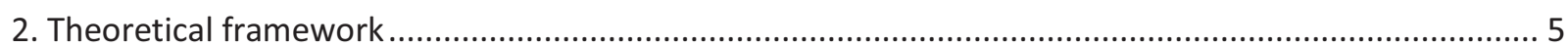

2.1. International Organizations - The World Bank ............................................................ 5

2.2. Transnational Organizations - Forest Certification................................................................ 5

2.3. Pathways of influence used by international and transnational organizations ........................... 6

2.4. Domestic actors and bureaucratic politics theory ........................................................ 7

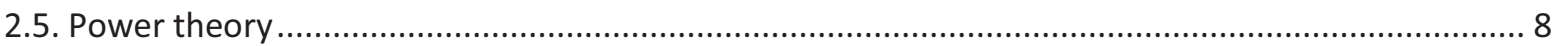

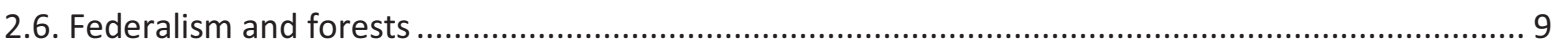

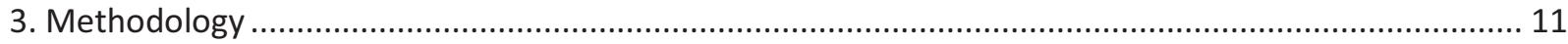

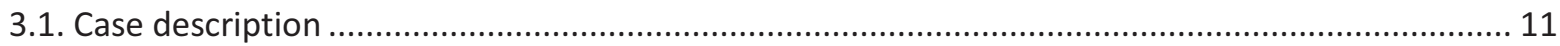

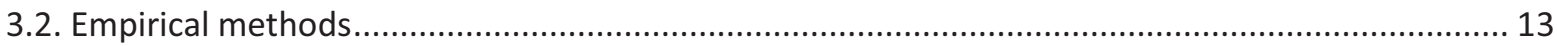

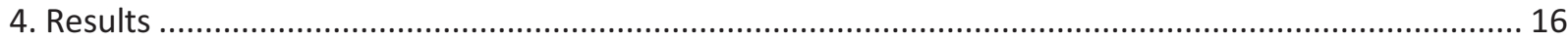

4.1. Relevance of the International Forest Regime Complex by powerful actors ............................. 16

4.2. The World Bank and domestic forest policy ................................................................. 18

4.3. The World Bank leading to deregulation and weak bureaucratic structures ............................. 19

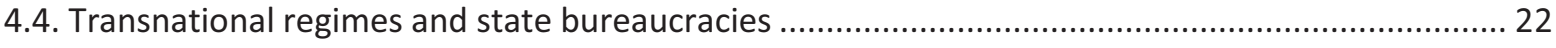

4.5. Federalism and International and Transnational forest regimes .......................................... 23

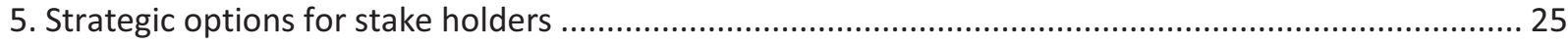

5.1. Directorate for Forestry Production, Ministry of Agriculture ............................................. 25

5.2. Directorate for Native Forests, Secretariat of Environment and Sustainable Development.......... 26

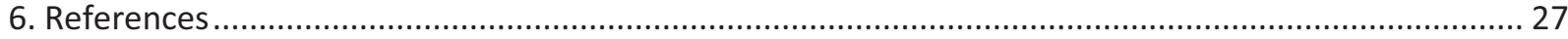

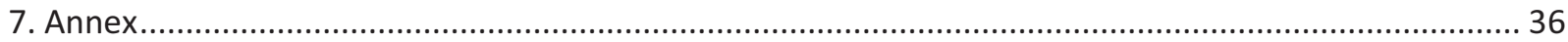




\section{List of Constitutive Publications}

1. Burns, S. L. and L. Giessen. 2014. Identifying the main actors and their positions on international forest policy issues in Argentina. Bosque 32(2): 163-173. http://dx.doi.org/10.4067/S0717-92002014000200004

2. Burns, S. L. and L. Giessen. 2016. Dismantling Comprehensive Forest Bureaucracies: Direct Access, the World Bank, Agricultural Interests, and Neoliberal Administrative Reform of Forest Policy in Argentina. Society and Natural Resource 29(4): 493-508.

http://dx.doi.org/10.1080/08941920.2015.1089608

3. Burns, S. L., Yapura, P. F. and L. Giessen. 2016. State actors and international forest certification policy: Coalitions behind FSC and PEFC in federal Argentina. Land Use Policy 52: 23-29. http://dx.doi.org/10.1016/j.landusepol.2015.12.005

4. Burns, S. L., Krott, M., Sayadyan, H. and L. Giessen. The World Bank's power on environmental and natural resources policies in Armenia: neoliberal changes and post-soviet heritage. Under review in World Development.

\section{Complementary Publications}

5. Giessen, L., Burns, S. L., Sahide, A. M. K., Wibowo, A. 2016. From governance to government: The key role of state bureaucracies in forest and agricultural certification. Policy and Society 35: 71-89. http://dx.doi.org/10.1016/i.polsoc.2016.02.001.

6. Sahide, A., Burns, S. L., Wibowo, A., Nurrochmat, D. R., Giessen, L. 2015. Towards state hegemony over agricultural certification: from voluntary private to mandatory state regimes on palm oil in Indonesia. Jurnal Manajemen Hutan Tropika 21: 162-171.

http://journal.ipb.ac.id/index.php/jmht/article/view/10798

7. Burt, B., Burns, S. L., Sahide, A., Wibowo, A., Giessen, L. 2016. Governments reclaiming role in forest certification. IUFRO Spotlight \#39 / July 2016. IUFRO, Vienna, online under http://www.iufro.org/media/iufro-spotlights/ 


\section{Introduction and research questions}

In recent decades, globalization and internationalization led to an increase in the number of international policies and regimes attempting to influence national behaviour over many different issues (Lindstad and Solberg 2010). This rise in international regimes dealing with issues as different as development cooperation, health, trade, agriculture, environment and forests among others brought along a burst of research on regime compliance and effectiveness both in the field of international relations as well as in environmental policy (Hisschemöller and Gupta 1999, Sprinz and Helm 1999, Helm and Sprinz 2000, Young 2001, 2003, Hovi et al. 2003, Sprinz 2005, Bernstein and Cashore 2012).

An international regime is defined as a "set of implicit or explicit principles, norms, rules and decisionmaking procedures around which actors' expectations converge in a given area of international relations" (Krasner 1982, 186). Although originally these regimes aimed at constraining or modifying the external behaviour of states, a new generation of international regimes which boomed mainly after the Rio Summit in 1992, attempt to influence domestic practices, policies and policy-making processes (Bernstein and Cashore 2012).

At the same time international regimes boomed, and with the increased participation of non-state actors, a new form of governance based on voluntary agreements was created. This new form of private governance has been referred to as transnational regimes. The main difference between international and transnational regimes is that in the latter, non-state actors generate the set of norms and rules instead of states (Pattberg 2012). As a result, current governing arrangements are no longer represented by single-issue regimes with states as only actors, but rather by a mixture of mechanisms including legal, non-legal, governmental and non-governmental arrangements (Bernstein and Cashore 2012).

The new complex global governance arrangements led Bernstein and Cashore $(2010,2012)$ to propose a change in focus, moving away from regime compliance and effectiveness into influence. According to the authors the means by which international regimes may exert their influence at the domestic level can be categorized into "four pathways of influence, each with its own causal logic: international rules (the traditional focus of regime effectiveness literature); international norms and discourse; creation of or interventions in markets; and direct access to domestic policy processes" (Bernstein and Cashore 2012, 587). It is "the interaction of mechanisms and processes, sometimes along multiple pathways, that create collective influence" (Bernstein and Cashore 2012, 603).

The complexity and fragmentation in global governance arrangements matches the complexity at the domestic level with whom they interact. Compliance and effectiveness approaches have so far considered the interaction in only one direction, that is, from the international level to the domestic level. However, influence in the opposite direction also occurs when national states exert influence over the international processes blurring the boundaries between global and domestic politics (Lindstad and Solberg 2010, Bernstein and Cashore 2012). Findings from public policy analysis suggest that especially the interaction between international regimes and domestic, mostly national bureaucracies is crucial being analyzed (Hofmann 2002, Krott 2005, Hogl et al. 2009, McDermott et al. 2010, Peters 2010). It is in this interaction where the politics of competing domestic bureaucracies have a strong bearing on the influence international actors and institutions will be able to develop (Bernstein and Cashore 2012). 
The International Forest Regime is a good example of a complex and fragmented regime without a single legally binding agreement, but rather a set of different instruments dealing directly or indirectly with different aspects of the world's forests (Humphreys 1999, 2006, Arts and Babili 2012, Giessen 2013). The complexity of this regime led scholars to introduce the term International Forest Regime Complex (Glück et al. 2010, Howlett and Rayner 2010, Rayner et al. 2010). A regime complex can be defined as a "set of specialized regimes and other governance arrangements that are more or less loosely linked together, sometimes reinforcing each other but at other times overlapping and conflicting" (Giessen 2013, 62). So far the international forest regime complex has been described as fragmented (Humphreys 1999, 2006, Glück et al. 2010, Howlett et al. 2010, Rayner et al. 2010, Giessen 2013), hollow (Dimitrov 2005, Dimitrov et al. 2007, Giessen 2013), ineffective (Humphreys1999, 2006, Dimitrov 2005, Giessen 2013) and a failure (Dimitrov 2005, Smouts 2008, Giessen 2013). However, Giessen (2013) claims that the main characteristic of the international forest regime complex is its fragmentation, which also explains the other three attributes. Fragmentation can be defined as "a patchwork of international institutions that are different in their character (organizations, regimes, and implicit norms), their constituencies (public and private), their spatial scope (from bilateral to global), and their subject matter (from specific policy fields to universal concerns)" (Biermann et al. 2009, 16). According to Biermann et al. (2009) all global governance arrangements show some degree of fragmentation. These characteristics of the international forest regime complex might be the result of a global tacit agreement on having a weak and hollow forest regime and not just a lack of consensus between actors leading to what has been defined as a non-regime (Dimitrov 2005, Dimitrov et al. 2007). As pointed out by many authors, these fragmented regime complex is the result of the different interests of the actors involved. While it benefits both Northern and Southern states (Humphreys 2006) it also benefits transnational non-state actors and institutions (Arts and Buizer 2009, Pattberg 2007). The benefits of the fragmentation are not only observed at the international level but also at the domestic level, where different bureaucracies competing among each other over a certain issue would benefit differently from the regime (Gulbrandsen 2003, Hogl et al. 2009, Giessen 2013).

For a fragmented regime complex, as the international forest regime complex, to influence domestic policies at national levels, it depends on international and especially domestic coalition partners (Humphreys 2006, Bernstein and Cashore 2012). These can include international as well as domestic state and non-state actors. Special attention, however, must be paid to domestic bureaucracies, as they have to invite international actors due to sovereignty principles and in the domestic policymaking process they are instrumental in developing policies including also regulatory instruments. A research program on international forest policy that examines the pathways and politics through which international institutions influence such domestic policy change is currently being developed (Arts and Babili 2012; Bernstein and Cashore 2012).

By using the case of the international forest regime complex this thesis seeks to evaluate how an international organization as the World Bank and private institutions of forest certification influence domestic forest policy. The cases of Argentina and Armenia were selected as examples of developing countries open to international influences with weak forest sectors that went through a recent administrative restructuring.

In so doing this thesis poses the following research questions: 


\section{How do international and transnational organizations influence domestic forest policy?}

In order to answer the main research question more detailed questions are proposed:

- Who are the dominant actors in forest policy?

- What domestic allies, state and non-state, do international and transnational organizations have?

- Which coalitions made by international and transnational organizations are more frequent? With state bureaucracies or with non-state allies?

- How stable are these coalitions? Are they permanent or dynamic?

- What are the factors to break up coalitions?

These questions will be addressed in a cumulative PhD dissertation consisting of 6 peer-reviewed publications. A brief description of the four core publications and the contributions made by the author of this dissertation (marked in bold) as well as by the other authors is detailed below.

Article 1. Burns, S. L. and L. Giessen. 2014. Identifying the main actors and their positions on international forest policy issues in Argentina. Bosque 32(2): 163-173. This article identifies the most relevant forest issue elements in Argentina as well as the main actors involved and their positions towards them as a result of their interests. Burns, as the first and main author of this publication applied theory, hypothesis and methodology to the case as well as findings regarding the implementation of the main forest issue elements from the international forest regime complex in Argentina. Giessen developed the general theory, hypothesis and methodology.

Article 2. Burns, S. L. and L. Giessen. 2016. Dismantling Comprehensive Forest Bureaucracies: Direct Access, the World Bank, Agricultural Interests, and Neoliberal Administrative Reform of Forest Policy in Argentina. Society and Natural Resource 29(4): 493-508. This article analyzes the influence the World Bank exerted on domestic forest policy-making and bureaucratic reform in Argentina resulting in new forest laws that, as a whole, benefited plantation forests and regulated soy production expansion. This policy was found to be supported by a coalition of the World Bank, agricultural interests and private landowners. Burns, as the first and main author of this publication applied theory, hypothesis and methodology to the case as well as findings regarding the influence of international organizations on domestic forest policy change. Giessen developed the general theory, hypothesis and methodology.

Article 3. Burns, S. L., Yapura, P. F. and L. Giessen. 2016. State actors and international forest certification policy: Coalitions behind FSC and PEFC in federal Argentina. Land Use Policy 52: 23-29. This publication analyzes the role state agencies played in the forest certification standard development processes in Argentina, including the related coalition building strategies. Burns, as the first and main author of this publication applied theory, hypothesis and methodology to the case as well as findings regarding the influence of transnational regimes and the role of state bureaucracies in an initiative that was so far claimed as non-state private governance. Yapura applied methodology to the case and produced case findings regarding the development of FSC in Argentina. Giessen developed the general theory, hypothesis and methodology. 
Article 4. Burns, S. L., Krott, M., Sayadyan, H. and L. Giessen. The World Bank's power on environmental and natural resources policies in Armenia: neoliberal changes and post-soviet heritage. Under review in World Development. This article analyzes the World Bank's power resources and its resulting influence on environmental and natural resources policies under the umbrella of poverty alleviation projects in a post-socialist fragile state using Armenia as a case. Burns, as the first and main author of this publication developed and applied theory, hypothesis and methodology to the case as well as findings regarding the influence of international organizations in fragile states through environmental policy change. Krott and Giessen developed the general theory, hypothesis and methodology. Sayadyan applied methodology to the case and produced case findings regarding the outcome of the World Bank projects in Armenia. 


\section{Theoretical framework}

\subsection{International Organizations - The World Bank}

An international organization can be defined as "an institutional arrangement that combines three elements: a normative framework, a group of member states, and a bureaucracy as administrative core" (Bauer et al. 2012, 28). This definition allows discriminating analytically international organizations from international bureaucracies. An international bureaucracy is then defined as "a public institution which makes decisions concerning specific international problems on the basis of international law standards and international agreements, resolving those problems by implementing special measures" (Biermann et al. 2009, 37).

International organizations and their bureaucracies are considered key actors, directing patterns of global change (Singh 2009, Biermann et al. 2009). Among these organizations the World Bank is considered as perhaps the most influential actor bringing about certain types of changes in developing countries (Singh 2009, Marschinski and Behrle 2009). In order to operate the World Bank uses what is known as blueprints that include the Bank's general policy models. These blueprints are then implemented in many different countries with the expectation that they will produce the same results (Tuozzo 2009).

In dealing with forest policy the World Bank has developed three forest policy initiatives: the 1978 forestry policy, the 1991 and the 2002 forests strategies although the first loans for forestry projects date back to 1949 (Humphreys 2006). While neoliberal and interventionist elements, characteristic of the World Bank interventions in all issue areas, have always been present throughout the history of the World Bank intervention in forest policy, the different forest strategies showed some formal changes (Humphreys 2006). The 1978 forestry policy sought to fulfil the needs of the rural poor while considering the environment. However criticisms claimed that instead of helping the poor it blamed them for deforestation, prioritizing forest industries and plantation forests (Humphreys 2006). The 1991 forests strategy responded to these criticisms with a move towards a more conservationist approach emphasizing even more on poverty alleviation by means of new modes of market-based conservation mechanisms. During this time half of the World Bank's loans went to boreal and temperate forests, including the former communist countries in Eastern Europe and the former Soviet Union (Humphreys 2006). With the 2002 forests strategy the World Bank promoted private sector investment in forests, new environmental markets and voluntary private sector regulation (Humphreys 2006).

Previous research on policy change and bureaucratic reforms focused mainly on domestic factors as explanatory variables. However, international organizations like the World Bank are also important actors leading to domestic policy change (Tuozzo 2004; 2009, Burns and Giessen 2016, Burns et al. unpublished). In this thesis we try to analyze how the World Bank as an international organization influences domestic forest policy change.

\subsection{Transnational Organizations - Forest Certification}

After the Rio Summit in 1992, with the increased participation of non-state actors, a new form of governance based on voluntary agreements was created. This new form of private governance has been referred to as transnational regimes. The main difference between international and transnational regimes is that in the latter, non-state actors generate the set of norms and rules instead of states 
(Dingwerth 2005, Pattberg 2012). As well as international regimes, transnational regimes operate within a wide range of issue areas that have multiplied in the last 20 years (Dingwerth and Pattberg 2009, Pattberg 2012). The lack of credibility of intergovernmental organizations has been indicated as an explanation for transnational regimes' success by emphasizing on inclusiveness, transparency, accountability, and deliberativeness (Dingwerth and Pattberg 2009, Klinke 2009).

Through certification of forest products a new form of political steering has been promoted based on voluntary agreements with the increased participation of non-state actors. In the political science body of literature, forest certification has been so far described as a non-state, market-driven form of private governance developed by non-state actors and building on private institutions (Cashore et al. 2005, Pattberg 2007). In international policy, it is currently referred to as transnational regimes (Pattberg 2012) and more broadly discussed under the concept of forest governance (Agrawal et al. 2008, Arts 2014, Giessen and Buttoud 2014).

These perspectives in political science highlight aspects relating to the role of private actors and private institutions and the way they gain authority vis-à-vis state failure to solve forest problems, and they are accompanied by a perceived decline in power of forest related public actors and institutions (Ho 2006, Wibowo and Giessen 2015). This view, however, leaves largely underrepresented the role of the state in e.g., creating, enabling, or obstructing conditions for forest certification in general and individual certification schemes in particular. It further downplays the role of the multiple and often competing state bureaucracies in certification politics, which may be crucial as both resources of power and as coalition partners in the establishment process of a particular scheme vis-à-vis their competitors.

This thesis claims that, despite what is often claimed, state actors play a crucial role in forest certification and related politics (Cashore et al. 2004, Gale and Haward 2011, Bartley 2014, Gulbrandsen 2014) by either obstructing (Gulbrandsen 2010; Gale and Haward 2011, Gulbrandsen 2014, Sahide et al. 2015) or supporting competing certification initiatives (Hysing 2009, Bell and Hindmoor 2012).

\subsection{Pathways of influence used by international and transnational organizations}

Current governing arrangements are no longer represented by single-issue regimes with states as only actors, but rather by a mixture of mechanisms including legal, non-legal, governmental and nongovernmental arrangements (Bernstein and Cashore 2012). The way these complex international regimes may exert their influence at the domestic level can be categorized into "four pathways of influence, each with its own causal logic: international rules (the traditional focus of regime effectiveness literature); international norms and discourse; creation of or interventions in markets; and direct access to domestic policy processes" (Bernstein and Cashore 2012, 587). The international rules pathway refers to binding international treaties, trade agreements or policies of powerful international organizations; the international norms and discourse pathway refers to non-binding norms and discourse by means of information, symbolism and accountability; the creation of or interventions in markets pathway refers to the use of markets to make domestic policy changes; the direct access pathway refers to the influence by means of direct funding, education, training, assistance and capacity-building (Bernstein and Cashore 2000, 2012). 
Previous studies on the implementation of the international forest regime complex at the national level have analysed how relevant international influences are on domestic forest policy change in different countries through the four pathways of influence from global governance (Bernstein and Cashore 2012). While some studies focused on only one pathway of influence, as Gale and Cadman (2014) who analysed how the international norms and discourse pathway through the concept of sustainable forest management and the resulting Montreal process was implemented in Canada following the interests of domestic actors and their networks; and Cashore and Stone (2012) who analysed the influence of market mechanisms as forest certification and timber legality verification systems in South East Asia. Other studies have tried to explain how international influences occur through the four pathways. Lindstad (2015) analysed international influences on the changes in forest protection and forest-related climate policies in Norway through the four pathways of influence, Wibowo (2015) analysed the domestic consequences of international influences in REDD+, one map and forest certification politics in Indonesia. Arts et al. (2013) analysed influences from the global and European Union level to domestic policy processes in Europe observing that the direct access pathway was not very relevant in European countries.

In this thesis the theorem of pathways of influence is used to analyse how international and transnational organizations promote forest policy change at the domestic level. Especially, the direct access (Burns and Giessen 2016, Burns et al. unpublished) and the creation of or intervention in markets (Burns et al. 2016) pathways are used. While Bernstein and Cashore (2012) propose that international norms and discourse is a stand-alone pathway, this thesis proposes this is not necessarily a distinct pathway of influence as the other three but rather a pre-stage preparing the way for any of the other three pathways of influence to occur (Burns and Giessen 2016, Burns et al. unpublished). This goes in line with Arts and Buizer (2009) who claim that sustainability and governance discourses are institutionalised in global forest policy over time. As an example, discourse at international level introducing the concept of "sustainable forest management (SFM)" gave way to the creation of markets pathway by means of forest certification schemes to promote SFM (cf. Hogl et al. 2009).

\subsection{Domestic actors and bureaucratic politics theory}

In order for international and transnational regimes to become influential and to impact on domestic policies, a specific actor has to take agency (Biermann et al. 2009). These actors can be either state or non-state. Domestic state actors are defined as domestic bureaucracies. A bureaucracy can be defined as

"an agency that has been set up by governments or other public actors with some degree of permanence and coherence and beyond formal direct control of single national governments" (Biermann et al. 2009, 37). Bureaucratic politics theory claims that bureaucracies compete with each other for resources, staff and responsibility for policy domains. Resulting public policy is strongly shaped by this competition between bureaucracies with different preferences, abilities and power capabilities (Krott 2005, Peters 2010, Giessen et al. 2014). In their struggle for power, bureaucracies act in coalition with other public and private actors in fields where their interests (partly) overlap, trying to establish institutions in support of this shared interest. Being rather stable over time, this combination of shared interests and institutions is referred to as a policy sector, e.g., forestry or agriculture (Rayner et al. 2001). In joining forces, policy sectors attempt to influence public policy based on the overlapping portions of their interests. 
In forest related international negotiations domestic bureaucracies compete to represent their countries in international forest negotiations (Hogl et al. 2009, Edwards and Kleinschmit 2013, Giessen et al. 2014). According to Giessen et al. (2014) the bureaucracies which may have an active role in the international forest regime complex and its implementation are: agriculture (including forestry), environment, hybrid between agriculture and environment, foreign affairs, and economics and trade. Based on their tasks and responsibilities, the main line of conflicts runs between conservation-oriented bureaucracies as the ministries of environment and the utilitarian bureaucracies as the ministries of agriculture and forestry (Humphreys 2006, Giessen et al. 2014). The fragmentation of the international forest regime complex leads to the possibility of different bureaucracies to be in charge of different issues within the regime complex (Giessen et al. 2014). Giessen et al. (2014) used bureaucratic politics theory to show an increase in responsibility of utilitarian bureaucracies over more conservation-oriented bureaucracies in different issues within the international forest regime complex.

Following the core theses of bureaucratic politics theory this thesis theorizes that forest-related bureaucracies use international and transnational regimes as means to increase their power in their permanent competition for resources, staff and responsibility for policy domains.

\subsection{Power theory}

According to previous studies, the power of the different political actors is one of the most important factors explaining forest governance (Agrawal et al. 2008, Brockhaus et al. 2012, Krott et al. 2014). Actorcentred power can be defined as "a social relationship in which actor A alters the behaviour of actor B without recognising B's will" (Krott et al. 2014, 37). Actors have different power sources that they use to produce policy change and increase their influence in the policy making process. These power sources comprise three elements: coercion, incentives and non-verified information (Krott et al. 2014). Coercion is defined as altering the behavior of an actor by force, (dis)incentives are defined as advantages and disadvantages introduced to alter the behavior of an actor, and dominant information is defined as unverifiable information that makes the decision process more difficult for actors (Krott et al. 2014).

This actor-centred power theory has been developed using community forestry as an illustrative case (Krott et al. 2014, Giessen and Buttoud 2014). While the theory has already been applied in many community forestry studies across many countries (Devkota 2010, Maryudi et al. 2012, Yufani Movuh and Schusser 2012, Schusser 2013, Schusser et al. 2015), lately it has also been used in studies on the implementation of the international forest regime complex at national level (Brockhaus et al. 2014, Mohammed and Inoue 2014, Wibowo and Giessen 2015).

In this thesis we use the actor-centred power theory combined with bureaucratic politics theory. Bureaucracies, as actors have different sources of power that they use to increase their influence in the forest policy making process. Following this theory the main sources of bureaucracies' power based on coercion are their legal mandates (including decision rights and sanction mechanisms), technical resources (enabling bureaucracies to maintain a policy process) and alliances between bureaucracies and external actors putting pressure behind the preferences of a bureaucracy. The main sources of power based on incentives are transfer funds, creating a link to other issues and funds for setting incentives for others to follow their preferences and alliances between bureaucracies and external actors putting resources behind the preferences of a bureaucracy. The main sources of power based on selected infor- 
mation are the bureaucracies' expertise and active selection of information as well as interest-guided use of beliefs and values (Krott et al. 2014).

\subsection{Federalism and forests}

Federalism can be defined as "a sort of association or league of sovereign states with separate, selfsustaining centres of power and prestige" (Ellefson et al. 2006, 653). This division in power between higher and lower levels of government leads to competition for influence on the policy making process not only between national bureaucracies but also between national and subnational bureaucracies. Domestic bureaucracies may use international issues to strengthen their positions vis-à-vis competing agencies, both at the national as well as the provincial level, by taking up issues, discourses and norms to legitimize their roles as well as by finding domestic or international coalition partners (Bernstein and Cashore 2012, Giessen 2013, Wibowo and Giessen 2015). In federal systems of governance, international issues shift the power balance towards national bureaucracies, even in issues that are actually within the provincial domain (Hofmann 2002, Scharpf 2006). As a response to this shift in power balance, subnational bureaucracies try to get involved in international issues as well. How they will pursue this depends on how responsibilities regarding a certain issue are vertically distributed between the national and subnational governments (Lopreite 2014) but national bureaucracies will remain in a better position. In cases where subnational bureaucracies have the competency over certain issues they might be stronger than in issues of national competences (Lopreite 2014). Federal constitutions granting the subnational level with full regulatory power can obstruct negotiations and implementation of international regimes since national government might not be able to bind subnational governments (Hudson 2012).

While in international forest governance decentralization mechanisms have been previously studied (e.g. Larson 2003, Palmer and Engel 2007, Nathan and Boon 2012, Sahide et al. 2016) the effects of federalism have so far not been analyzed with only few exceptions (Hofmann 2002, Ellefson et al. 2006, Hudson and Weinthal 2009, Hudson 2012). The United States is an example of the importance of federalism in the implementation of any international forest agreement, since the federal government would be unable to implement any forest management practices due to constitutional constrains (Hudson and Weinthal 2009, Hudson 2012).

This thesis takes as point of departure this important gap in forest policy research and tries to explain how federalism might explain the role different actors play in the forest governance process, especially regarding competition between national and subnational bureaucracies and coalition building with international and transnational organizations

Against this theoretical background this thesis proposes the following hypotheses:

Hypothesis 1. Elements of the International Forest Regime Complex are made relevant at the domestic level by specific actors. In particular it is the interests of the most powerful actors that determine which forest issue elements become relevant at the domestic level.

Hypothesis 2. International organizations like the World Bank influence national forest policy by the provision of funding and capacity building. In addition to providing resources international organizations 
gain power by building coalitions with national bureaucracies in order to be able to influence domestic policy.

Hypothesis 3. With the formal goal of enhancing the contribution of the forests to public goods, the World Bank supports market-based conversion of the national forest sector and pushes institutional structures towards deregulation. However, informally, the administrative reform leads to a weak bureaucratic structure unable to implement new policies which are aimed to protect public goods in the forests against side effects of the market driven uses.

Hypothesis 4. Although it is often claimed that transnational regimes network only private actors, in practice state bureaucracies play an important role. In forest certification, international actors seek coalitions with different state bureaucracies.

Hypothesis 5. In federal countries, international and transnational forest regimes influence domestic forest policy by changing the power balance of the domestic networks. International allies help nationallevel bureaucracies to gain relative power over the provincial-level bureaucracies. 


\section{Methodology}

\subsection{Case description}

In order to obtain empirical rich evidence for testing the hypothesis two cases with strong political dynamics in the forest sector and strong intervention by the World Bank and with additionally good field access were needed. Following these criteria Argentina and Armenia were selected as case studies. In Argentina the author has good access to the field and rich personal experience. In Armenia cooperation with an experienced senior scientist visiting our Institute in Göttingen where he got familiar with political theory and methods in social sciences provided good field access.

\section{Argentina}

Argentina has a continental area of $2,791,810 \mathrm{~km}^{2}$, with a length from north to south of $3,700 \mathrm{~km}$ between $22^{\circ}$ and $55^{\circ}$ of Latitude South. This extension determines a wide climatic variation, from subtropical conditions in the north with mean annual temperatures above $20^{\circ} \mathrm{C}$ to temperate conditions in the south with mean annual temperatures below $10{ }^{\circ} \mathrm{C}$ (SAyDS 2010a). In the country there are around 31.4 million hectares of natural forests divided into six ecological regions (SAyDS 2005). Moreover, there are 1.2 million hectares of cultivated forests, $80 \%$ of which are located in the northeast of the country, in the Mesopotamian region (MAGyP 2013). Argentina adopted a federal republican representative form of government. Except for national parks, which are under the jurisdiction of the national government, forests toile within the political responsibility of the provinces and are subject to provincial laws under the umbrella of national laws (Article 124 of the National Constitution 1994). At a national level, the Secretariat of Environment and Sustainable Development is responsible for natural forests, while the Ministry of Agriculture, Livestock and Fisheries is responsible for forest plantations. Forests are mainly owned privately: $99.7 \%$ of plantation forests and $93.5 \%$ of natural forests are privately owned (Burns and Giessen 2014).

In the early 1990s, in the middle of an economic crisis, a strong coalition of (agricultural and profitoriented) bureaucracies and associations of private landowners (in forestry as well as agriculture) emerged, advocating for more profitable and productive land uses with subsequent supporting policies and administrative frameworks (Burns and Giessen 2016). At this time, international actors as the FAO and the World Bank played a crucial role supporting the domestic coalition of pro-agriculture public and private actors. As a consequence, the Argentine National Forestry Institute (IFONA), a strong and comprehensive forest bureaucracy, was dismantled into four weaker bureaucracies (Burns and Giessen 2016). By forming coalitions with the World Bank, some of the newly created bureaucracies were able to increase their power (Burns and Giessen 2016). The administrative reform and policy changes carried out with funding and a high level of political support provided by the World Bank led to increased investments in the forestry sector, mainly by international firms, especially from Chile (between 1992 and 2013, 66\% of the total investments in the forestry sector was done by Chilean companies with three Chilean forestry firms dominating Argentina's forest holdings and wood exports) (Espach 2005, Burns and Giessen 2016).

As part of the political changes taking place in the beginning of the 1990s the National Constitution was reformed in 1994. With this reform, province's sovereignty over their natural resources was stated clear- 
ly giving the provinces the right to legislate on forest issues within their territory. This makes the subnational bureaucracies involved in the forest sector important actors and potential coalition partners. However, with the new government that took over after the 2001 crisis, the national government increased their power vis-à-vis the provinces by means of new sources of revenue that were not shared between the federal and provincial governments, decreasing provinces' share of overall revenue and increasing provincial governments' dependence on the federal government (Levitsky and Murillo 2008).

The above mentioned characteristics make Argentina an interesting case to analyze coalition options between strong private actors as landowners and national and subnational state bureaucracies. The World Bank intervention in the forest policy reform provides a good case to analyze coalition building between domestic and international actors. Between 2001 and 2002, Argentina began the development of forest certification processes, both FSC and PEFC. These processes continued until the year 2014 with the development of standards, providing an appropriate case for studying the role of different state actors, both national and subnational, and the coalitions made, in the development of forest certification schemes.

\section{Armenia}

The Republic of Armenia, located in the southern Caucasus, has a total area of $29,800 \mathrm{~km}^{2}$ within 11 provinces. In 1828, the country was incorporated into Russia and later, in 1920, into the United Soviet Socialist Republics (USSR). Armenia achieved its independence when the USSR was disintegrated in 1991, in the middle of a war against Azerbaijan over Nagorno-Karabakh that lasted between 1988 and 1994. As a result of this war, and together with a devastating earthquake in 1988, the country ended up in severe economic and environmental damage, leading to political violence together with transport, economic and energy blockades (Sayadyan and Moreno-Sanchez 2006). This situation caused great pressure on the forests and other natural resources resulting in soil erosion, high deforestation rates and biodiversity loss (Sayadyan and Moreno-Sanchez 2006). Due to its location as well as its topographic complexity, forests in Armenia have a high percentage of plant and animal endemism, and are included in the Caucasus and Irano-Anatolian biodiversity hotspots (Sayadyan and Moreno-Sanchez 2006). By the year 1992, the total forest cover of Armenia was almost 460,000 ha, with about $11.2 \%$ of the country being wooded vegetation (Sayadyan and Moreno-Sanchez 2006). Since the Soviet period all forests are state owned and managed only for conservation and protection, according to the 1978 USSR Forestry Code which divided all forests into three categories, classifying all Armenian forests into Group I (protected forests) allowing only sanitary and reproductive cuts (Sayadyan and Moreno-Sanchez 2006). After independence, a new Armenian Forestry Code was published in 1994 based on the 1978 Soviet Forestry Code, again declaring all forests as state owned and reserved for protection and conservation (Sayadyan and Moreno-Sanchez 2006). In 1995, a new bureaucracy, Armforest State Forest Enterprise (Hayantar), in charge of forest management, was created under the Ministry of Nature Protection (Sayadyan and Moreno-Sanchez 2006). At the same time, a new national forest policy aiming to make economic use of the forest was proposed, but this was never approved (Sayadyan and Moreno-Sanchez 2006). In 1998, the Forest Research Experimental Center (FREC) was created, also under the Ministry of Nature Protection, with the aim of forest monitoring and inventorying. However, coordination between these two forest-related bureaucracies was never achieved (Sayadyan and Moreno-Sanchez 2006). This lack of coordination and 
capacity of the forest bureaucracies, together with a high demand of forest products caused by the lack of imports from Russia, led to an increase in illegal logging of the forests (Sayadyan and Moreno-Sanchez 2006). At this time, the economy began to recover, with stabilization and structural reforms driving a liberalization of the economy, small and medium privatizations and the formulation of a legal administrative framework for market economy. The Ministry of Nature Protection then invited the World Bank to assist them in the establishment of a new forest policy under the principles of sustainable forest management. This invitation led to the formulation of the "Armenian natural resources management and poverty alleviation" project with funding from both the World Bank and the Global Environment Facility (GEF). Summing up Armenia is a perfect case with dynamic forest policy and strong intervention by the World Bank.

\subsection{Empirical methods}

\section{Data collection}

All articles constituting this thesis focused on two main sources of data: written documents and semistructured interviews with experts. Written sources were distinguished between public and expert sources. The distinction between these two types of sources lies on the degree of publicity. Public sources were defined as all material accessible to the whole population including newspapers and websites. Expert sources were defined as all material focused on a selected audience from the forest sector. The selection of the interviewees was based on their knowledge of the forest sector as well as on ease of field access. In order to include diversity of viewpoints and interests, especial attention was given to interview both private and state actors from conservation and production oriented sectors. Interviews were carried out in Spanish in the case of Argentina and English in the case of Armenia. Additional interviews were carried out in Armenian by a local collaborator. Interviews lasted between half an hour and two hours. If it was not possible to meet with the interviewees in person, they were contacted by phone calls or emails. In all cases, interviewees were granted confidentiality in order to ensure full disclosure (Koontz and Newig 2014). Data was used for the triangulation between documentary sources and all of the interviews, ensuring its validity and reliability, mainly using interviews as an initial indicator of the main issues and positions (Singer 2009, Koontz and Newig 2014, Lorenzoni and Benson 2014). If there were contradictions or differences in interpretation, priority was given to written records (Davies 2001).

In total approximately 60 interviews were carried out, 50 in Argentina and 10 in Armenia between October 2012 and September 2014. In addition around 150 documents from both public and expert sources were analyzed in the same time period.

\section{Process tracing}

The method of process tracing "attempts to trace the links between possible causes and observed outcomes" (George and Bennett 2005, 6), focusing on sequential processes within a particular case. By providing theory-based historical explanations for a case in which each significant step toward the outcome is explained by referring to a theory, process tracing becomes a powerful method of inference (George and Bennett 2005, 30). Each process tracing account proposes evidence to be found in case the account is true. While some evidence could explain more than one alternative there is evidence that can 
only be found in case the proposed theory is true, when more of the latter type of evidence is found the stronger the process tracing account (Bennett and Elman 2006).

Process tracing has been widely used as a fundamental tool of qualitative analysis in international relations and public policy analysis (Collier 2011). In the specific case of environmental and forest policy analysis process tracing has been used in transnational environmental governance to study the mechanisms of influence of forest and fisheries certification (Gulbrandsen 2010) as well as the emergence and institutionalization of legality verification as a means to address global forest degradation (Cashore and Stone 2014).

In this thesis process tracing was used to understand how international and transnational organizations influence policy change in the domestic level through direct access and market mechanisms. To do so the cases of the World Bank-funded forest projects and forest policymaking in Argentina from 1991 to the present, the World Bank-funded natural resources management and poverty alleviation projects and forest policy making in Armenia from independence to the present and the development of two competing forest certification schemes in Argentina from 2001, when forest certification was first put in the political agenda in the country, to the present were selected. In all cases data was collected from different sources and analyzed by means of qualitative content analysis.

\section{Qualitative content analysis}

Qualitative content analysis is a flexible method for analyzing text data (Hsieh and Shannon 2005, Neuman 2005). This method focuses on the language as a means of communicating with attention to the content of a text (Hsieh and Shannon 2005, Neuman 2005). This method has been widely used in political sciences to analyze documents and interviews since it is the most appropriate method for revealing in an objective way the most significant text, word or symbol from a large volume of text (Neuman 2005). The large quantities of text that is analyzed requires that is organized into fewer content categories. This translation from data into categories is defined as coding (Fabra-Crespo and Rojas-Briales 2015)

Qualitative content analysis has been widely used in forest policy analysis. Some recent examples of qualitative content analysis in forest policy analysis are studies on media reporting about forest issues as well as biodiversity (Sadath et al. 2013, Fabra-Crespo and Rojas-Briales 2015), studies on REDD+ and drivers of deforestation (Wehkamp et al. 2015, Fischer et al. 2016) and studies on the implementation of the international forest regime (Wibowo and Giessen 2015, Sahide et al. 2015; 2016).

In this thesis qualitative content analysis was used in all constitutive articles to analyze all data. In order to identify the most relevant international forest issues in Argentina, this method was used in a two stage approach, distinguishing between public and expert sources in both stages. For the public sources, the first stage consisted of an open search in a broadly distributed national newspaper (La Nación) that was selected for eliciting the relevant issues. The terms "international", "forest" and "forestry" were searched with the search engine of the newspaper between the years 2008 - 2012. For the expert sources, an open search on professional journals in the field of forestry (Argentina Forestal, Producción Forestal) was done. The second stage, after main actors and issues were identified, included a more focused search. For public sources, websites and position papers of the different actors towards the identi- 
fied issues were searched. For expert sources, interviews to people with broad knowledge of the forest sector in Argentina were made. To each one of them a question was made: Which international forest policy issues were relevant in Argentina between the years 2008 - 2012? Interviews were used as an additional source to verify the data from other. In the analysis, forest-relevant actors were coded according to Krott (2005) into forest users (forest owners, forest workers and employees, general population), associations and parties (forestry associations, environmental NGOs) and government and administration bureaucracies.

In the cases of the World Bank intervention in forest and natural resources policy change in Armenia a documented search of publicly available World Bank proposal documents and project completion reports was done as a first step. Using these documents the executive bureaucracies involved in the projects were identified. Websites of these bureaucracies were then reviewed to obtain published outputs of the projects. Subsequently semi-structured interviews with experts were conducted about the role and influence of international actors and domestic state and non-state actors in the process. Qualitative content analysis was then used to analyze all documents and interviews. The information obtained from the different data sources was then coded and grouped into four main categories, based on the research objectives. These categories were (i) administrative structure, (ii) policy content, (iii) project formulation, and (iv) project implementation.

Qualitative content analysis was also used to analyze all documents and interviews for revealing the role of state agencies in the institution and the setup and operation of two forest certification schemes (FSC and PEFC) and their standards in Argentina. 


\section{Results}

\subsection{Relevance of the International Forest Regime Complex by powerful actors}

When analyzing the implementation of the International Forest Regime Complex in Argentina, Burns and Giessen (2014) found that seven different forest issue elements were made relevant at the national level by different actors. These issues were climate change and forests, forest biodiversity, regional policy initiatives, competing forest certification schemes, desertification and forests, bilateral forest related disputes and support by international organizations (Burns and Giessen 2014). The issues detected in Argentina were not the same as the relevant subjects found in similar studies conducted in Indonesia (Wibowo and Giessen 2015) and Bangladesh (Rahman and Giessen 2014) although some similarities were observed. While in all three cases climate change was a relevant issue, forest certification was only detected as an issue in Argentina and Indonesia being absent in Bangladesh. Similarly, forest biodiversity was observed as an issue in Argentina and Bangladesh but absent in Indonesia (Burns and Giessen 2014, Rahman and Giessen 2014, Wibowo and Giessen 2015).

Which issues become relevant in different countries depends on the domestic actors and their interests. In order to become influential, a political issue needs to be put on the agenda (Howlett and Ramesh 1995). In the politics surrounding the issue, a number of actors concerned will then take positions based on their interests (Krott 2005, Burns and Giessen 2014, Wibowo and Giessen 2015). This was observed in Argentina, where Burns and Giessen (2014) identified the main actors and their positions towards the main forest issues. As a result they found that based on the amount of issues each actor had a public position on, environmental NGOs were the most active actors. However, based on the role played in the implementation of the issues, the authors found that the Secretariat of Environment and Sustainable Development was the most relevant actor by being involved in the implementation of all issues detected (Burns and Giessen 2014). This result shows the significance of main bureaucracies in dealing with international forest issues in Argentina as suggested by the bureaucratic politics theory (Peters 2010). According to this theory, only a single actor has a dominant role in a particular sector, however, Burns and Giessen (2014) found that in some issues like desertification and forests and forest certification both, the Secretariat of Environment and Sustainable Development and the Ministry of Agriculture, Livestock and Fisheries seem to work together. Similar results were found in Indonesia (Wibowo and Giessen 2015) and in Bangladesh (Rahman and Giessen 2014). However, although based on their public positions these two bureaucracies showed similar interests, when ongoing politics were analyzed a different situation was observed (Burns and Giessen 2016, Burns et al. 2016).

In the case of forest certification, while in a first stage both, the Secretariat of Environment and Sustainable Development and the Ministry of Agriculture, Livestock and Fisheries supported the creation of FSC national standards through informational instruments as well as the provision of staff being involved in the negotiation of the standards, their positions changed as soon as the development of a competing system, PEFC, started (Burns et al. 2016). By refusing to take part in the association that administers PEFC in Argentina, the Secretariat of Environment and Sustainable Development shows their lack of support for this system in the country. Opposite behavior was observed from the Ministry of Agriculture, Livestock and Fisheries who not only takes part in the governing body of PEFC in Argentina but also financed the endorsement of the national standard to PEFC (Burns et al. 2016). The support to the devel- 
opment of a national standard for PEFC provided by the Ministry of Agriculture, Livestock and Fisheries in coalition with the three national forest associations, i.e. the Argentine Forest Association (AFoA), the Argentina Federation of Wood and Allied Industries (FAIMA) and the Cellulose and Paper Manufacturers Association (AFCP) led to the success of the process, which in 2014 acquired the mutual recognition of PEFC. On the other hand, the FSC initiative with the support from environmental NGOs and the Secretariat of Environment and Sustainable Development has not yet succeeded in the development of a national standard (Burns et al. 2016). This case supports our hypothesis that while the opposing public positions of different actors towards an issue determine which issues are made relevant in a country, it is the interest of the most powerful actors that determine which issues are actively implemented and how.

A similar situation was observed in the case of forest biodiversity in Argentina identified as one of the main forest issue elements with support from all environmental NGOs as well as from the Secretariat of Environment and Sustainable Development (Burns and Giessen 2014). This support led to the approval of the Convention on Biological Diversity (CBD) by a national law and the establishment of a committee within the Secretariat of Environment and Sustainable Development to follow up the convention developing a national strategy about biological diversity. However, Argentina has not approved the Cartagena Protocol on Biosafety. An explanation for this decision can be found in the fact that Argentina is one of the main world producers of genetically modified organisms, ranking second in the world in 2006. Therefore, most private agricultural sectors, opposed the ratification of this Protocol (Burns and Giessen 2014). In this case, the same as with the case of forest certification, it was the interests of the most powerful actors, in this case the private agricultural sector in coalition with the Ministry of Agriculture which determine which issues are implemented at the national level.

While the public position towards an issue and the conflicting interests of different actors make an issue relevant and visible empirically, the issues which are not made relevant and the reason why they are not made relevant cannot be detected by analyzing the position of the different actors. In the case of Argentina this was observed by Burns and Giessen (2014) when identifying the most relevant forest issue elements in the country. The analysis carried out by the authors did not identify deforestation and soy bean expansion as an international forest related issue despite its importance (Pengue 2005, Leguizamón 2013, Burns and Giessen 2016). The explicit blocking of certain issues, especially by powerful actors, from the international forest regime complex at the domestic level should also be analyzed in order to understand the implementation of the regime.

In the analysis of forest-relevant actors and their positions towards different issues from the international forest regime complex in Argentina actors were classified according to Krott (2005) into forest users (forest owners, forest workers and employees, general population), associations and parties (forestry associations, environmental NGOs) and government and administration bureaucracies (Burns and Giessen 2014). However, this analysis and classification of actors was blind to the role of powerful international organizations as the World Bank. Although their analysis identified the support by international organizations in forest-related initiatives as an issue, the World Bank was not identified as an actor. However, Burns and Giessen (2016) showed the important role this international organization had in forest policy change in the country. 


\subsection{The World Bank and domestic forest policy}

In a study that aimed to analyze the influence the World Bank exerted on domestic forest policymaking and bureaucratic reform in Argentina, Burns and Giessen (2016) found that by means of funding and capacity building, the World Bank, as an international organization, assisted the coalition of agricultural and profit-oriented bureaucracies and landowner associations (of forestry and agriculture) that emerged after the economic crisis in the country at the beginning of the 1990s. The intervention of the World Bank in the reform of forest policy in Argentina figured prominently in the form of new forest laws that, as a whole, benefited plantation forests and opened land for agricultural production (Burns and Giessen 2016). This supports our hypothesis that international organizations like the World Bank try to influence forest policy by the provision of funding and capacity building to produce domestic policy change. However, in order to become influential at the national level such international organizations as the World Bank need an invitation from a domestic bureaucracy due to sovereignty principles. In the case of Argentina, national forest bureaucracies who have been weakened in relation to strong and emerging agricultural bureaucracies sought assistance through funding from the World Bank. As a result of this assistance the bureaucracies of both native forests and plantation forests were able to increase their power, at least in the short term.

After the Argentine National Forestry Institute (IFONA), a comprehensive and autonomous bureaucracy responsible for all aspects of forests at a national level was dismantled accused of inefficiency and corruption, the Directorate for Native Forests, within the Secretariat of Environment, became the weakest forest bureaucracy in Argentina but gained power later. By forming a coalition with the World Bank, and with the support of environmental NGOs the Directorate wrote a new forest law (Law 26331). This Law granted this bureaucracy permanent funding from the national budget, which allowed it to double its staff after two years of implementation. In addition, this bureaucracy produced the first native forest inventory, in coalition with the World Bank, creating a new unit within the Directorate that would be in charge of the inventory and of monitoring the forest cover. The information produced with this inventory was of great utility for this bureaucracy at the time of implementation of the new law and of great importance for the agricultural policy sector, since it strived to gather information on forests that could be transformed into agricultural uses. These results are in line with the theory proposed by Bernstein and Cashore (2012) that states that influence from international bureaucracies through the provision of funding resources could shift the power balance in domestic policy processes, benefitting marginalized or disempowered bureaucracies. Weak bureaucracies, seeking to increase their power, invite and allow international bureaucracies to influence the policy-making process. Bernstein and Cashore (2012) also propose that, by helping domestic bureaucracies enforce or implement their own laws by means of direct access, international organizations are more likely to succeed than by passing new legislation. Our results show that, in the Argentinian case, the World Bank was an ally in the formulation and implementation of new laws. However, these laws were in accordance with the requirements of domestic agriculture bureaucracies and of broader agricultural interests, as Bernstein and Cashore (2012) suggest.

Because domestic bureaucracies like the Secretariat of Agriculture and the Secretariat of Natural Resources were in permanent competition, they invited the World Bank with the aim of increasing their domestic power at the cost of their domestic competitors. This invitation led to the establishment of influence through direct access of the World Bank on domestic forest policy and administration (Burns 
and Giessen 2016). This supports our hypothesis that in addition to providing resources, international organizations like the World Bank need to build coalitions with national bureaucracies in order to be able to produce policy changes. By providing funding and capacity building they assist the existing domestic coalitions of bureaucracies and associations in their constant competition for power, or help create new ones.

In a similar study conducted in Armenia, Burns et al. (unpublished) found that World Bank interventions aiming to reduce rural poverty by means of improving natural resources management also led to policy and administrative changes. As a result of the reform promoted by the World Bank through direct access by means of incentives power in this country the forest administration was restructured and new legislation creating private forests approved (Burns et al. unpublished). This came together with a change in forest management, away from pure conservation goals and towards production use of the forests. Along this change, the forest administration, which used to be under the Ministry of Nature Protection, was moved to the Ministry of Agriculture. As observed in the case of Argentina, the forest administration in Armenia increased its budget. However, this administration saw a reduction in policy domain, since control activities were given to the Ministry of Nature Protection, who also kept forest inventory and planning responsibilities. As a consequence, the forest bureaucratic structure reform promoted by the World Bank led to the fragmentation of the forest policy domain with weakened forest bureaucracies but with increased budgets, at least during the duration of the project (Burns et al. unpublished). These results are in line with the findings from the forest sector reform in Argentina, where funding from the World Bank led to the dismantling of an autonomous forest bureaucracy into four different units within different ministries (Burns and Giessen 2016). Similar findings were observed with the forest sector reform in Mali where also as a result of the World Bank intervention the National Forest Administration lost its power, losing responsibilities and budget. In this case, the forest bureaucracy was not dismantled and fragmented like in Argentina and Armenia but weakened by the World Bank promoting the devolution of forest management to the local level and to a newly created bureaucracy funded by the World Bank, responsible for creating efficient markets (Gautier et al. 2013).

The World Bank, as an international organization, has assisted more than 50 developing countries in the development of their environmental, legal, and institutional capacities (Marschinski and Behrle 2009). Similar patterns of change as the ones observed in Argentina and Armenia were observed in Mali (Gautier et al. 2013), Cameroon (Singer 2009), Brazil (Lele et al. 2000), and Lithuania (Brukas and Hjorts $\varnothing$ 2004), among others. In all these cases, the World Bank compensated bureaucracies for their loss in power by means of incentive power.

These results support our hypothesis that for the World Bank to become influential in domestic forest policy they need to build coalitions with national bureaucracies by providing funding and capacity building that national bureaucracies use to get more power resources in their constant competition with other bureaucracies.

\subsection{The World Bank leading to deregulation and weak bureaucratic structures}

The influence of the World Bank in Argentina and Armenia through direct access by funding projects aiming at poverty alleviation and sustainable natural resources management pushed the forest sector towards deregulation (Burns and Giessen 2016, Burns et al. unpublished). In both cases funding by the 
World Bank started after neoliberal reforms were taken in the political economy of the countries. Neoliberalism is one of the most influential discourses of our time, which gained strength as a normative discourse in the 1980s after the US and UK adopted neoliberal policies (Humphreys 2009). The World Bank and the International Monetary Fund have promoted neoliberal ideas like trade liberalization, privatization and deregulation in many developing countries (Humphreys 2009). In Argentina, in the 1990s, the new neoliberal discourse paved the way for the coalition of agricultural interests, together with the World Bank, to influence forest policy and administration structure, through direct access (Burns and Giessen 2016). A same process was observed in Armenia where, following a big economic crisis which started after achieving independence when the United Soviet Socialist Republics (USSR) was disintegrated in 1991, structural reforms were applied driving a liberalization of the economy, small and medium privatizations and the formulation of a legal administrative framework for market economy. These market-friendly economic reforms, as observed in Argentina, received important support from the World Bank (Burns et al. unpublished). However, in post-socialist countries, as the case of Armenia the implementation of these reforms was especially challenging due to the previous system of complete state control, with limited private property and centralized administrative systems (Otto and Chobotová 2013). During the transformation process that started after the Cold War, World Bank lending to postsoviet countries went to those undertaking big Structural Adjustment Programmes aiming to eradicate poverty by promoting sustainable social and political changes together with economic reforms (Davies and Woodward 2014), as was observed in the case of Armenia (Burns et al. unpublished). Such structural adjustment lending provided economic incentives to economic sectors, such as forestry and agriculture, to restructure government activity, shift activities to the private sector and downsize bureaucracies (Davies and Woodward 2014, 254).

Following a framework of neoliberal conservation governance, promoting market-based mechanisms that aim to motivate local users to address environmental concerns by means of incentives, the World Bank promoted the intensification of natural resources production both in the case of Argentina and Armenia. Although seen as a fundamental step towards sustainability, these neoliberal conservation policies have been criticized for informally promoting decentralization, privatization and commodification that allow corporations and international actors to increase their influence over local natural resources (Levine 2002, Fletcher 2010, Roth and Dressler 2012).

As a result of the World Bank intervention, both in Argentina and Armenia, new forest laws were approved. These new laws implied a change towards production use of the forests and away from conservation. In the case of Armenia, the new Forest Code established that forests and forest lands can be under state, community and private ownership. This change allowed privatization of lands in cases where land users would afforest or reforest. Until this change, according to the previous Forest Code, land was all state owned. The Code also introduced the category of forests of production significance where wood production activities are allowed, with the approval of forest management plans. This new category of forests produced a changed towards an economic use of the forest from a pure conservation aim (Burns et al unpublished). Legislation and regulations dealing with biodiversity conservation in protected areas were also changed as a result of the influence of the World Bank. In this case a new law on Specially Protected Natural Areas was adopted allowing protected area administrations to generate and retain income (Burns et al. unpublished). The same changes were observed in Argentina where a new forest law 
(National Law 26331) that formally promotes the conservation of native forests through land-use planning was approved as result of the intervention of the World Bank (Burns and Giessen 2016). This Law establishes three conservation categories for the native forests: Category I (red) includes high conservation value areas where no forest management is allowed; category II (yellow) is made up of medium conservation value areas subject to forest management with an approved sustainable forest management plan; and category III (green) comprises areas of low conservation value that can be converted into other land uses, like agriculture (similar Gartland 2012, Romero 2012). While it provides ample leeway for promoting agriculture at the cost of native forests, the law requires the planning of provincial native forestland use to be based on a participatory process that includes actors from outside the forest sector. Hence, strong policy sectors, like agriculture, were able to exert great influence on the results of the categorizations. As a result, this law opened the way to land use changes in the green areas, where native forests could now be converted into any one of other land uses, like agriculture, which provide provinces higher returns than the compensation received through conservation in red areas (Burns and Giessen 2016).

By funding projects with the formal aims of promoting sustainable natural resources management under the framework of neoliberal conservation governance the World Bank also promoted an administrative reform of the forest sector. Burns and Giessen (2016) found that in the case of Argentina, this reform of the forest sector led to the fragmentation and weakening of national forest bureaucracies in relation to strong and emerging agricultural bureaucracies. The dismantling of IFONA which led to the separation of native and plantation forests, including plantation forests in the Secretariat of Agriculture, is in line with the empowerment of the agriculture sector. Although the newly created Directorate for Native Forests was able to increase its power due to its coalition with the World Bank, it still represents a reduction in scale, from an autonomous forest bureaucracy to one unit within a secretariat of environment. In Armenia, similar results were observed by Burns et al. (unpublished). Although in this case the forestry administration was not dismantled as in Argentina, it was moved from the Ministry of Nature Protection to the Ministry of Agriculture. This change was in line with the changes in forest management objectives towards production forests. Following the structural change carried out with support from the World Bank, the responsibility for control was taken away from the forest administration and given to the Ministry of Nature Protection, except for illegal logging controls that were kept under the responsibility of the forest administration. Control functions were then given to three organizations, the Forest State Monitoring Centre (FSMC), the newly created State Forest Service (SFS) and the State Environment Inspectorate (SEI), all within the Ministry of Nature Protection. This overlap between different administrations weakens the control activities (Elmqvist and Rylander 2010). These results are in line with findings from the forest sector reform in Mali, where funding from the World Bank also resulted in a weakening of forest bureaucracies (Gautier et al. 2013).

Our results support our hypothesis that despite the formal goal of sustainability and forest conservation, the World Bank supports market-based conversion of the national forest sector and pushes institutional structures towards deregulation. As a result there is a decline in power of forest bureaucracies leading to a weak bureaucratic structure unable to implement the new policy means like planning which should protect public goods in the forest and counter the effects of the market driven uses of the forest. 


\subsection{Transnational regimes and state bureaucracies}

Forest certification started as a transnational regime, with the conservation-oriented private sector as the main driver. By means of the national implementation of the schemes, with the active presence of national conservation-oriented actors and little participation from national bureaucracies, these transnational regimes became influential at the national level. Burns et al. (2016) observed this in the case of FSC in Argentina, where a national environmental NGO housed FSC and acted as coordinator of the development of the standards. However, despite what is often claimed (Cashore 2002, Pattberg 2005, Auld et al. 2008), state bureaucracies play a decisive and active role in forest certification processes. In Argentina, Burns et al. (2016) found that forest certification through FSC was first put into the political agenda by the Secretariat of Agriculture through organizing a workshop about the potential implementation of FSC in the country. During the development of FSC national standards, both, the Secretariat of Environment and Sustainable Development and Secretariat of Agriculture, Livestock, and Fisheries participated as members of the environmental chamber. This shows that national forest bureaucracies supported FSC in Argentina, at least in the beginning, through both informational instruments and the provision of staff. By involvement in the negotiation of standards, national bureaucracies could try to influence the final standards according to their interests. However, national standards for FSC were never achieved, showing the great competition faced by this system (Espach 2006, Burns et al. 2016, Giessen et al. 2016).

As a response to the development of a conservation-oriented forest certification scheme of high standards like FSC, production-oriented private sectors created more industry-friendly systems that could compete with, and later even replace conservation-oriented systems. By forming coalitions with national state production-oriented bureaucracies, these competing schemes gained strength. In Argentina, Burns et al. (2016) found that the formulation of national standards for PEFC endorsement, an initiative carried out by the forestry associations in coalition with the Ministry of Agriculture and the National Standardization bureaucracy, presented strong competition to FSC. In this case, the Ministry of Agriculture, by becoming allies with the forestry associations through the provision of informational instruments and technical expertise in standard development, and later by incentive instruments, such as paying for the PEFC endorsement procedure, supported the creation of a more industry-friendly scheme that could compete with, and preferably even replace FSC in the country. A similar situation was observed in Indonesia, where the Ministry of Forestry supported forest certification by funding a national initiative (LEI) competing with FSC (Bartley 2010, Wibowo et al. unpublished). One can argue that private landowners have more power in countries like Argentina and Indonesia with weak state capacities, however the same pattern was observed in countries with strong state capacity like Finland and Germany. In Finland, PEFC, with the support of forest owner organizations, out-competed FSC, with $95 \%$ of the forests in the country certified under PEFC only one year after the approval of the standard (Kestikalo et al. 2009). In Germany, PEFC was created by the forest sector in coalition with other landowners and managers across Europe as a response to the ENGO driven FSC. In this case PEFC had a strong support from almost all private and state landowners (Cashore et al. 2003). As suggested by Öberg et al. (2011) corporatism does not depend on whether institutions are weak or strong but rather whether they are willing or not to engage in mutual exchanges.

These results support our hypothesis that other than often claim state bureaucracies play an important role in the implementation of transnational regimes at the national level. In line with these results fur- 
ther studies even suggest that state bureaucracies are now reclaiming their role in private governance by means of legality certification processes as well as other mandatory certification mechanisms (Sahide et. al. 2015, Burt et al. 2016, Giessen et al. 2016).

In forest certification processes international actors seek coalitions with different state bureaucracies. Burns et al. (2016) found that in Argentina both the European Union and the World Bank supported different bureaucracies in the formulation of national standards for PEFC endorsement, an initiative carried out by the forestry associations in coalition with the Ministry of Agriculture that emerged as strong competition for FSC, almost replaced it. By seeking coalitions with international actors, the Ministry of Agriculture (formerly the Secretariat) in coalition with the EU and the National Standardization bureaucracy in coalition with the World Bank, tried to enhance their power in the competition for policy domain on standard development of forest certification schemes. However, the forestry associations supported the National Standardization bureaucracy, which would not be permanently in charge, giving administrative power back to the landowners' sector. In the competition between these two bureaucracies, the Ministry of Agriculture could not achieve the policy domain of writing the national standards, and support from the EU was dropped. As concluded by Burns et al. (2016), in situations where new promising venues for political influence open, private actors prefer ad hoc coalitions with weaker bureaucracies that would not be permanent and with less technical knowledge.

\subsection{Federalism and International and Transnational forest regimes}

The political system of federal countries like Argentina provides multiple institutional access points for policy change that international and transnational regimes try to use in order to influence the domestic level, consequently changing the power balance of the domestic networks (Burns et al. 2016). Domestic actors then can use these regimes to shift the power balance in their favor. However, how important federalism is depends on how responsibilities regarding certain issues are vertically distributed between the national and the subnational governments (Lopreite 2014). In cases where the issue at stake is within provincial competencies, the national level will try to use the international sphere to increase their responsibility (Scharpf 2006, Wibowo and Giessen 2015). This is the case with forests in Argentina, whose responsibility toils within the provincial level (Burns and Giessen 2014, Burns and Giessen 2016, Burns et al. 2016). By making coalitions with the World Bank, national forest bureaucracies were able to approve a new national forest law providing for "minimum standards" regulation, meaning that every province must reorganize its provincial laws in order to meet minimum requirements (Burns and Giessen 2016). By the approval of this law, the Directorate for Native Forests increased their power in relation to the provincial level. As pointed out by Hofmann (2002), national bureaucracies benefit by gaining influence through the implementation of the International Forest Regime Complex (Hofmann 2002).

In the case of developing forest certification schemes in Argentina, Burns et al. (2016) found that national bureaucracies, like the Ministry of Agriculture, tried to increase their power over the provinces by leading the national initiative of an industry-friendly scheme like PEFC with the support of private landowners. In this case, despite the provinces retaining the power over forest issues, national bureaucracies by means of transnational regimes increased their power. The provincial bureaucracies, on the other hand, try to retain their power in forest issues but at the same time support their stable coalitions with private actors in their territories. In the case of forest certification in Argentina this was seen both in the 
development of FSC and PEFC. In the case of FSC, they tried to obstruct the development of regional standards, especially in the regions were forest landowners are stronger, like the Mesopotamia region. At the same time they joined the development of the PEFC standard, being part of the CERFOAR association (Burns et al. 2016). In cases where the jurisdiction over an issue lies at the national level, the subnational level can still use agenda setting and bills initiation to influence policy change (Lopreite 2014). 


\section{Strategic options for stake holders}

Based on the results from this dissertation the following strategic options are suggested to the main national forest relevant state bureaucracies in Argentina. These suggestions could also be applied to national state bureaucracies in other federal countries.

The main problem national state bureaucracies dealing with forests in Argentina face is that, except for national parks, which are under the jurisdiction of the national government, forests toile within the political responsibility of the provinces and are subject to provincial laws under the umbrella of national laws (Article 124 of the National Constitution 1994). This makes the subnational bureaucracies involved in the forest sector important actors competing with national state bureaucracies as well as potential coalition partners. Moreover, forests are mainly owned privately: $99.7 \%$ of plantation forests and $93.5 \%$ of natural forests are privately owned (Burns and Giessen 2014) making the private forest landowners another important actor in forest related issues.

\subsection{Directorate for Forestry Production, Ministry of Agriculture}

In facing the above mentioned problem, the Directorate for Forestry Production responsible for forest plantations, timber processing industries and agroforestry, within the Ministry of Agriculture can build coalitions with international and transnational organizations in order to change the power balance towards national level.

The World Bank, as an international organization promoting private sector investment in forests as well as new environmental markets and voluntary private sector regulation by means of neoliberal elements (Humphreys 2006) is an excellent coalition partner for the Ministry of Agriculture and specifically for the Directorate for Forestry Production, supporting their stable coalitions with private forest landowners. A coalition with the World Bank will not only increase their power by means of funding but also by a high level of political support and credibility to foreign investors. An increase in investments in plantation forests and related industries would lead to an increase in the representation of the forest sector in the national GDP and hence an increase in power of the Directorate for Forestry Production vis-à-vis other national state actors.

National state bureaucracies can also use international issues to strengthen their positions vis-à-vis competing agencies, both at the national as well as the provincial level, by taking up issues, discourses and norms to legitimize their roles as well as by finding domestic or international coalition partners (Bernstein and Cashore,2012; Giessen 2013, Wibowo and Giessen 2015). As an example the Directorate for Forestry Production can use the emerging bioeconomy discourse (Pülzl et al. 2014, Kleinschmit et al. 2014) as well as recent commitments of reduction of emissions made by the country in the climate change convention (UNFCCC) to promote bioenergy with wood biomass from plantation forests as a source of renewable energy and hence increase their responsibilities in policy domain.

The climate change convention (UNFCCC) and the Convention to Combat Desertification (UNCCD) are examples of international agreements the Directorate for Forestry Production can use to increase their power. Even though the Directorate for Forestry Production is not the application authority of these agreements they can benefit from them, for example, by promoting plantation forests as important car- 
bon sinks and developing clean development mechanism (CDM) projects with plantation forests in areas where normally plantation forests are not established. As well they can promote plantation forests as means of rehabilitation of degraded lands and fighting desertification.

\subsection{Directorate for Native Forests, Secretariat of Environment and Sustainable Development}

As well as the Directorate for Forestry Production, the Directorate for Native Forests can build coalitions with international and transnational organizations in order to change the power balance towards national level.

The World Bank and the Global Environment Facility (GEF) can also be important coalition partners for the Directorate for Native Forests through funding of forest biodiversity conservation projects and poor communities living in the forests, in line with the World Bank's forest strategies. This coalition with such strong actors will increase the power of the Directorate for Native Forests. Such was the case with previous projects with funding from the World Bank and GEF that led to a new national forest law which grants this bureaucracy permanent funding from the national budget, allowing it to double its staff after two years of implementation.

Most international forest agreements are focused on native forests, competence of the Directorate for Native Forests. By using these agreements this bureaucracy can increase its policy domain and hence its power. Such is the case of the climate change convention and especially REDD+. By developing a REDD+ national strategy with potential international funding this bureaucracy can increase its power vis-à-vis other state and non-state actors competing for forest land.

Transnational regimes can also be uses by national state bureaucracies to increase their power. Such is the case of forest certification. While in Argentina so far FSC, a conservation-oriented system, has been almost replaced by PEFC, a more industry-friendly scheme developed with the support of the forestry associations in coalition with the Ministry of Agriculture and the National Standardization bureaucracy a coalition between the Directorate for Native Forests and international and domestic environmental NGOs could increase the influence of FSC in the country. Taking an active role in the development of national standards for FSC could provide the Directorate for Native Forests some influence in the management of plantation forests, increasing their policy domain.

New legality verification mechanisms, so far absent in Argentina could also increase the power of this bureaucracy. By forming coalition with international actors as for example the EU through FLEGT the Directorate for Native Forests could take a leading role in the development of a national legality verification system. 


\section{References}

Agrawal, A., A. Chhatre, R. Hardin. 2008. Changing governance of the world's forests. Science 320: 14601462.

Arts, B. 2014. Assessing forest governance from a 'Triple G' perspective: Government, governance, governmentality. Forest Policy and Economics 49: 17-22.

Arts, B., I. Babili. 2012. Global Forest Governance: Multiple Practices of Policy Performance. In Forest and Nature Governance, eds. B. Arts, J. Behagel, S. van Bommel, J. Koning and E. Turnhout, pp. 111-132. Springer, Netherlands.

Arts, B., M. Buizer. 2009. Forests, discourses, institutions. Forest Policy and Economics 11: 340-347.

Arts, B., J. Behagel, S. van Bommel, J. de Koning, E. Turnhout. 2013. Forest and Nature Governance: A Practice Based Approach (World Forests 14). Springer, Dordrecht.

Auld, G., L. H. Gulbrandsen, C. L. McDermott. 2008. Certification schemes and the impacts on forest and forestry. Annual Review of Environment and Resources 33: 187-211.

Bartley, T. 2010. Transnational private regulation in practice: The limits of forest and labor standards certification in Indonesia. Business and Politics 12(3): Art. 7.

Bartley, T. 2014. Transnational governance and the re-centered state: Sustainability or legality? Regulation \& Governance 8: 93-109.

Bauer, S., S. Andresen, F. Biermann. 2012. International bureaucracies. In: Global Environmental Governance Reconsidered, 27-44.

Bell, S., A. Hindmoor. 2012. Governance without government? The case of the forest stewardship council. Public Administration 90(1): 144-159.

Bennett, A., C. Elman. 2006. Qualitative Research: Recent Developments in Case Study Methods. Annu. Rev. Polit. Sci. 9:455-76

Bernstein, S., B. Cashore. 2000. Globalization, Four Paths of Internationalization and Domestic Policy Change: The Case of EcoForestry in British Columbia, Canada. Canadian Journal of Political Science 33: 67-99

Bernstein, S., B. Cashore. 2012. Complex global governance and domestic policies: four pathways of influence. International Affairs 88: 585-604

Biermann, F., B. Siebenhüner, S. Bauer, P. Busch, S. Campe, K. Dingwerth, T. Grothmann, R. Marschinski, M. Taradell. 2009. Studying the influence of international bureaucracies. A conceptual framework. In Managers of global change: the influence of international environmental bureaucracies, eds. F. Biermann, and B. Siebenhüner, pp. 37-74. Cambridge, MA: MIT Press. 
Brockhaus, M., K. Obidzinski, A. Dermawan, Y. Laumonier, C. Luttrell. 2012. An overview of forest and land allocation policies in Indonesia: is the current framework sufficient to meet the needs of REDD+? Forest Policy and Economics 18: 30-37.

Brockhaus, M., M. Di Gregorio, S. I. Mardiah. 2014. Governing the design of national REDD +: An analysis of the power of agency. Forest Policy and Economics 49: 23-33

Brukas, V. and C. N. Hjorts $\varnothing$. 2004. A Power Analysis of International Assistance to Lithuanian Forestry, Scandinavian Journal of Forest Research 19: 166-176

Burns, S. L. and L. Giessen. 2014. Identifying the main actors and their positions on international forest policy issues in Argentina. Bosque 32(2): 163-173. http://dx.doi.org/10.4067/S0717-92002014000200004

Burns, S. L. and L. Giessen. 2016. Dismantling Comprehensive Forest Bureaucracies: Direct Access, the World Bank, Agricultural Interests, and Neoliberal Administrative Reform of Forest Policy in Argentina. Society and Natural Resource 29(4): 493-508. http://dx.doi.org/10.1080/08941920.2015.1089608

Burns, S. L., Yapura, P. F. and L. Giessen. 2016. State actors and international forest certification policy: Coalitions behind FSC and PEFC in federal Argentina. Land Use Policy 52: 23-29. http://dx.doi.org/10.1016/j.landusepol.2015.12.005

Burns, S. L., Krott, M., Sayadyan, H. and L. Giessen. Unpublished. The World Bank's power on environmental and natural resources policies in Armenia: neoliberal changes and post-soviet heritage.

Burt B., Burns S.L., Sahide A., Wibowo A., Giessen L. 2016. Governments reclaiming role in forest certification. IUFRO Spotlight \#39 / July 2016. IUFRO, Vienna, online under http://www.iufro.org/media/iufrospotlights/

Cashore, B. 2002. Legitimacy and the Privatization of Environmental Governance: How Non State Market-Driven (NSMD) Governance Systems Gain Rule Making Authority. Governance: An International Journal of Policy and Administration 15(4): 503-529.

Cashore, B., Stone, M.W. 2012. Can legality verification rescue global forest governance? Analyzing the potential of public and private policy intersection to ameliorate forest challenges in Southeast Asia. Forest policy and economics 18: 13-22.

Cashore, B., Auld, G., Newsom, D. 2003. Forest certification (eco-labeling) programs and their policymaking authority: explaining divergence among North American and European case studies. Forest Policy and Economics 5: 225-247.

Cashore, B., Auld, G., Newsom, D. 2004. Governing through Markets: Forest Certification and the Emergence of Non-state Authority. Yale University Press, New Haven.

Cashore, B., G. C. Van Kooten, I. Vertinsky, G. Auld, J. Affolderbach. 2005. Private or self-regulation? A comparative study of forest certification choices in Canada, the United States and Germany. Forest Policy and Economics 7: 53-69. 
Collier, D. 2011. Understanding Process Tracing. APSC 44: 823-830.

Davies, P. H. J. 2001. Spies as informants: triangulation and the interpretation of Elite interview data in the study of the intelligence and security services. Politics 21: 73-80.

Davies, M., R. Woodward. 2014. International Organizations. A Companion. Edward Elgar Publishing Limted, Cheltenham, UK. ISBN 9781783474165

Devkota, R. R., 2010. Interests and Power as Drivers Of Community Forestry: A CaseStudy of Nepal. Universitätsverlag Göttingen.

Dimitrov, R. S. 2005. Hostage to norms: states, institutions and global forest politics. Global Environmental Politics 5: 1-24.

Dimitrov, R. S., D. F. Sprinz, G. M. DiGiusto, A. Kelle. 2007. International Nonregimes: A Research Agenda. International Studies Review 9: 230-258.

Dingwerth, K. 2005. Private Environmental Governance and the South. Paper presented at the Conference "International Organisations and Global Environmental Governance". Potsdam, Germany, 2 -3 December 2005

Dingwerth, K, P. Pattberg. 2009. World Politics and Organizational Fields: The Case of Sustainability Governance. European Journal of International Relations 15: 707-743

Edwards, P., D. Kleinschmit. 2013. Towards a European forest policy - Conflicting courses. Forest Policy and Economics 33: 87-93.

Ellefson, P.V., C.M. Hibbard, M. A. Kilgore. 2006. Managing across levels of government: Evaluation of federal-state roles and responsibilities involving nonfederal forests in the United States. Forest Policy and Economics 8: 652-666

Elmqvist, M., and L. Rylander. 2010. Outcome Review of SIDA'S Development Cooperation with Armenia 1999-2009. Final Report. SIDA Review 2010:21.

Espach, R. 2005. Private regulation amid public disarray: An analysis of two private environmental regulatory programs in Argentina. Business and Politics 7(2): Art. 3

Espach, R. 2006. When is Sustainable Forestry Sustainable? The Forest Stewardship Council in Argentina and Brazil. Global Environmental Politics 6: 55-84

Fabra-Crespo, M., E. Rojas-Briales. 2015. Analysis of mass media news on forest issues: a case study of Spain. Forest Systems 24: e029.

Fischer, R., Y. Hargita, S. Günter. 2016. Insights from the ground level? A content analysis review of multinational REDD+ studies since 2010. Forest Policy and Economics 66: 47-58.

Fletcher, R. 2010. Neoliberal Environmentality: Towards a Poststructuralist Political Ecology of the Conservation Debate. Conservation and Society 8: 171-181 
Frantzi, S., N. T. Carter, J. C. Lovett. 2009. Exploring discourses on international environmental regime effectiveness with $Q$ methodology: a case study of the Mediterranean Action Plan. Journal of Environmental Management 90: 177-186.

Gale, F., M. Haward. 2011. Global Commodity Governance: State Responses to Sustainable Forest and Fisheries Certification. Basingstoke: Palgrave Macmillan.

Gale, F., T. Cadman. 2014. Whose Norms Prevail? Policy Networks, International Organizations and "Sustainable Forest Management". Society and Natural Resources 27: 170-184

Gartland, H. M. 2012. Política y legislación forestales [Forest policy and legislation]. Hemisferio Sur, Buenos Aires, Argentina

Gautier, D., T. A. Benjaminsen, L. Gazull, and M. Antona. 2013. Neoliberal Forest Reform in Mali: Adverse Effects of a World Bank "Success". Society and Natural Resources 26:702-716.

George, A.L., A. Bennett. 2005. Case Studies and Theory Development in the Social Sciences. Cambridge, MA and London, England: MIT Press.

Giessen, L. 2013. Reviewing the main characteristics of the international forest regime complex and partial explanations for its fragmentation. International Forestry Review 15: 60-70.

Giessen, L., G. Buttoud. 2014. Defining and assessing forest governance. Forest Policy and Economics 49: 1-3.

Giessen, L., M. Krott, T. Möllmann. 2014. Increasing representation of states by utilitarian as compared to environmental bureaucracies in international forest and forest-environmental policy negotiations. Forest Policy and Economics 38: 97-104.

Giessen, L., Burns, S. L., Sahide, A. M. K., Wibowo, A. 2016. From governance to government: The key role of state bureaucracies in forest and agricultural certification. Policy and Society 35: 71-89. http://dx.doi.org/10.1016/i.polsoc.2016.02.001

Glück, P., A. Angelsen, M. Appelstrand, S. Assembe-Mvondo, G. Auld, K. Hogl. 2010. Core components of the international forest regime complex (Vol. 28, pp. 37-55). IUFRO.

Gulbrandsen, L. 2003. The evolving forest regime and domestic actors: strategic or normative adaptation? Environmental Politics 12: 95-114.

Gulbrandsen, L. H. 2010. Transnational Environmental Governance: The Emergence and Effects of the Certification of Forests and Fisheries. Cheltenham, UK/Northampton (MA), USA, Edward Elgar. 213 p.

Gulbrandsen, L. H. 2014. Dynamic governance interactions: Evolutionary effects of state responses to non-state certification programs. Regulation \& Governance 8: 74-92.

Helm, C., D. F. Sprinz. 2000. Measuring the Effectiveness of International Environmental Regimes. Journal of Conflict Resolution 44: 630-652. 
Hisschemöller, M., J. Gupta. 1999. Problem-solving through International Environmental Agreements: The Issue of Regime Effectiveness. International Political Science Review 20: 151-174.

Ho, P. 2006. Credibility of Institutions: Forestry, Social Conflict and Titling in China. Land Use Policy 23: 588-603.

Hofmann, F. 2002. Globale Waldpolitik in Deutschland - Eine Untersuchung über die Wirkung internationaler Regime in föderalen Strukturen. Albert-Ludwigs-Universität Freiburg.

Hogl, K., R. Nordbeck, E. Kvarda. 2009. When international impulses hit home: The role of domestic policy subsystem configurations in explaining different types of sustainability strategies. Forest Policy and Economics 11: 357-364.

Hovi, J., D. F. Sprinz, A. Underdal. 2003. The Oslo-Potsdam solution to measuring regime effectiveness: Critique, response, and the road ahead. Global Environmental Politics 3: 74-96.

Howlett, M., M. Ramesh. 1995. Studying Public Policy: Policy Cycles and Policy Subsystems. 2nd edition. Toronto, Canada. Oxford University Press. $239 \mathrm{p}$

Howlett, M. J. Rayner. 2010. Overcoming the challenges to integration: embracing complexity in forest policy design through multi-level governance. In: Rayner, J., Buck, A. \& Katila, P.: Embracing Complexity: Meeting the challenges of international forest governance. A global assessment report. Prepared by the Global Forest Panel on the International Forest Regime. IUFRO World Series Volume 28. Vienna. 172p

Hsieh, H. F., S. E. Shannon. 2005. Three approaches to qualitative content analysis. Qualitative health research 15: 1277-1288.

Hudson, B. 2012. Federal Constitutions, Global Governance, and the Role of Forests in Regulating Climate Change. Indiana Law Journal 87: 1455-1515

Hudson, B., E. Weinthal. 2009. Seeing the Global Forest for the Trees: How U.S. Federalism Can Coexist With Global Goverance of Forests. Journal of Natural Resources Policy Research 1: 353-365.

Humphreys, D. 1999. The evolving forests regime. Global Environmental Change 9: 251-254.

Humphreys, D. 2006. Logjam - Deforestation and the crisis of global governance. Earthscan, London.

Humphreys, D. 2009. Discourse as ideology: Neoliberalism and the limits of international forest policy. Forest Policy and Economics 11: 319-325.

Hysing, E. 2009. Governing with government? The private governance of forest certification in Sweden. Public Administration 87: 312-326.

Keskitalo, E. C. H., C. Sandström, M. Tysiachniouk, J. Johansson. 2009. Local consequences of applying international norms: differences in the application of forest certification in northern Sweden, northern Finland, and northwest Russia. Ecology and Society 14: 1. 
Kleinschmit, D., B. Lindstad, B. J. Thorsen, A. Toppinen, S. Baardsen, A. Roos, 2014. Shades of green: a social scientific view on bioeconomy in the forest sector. Scandinavian Journal of Forest Research 29: 402-410

Klinke, A. 2009. Deliberative transnationalism - Transnational governance, public participation and expert deliberation. Forest Policy and Economics 11: 348-356.

Koontz, T. M., J. Newig. 2014. From Planning to Implementation: Top-Down and Bottom-Up Approaches for Collaborative Watershed Management. Policy Studies Journal 42: 416-442.

Krasner, S. D. 1982. Structural Causes and Regime Consequences: Regimes as Intervening Variables. International Organization 36:185-205.

Krott, M. 2005. Forest policy analysis. Dordrecht, Netherlands: Springer.

Krott, M., A. Bader, C. Schusser, R. R. Devkota, A. Maryudi, L. Giessen, H. Aurenhammer. 2014. Actorcentred power: The driving force in decentralised community based forest governance. Forest Policy and Economics 49: 34-42.

Larson, A. M. 2003. Decentralisation and forest management in Latin America: Towards a working model. Public Administration and Development 23: 211-226.

Leguizamón, A. 2013. Modifying Argentina: GM soy and socio-environmental change. Geoforum 53: 149160.

Levine, A. 2002. Convergence or convenience? International conservation NGOs and development assistance in Tanzania. World Development 30: 1043-1055.

Levitsky, S., M. V. Murillo. 2008. Argentina: From Kirchner to Kirchner. Journal of Democracy 19: 16-30.

Lindstad, B. H. 2015. Changes in Norwegian forest policies: what are the effects of the international forest regime complex? Scandinavian Journal of Forest Research 30: 246-254.

Lindstad, B. H., B. Solberg. 2010. Challenges in determining national effects of international policy processes: Forest protection in Norway as a case. Forest Policy and Economics 12: 489-496.

Lopreite, D. 2014. Explaining policy outcomes in federal contexts: the politics of reproductive rights in Argentina and Mexico. Bulletin of Latin American Research 33: 389-404.

Lorenzoni, I., D. Benson. 2014. Radical institutional change in environmental governance: Explaining the origins of the UK Climate Change Act 2008 through discursive and streams perspectives. Global Environmental Change 29: 10-21.

Marschinski, R., S. Behrle 2009. The World Bank: Making the business case for the environment. In Managers of global change: the influence of international environmental bureaucracies, eds. F. Biermann, and B. Siebenhüner, pp. 101-142. Cambridge, MA: MIT Press. 
Maryudi, A., R. R. Devkota, C. Schusser, C. M. Yufanyi, M. Salla, H. Aurenhammer, R. Rotchanaphatharawit, M. Krott. 2012. Back to Basics: Considerations in Evaluating the Outcomes of Community Forestry. Forest Policy and Economics 14: 1-5

McDermott, C. L., B. Cashore, P. Kanowski. 2010. Global Environmental Forest Policies: An International Comparison. London, UK. Earthscan.

Mohammed, A. J., M. Inoue. 2014. Linking outputs and outcomes from devolved forest governance using a Modified Actor-Power-Accountability Framework (MAPAF): Case study from Chilimo forest, Ethiopia. Forest Policy and Economics 39: 21-31

Nathan, I., T. E. Boon. 2012. Constraints and Options in Local Forest Management in Cambodia: Is Decentralization a Solution? Journal of Sustainable Forestry 31: 396-420.

Neuman, W. L. 2005. Social research methods. Quantitative and qualitative approaches. London, Uk Allyn and Bacon.

Öberg, P., T. Svensson, P. M. Christiansen, A. S. Nørgaard, H. Rommetvedt, G. Thesen. 2011. Disrupted Exchange and Declining Corporatism: Government Authority and Interest Group Capability in Scandinavia. Government and Opposition 46: 365-391.

Otto, I. M., V. Chobotová 2013. Opportunities and constraints of adopting market governance in protected areas in Central and Eastern Europe. International Journal of the Commons 7: 34-57

Pattberg, P. 2005. The Institutionalization of Private Governance: How Business and Nonprofit Organizations Agree on Transnational Rules. Governance 18: 589-610.

Pattberg, P. 2007. Private Institutions and Global Governance. The New Politics of Environmental Sustainability. Cheltenham, UK and Northampton, USA: Edward Elgar. 320 pp.

Pattberg, P. 2012. Transnational Environmental Regimes. In: F. Biermann and P. Pattberg (eds.): Global Environmental Governance Reconsidered. MIT Press, Cambridge, MA. ISBN: 9780262017664 . 318 pp.

Palmer, C., S. Engel. 2007. For Better or for Worse? Local Impacts of the Decentralization of Indonesia's Forest Sector. World Development 35: 2131-2149

Pengue, W. A. 2005. Transgenic Crops in Argentina: The Ecological and Social Debt. Bulletin of Science, Technology and Society 25: 314-322.

Peters, B. G. 2010. The Politics of Bureaucracy- An Introduction to Comparative Public Administration. Routledge, Oxon

Pülzl, H., D. Kleinschmi, B. Arts. 2014. Bioeconomy - an emerging meta-discourse affecting forest discourses? Scandinavian Journal of Forest Research 29: 386-393

Rahman, M. S., L. Giessen. 2014. Mapping international forest-related issues and main actors' positions in Bangladesh. International Forestry Review 16: 586-601. 
Rayner, J., M. Howlett, J. Wilson, B. Cashore, G. Hoberg. 2001. Privileging the sub-sector: critical subsectors and sectoral relationships in forest policy-making. Forest Policy and Economics 2: 319-332.

Rayner, J., D. Humphreys, Frederic Perron Welch, Ravi Prabhu, P. Verkooijen. 2010. Introduction. In: Rayner, J., Buck, A.\& Katila, P. (Eds). Embracing Complexity: Meeting the challenges of international forest governance. IUFRO World Series Volume 28. Vienna. 9-18.

Romero, J. E. 2012. Forest conservation in Argentina: early analysis of the forest law implementation in the Chaco ecoregion. Master of Science Thesis. UBC, Vancouver, Canada.

Roth, R. J., W. Dressler. 2012. Market-oriented conservation governance: The particularities of place. Geoforum 43:363-366

Sadath, N., D. Kleinschmit, L. Giessen. 2013. Framing the tiger - A biodiversity concern in national and international media reporting. Forest Policy and Economics 36: 37-41.

Sahide, M. A. K., S. Burns, A. Wibowo, L. Giessen. 2015. The changing governance of agrarian certification- from voluntary private governance to mandatory state labelling in Indonesia's palm oil sector. Jurnal Manajemen Hutan Tropika 21: 169-178. http://journal.ipb.ac.id/index.php/jmht/article/view/10798

Sahide, M. A. K., S. Supratman, A. Maryudi, Y. S. Kim, L. Giessen. 2016. Decentralisation policy as recentralisation strategy: forest management units and community forestry in Indonesia. International Forestry Review 18: 78-95.

Sayadyan, H., R. Moreno-Sanchez. 2006. Forest policies, management and conservation in Soviet (19201991) and post-Soviet (1991-2005) Armenia. Environmental Conservation 33: 1-13

Scharpf, F. W. 2006. The Joint-Decision Trap Revisited. JCMS 44: 845-864.

Schusser, C. 2013. Who determines biodiversity? An analysis of actors' power and interests in community forestry in Namibia. Forest Policy and Economics 36: 42-51

Schusser, C., M. Krott, M. C. Yufanyi Movuh, J. Logmani, R. R. Devkota, A. Maryudi, M. Salla, N. D. Bach. 2015. Powerful stakeholders as drivers of community forestry - Results of an international study. Forest Policy and Economics 58: 92-101

Singer, B. 2009. Putting the National Back in Forest-Related Policies. The International Forests Regime and the Evolution of Policies in Brazil, Cameroon and Indonesia. PhD in Political Science. Institut d'Etudes Politiques de Paris, France.

Singh, S. 2009. World Bank-directed Development? Negotiating Participation in the Nam Theun 2 Hydropower Project in Laos. Development and Change 40:487-507

Smouts, M. C. 2008. The issue of an International Forest Regime. International Forestry Review 10: 429432 
Sprinz, D. F. 2005. Regime Effectiveness: The Next Wave of Research. Berlin Conference on the Human Dimensions of Global Environmental Change. Potsdam, 2-3 December.

Sprinz, D. F., and C. Helm. 1999. The Effect of Global Environmental Regimes: A Measurement Concept. International Political Science Review 20: 359-369.

Tuozzo, M. F. 2004. World Bank, governance reforms and democracy in Argentina. Bulletin of Latin American Research 23: 100-118.

Tuozzo, M. F. 2009. World Bank influence and institutional reform in Argentina. Development and Change 40: 467-485.

Underdal, A. 1992. The Concept of Regime "Effectiveness". Cooperation and Conflict 27: 227-240.

Wehkamp, J., A. Aquino, S. Fuss, E. W. Reed. 2015. Analyzing the perception of deforestation drivers by African policy makers in light of possible REDD+ policy responses. Forest Policy and Economics 59: 7-18.

Wibowo, A. 2015. International Forest Policies in Indonesia: International Influences, Power Changes and Domestic Responses in REDD+, One Map and Forest Certification Politics. PhD Faculty of Forest Sciences and Forest Ecology. Georg-August-Universität Göttingen. 1. Aufl. - Göttingen: Cuvillier.

Wibowo, A., L. Giessen. 2015. Power Dynamics of the State Agencies in Forest Land Use Politics: Insights from the REDD+ Programme and the One Map Policy in Indonesia. Land Use Policy 49: 131-141.

Wibowo, A., M. A. K. Sahide, L. Giessen. Unpublished. Reclaiming legitimacy from voluntary private to mandatory state forest certification: Case of Indonesia.

Young, O. R. 2001. Inferences and Indices. Evaluating the Effectiveness of International Environmental Regimes. Global Environmental Politics 1: 99-121.

Young, O. R. 2003. Determining regime effectiveness: a commentary on the Oslo-Potsdam solution. Global Environmental Politics 3: 97-104.

Young, O. R. 2004. Institutions and the growth of knowledge: Evidence from international environmental regimes. International Environmental Agreements: Politics, Law and Economics 4: 215-228.

Yufani Movuh, M. C., C. Schusser. 2012. Power, the Hidden Factor in Development Cooperation. An Example of Community Forestry in Cameroon. Open Journal of Forestry 2: 240-251 


\section{Annex}

Burns, S. L. and L. Giessen. 2014. Identifying the main actors and their positions on international forest policy issues in Argentina. Bosque 32(2): 163-173. http://dx.doi.org/10.4067/S0717-92002014000200004

Burns, S. L. and L. Giessen. 2016. Dismantling Comprehensive Forest Bureaucracies: Direct Access, the World Bank, Agricultural Interests, and Neoliberal Administrative Reform of Forest Policy in Argentina. Society and Natural Resource 29(4): 493-508. http://dx.doi.org/10.1080/08941920.2015.1089608

Burns, S. L., Yapura, P. F. and L. Giessen. 2016. State actors and international forest certification policy: Coalitions behind FSC and PEFC in federal Argentina. Land Use Policy 52: 23-29. http://dx.doi.org/10.1016/j.landusepol.2015.12.005

Burns, S. L., Krott, M., Sayadyan, H. and L. Giessen. The World Bank's power on environmental and natural resources policies in Armenia: neoliberal changes and post-soviet heritage. Under review in World Development. 


\title{
Identifying the main actors and their positions on international forest policy issues in Argentina
}

\author{
Identificación de los principales actores y sus posiciones sobre asuntos internacionales \\ de política forestal en Argentina \\ Sarah L Burns ${ }^{\mathrm{a}, \mathrm{b} *}$, Lukas Giessen ${ }^{\mathrm{a}}$

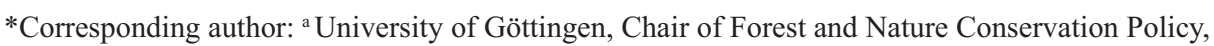 \\ Germany, sarah.burns@forst.uni-goettingen.de \\ ${ }^{\text {b }}$ Universidad Nacional de La Plata, Facultad de Ciencias Agrarias y Forestales, Laboratorio de Investigación de Sistemas \\ Ecológicos y Ambientales, La Plata, Argentina.
}

\begin{abstract}
SUMMARY
Since the Earth Summit in Rio in 1992, forest management and conservation have become important issues in international forestrelated politics and policies. As a result, different international initiatives have dealt with the subject directly or indirectly, building up a fragmented international forest regime complex made of international laws and agreements about forests. The diverse elements of this regime complex are differently made relevant by various actors in different countries. The aim of this study was to identify the most relevant forest issue elements in Argentina as well as the main involved actors and their positions towards these elements as a result of their interests. To identify the issues, content analysis of documents was employed on public sources (newspapers, websites) as well as expert sources (personal interviews and professional journals) from 2008 - 2012. The most relevant actors were identified and categorized. The positions of the different actors were obtained analyzing the different sources. The forest issue elements found to be relevant in Argentina are: climate change and forests, forest biodiversity, regional forest-related policy initiatives, competing forest certification schemes, desertification, bilateral forest related disputes and forest-related support by international organizations. The various actors identified showed different positions regarding a diversity of issues, being climate change and forests the most conflictive concern among actors, especially among environmental NGOs and forestry associations and the Secretariat of Environment and Sustainable Development and the Ministry of Agriculture, Livestock and Fisheries.
\end{abstract}

Key words: forest policy, international forest regime complex, relevance, implementation.

\section{RESUMEN}

Desde la Cumbre de la Tierra, en 1992, el manejo y conservación de los bosques se han convertido en temas importantes en la política forestal internacional. Como resultado, distintas iniciativas internacionales abordaron el tema de manera directa o indirecta, conformándose un cuerpo normativo de leyes y acuerdos fragmentado sobre los bosques de alcance internacional. Los temas que conforman este régimen normativo se convierten en relevantes de distinta manera por medio de varios actores en diferentes países. El objetivo del presente trabajo fue identificar los principales temas de política forestal internacional relevantes en Argentina así como los principales actores involucrados y sus posiciones frente a los mismos como resultado de sus intereses. Para la identificación de estos temas se consultaron fuentes públicas (diarios nacionales, páginas web) así como expertas (entrevistas y publicaciones profesionales) entre el 2008 - 2012. Los actores más importantes fueron identificados y categorizados. Las posiciones de los distintos actores se obtuvieron mediante el análisis de las fuentes. Los temas de política forestal internacional identificados en la Argentina fueron: cambio climático y bosques, biodiversidad en sistemas forestales, iniciativas de políticas forestales regionales, competencia de sistemas de certificación forestal, desertificación, disputas bilaterales referentes a bosques y financiamiento de organismos internacionales en temas forestales. Los diferentes actores identificados presentaron posiciones encontradas con respecto a los temas, detectándose el cambio climático y bosques como el más conflictivo entre actores, principalmente entre ONG ambientalistas y asociaciones forestales y la Secretaría de Ambiente y Desarrollo Sustantable y el Ministerio de Agricultura, Ganadería y Pesca.

Palabras clave: política forestal, complejo de régimen forestal internacional, relevancia, implementación.

\section{INTRODUCTION}

After the Rio Summit in 1992, a growing number of international policies and regimes addressing forests have evolved into what can be described as an international fo- rest regime complex (IFR-C) (Humphreys 2006, Rayner et al. 2010, Giessen 2013). This regime complex attempts to influence domestic policies at national levels. How this influence occurs, however, is assumed to be different in each country. In order to become influential, a political is- 
sue needs to be put on the agenda (Howlett and Ramesh 1995). Conflicting interests about the substance, then, make the issue visible empirically as a political conflict. In the politics surrounding the issue, a number of actors concerned will then take positions based on their interests (Krott 2005, Wibowo and Giessen 2012).

The formulation of the IFR-C has already been analyzed to a large degree (Humphreys 2006, Rayner et al. 2010, McDermott 2014); yet the implementation in specific national settings is largely unresearched with few exceptions (McDermott et al. 2010). Implementation studies are called for to research the link between IFR-C and policy changes at the domestic level (Bernstein and Cashore 2012, Wibowo and Giessen 2012). In addition, only few studies have analyzed forest policy issues in Argentina (Rosenberg 2008, Gartland 2012, Romero 2012), but no research has been done on the implementation of the IFR-C in the country, with the exception of few studies analyzing particular issues of the regime (Espach 2006, Cubbage et al. 2010). Hence, the objective of this article is to identify the most relevant international forest-related policy issues in Argentina as well as the main actors and their positions towards these issues. Due to the large North-South extension and resulting ecological variations within Argentina, special attention shall be given to potential differences between the northern and southern parts of Argentina regarding the relevant issues. Consequently, our hypothesis is that elements of the IFR-C are made relevant in Argentinean policy by specific actors formulating their related positions in public and/or expert deliberations. Hence, the different interests of the most relevant actors will determine which forest issue elements become relevant at the domestic level. In addition, ecological and political differences at subnational levels lead to further differentiations in which forest issue elements become relevant in different regions of the country.

\section{METHODS}

Theoretical underpinnings. An international regime can be defined as a "set of implicit or explicit principles, norms, rules and procedures around which actors' expectations converge in a given area of international relations" (Krasner 1982). International forest-related negotiations continuously take place in multiple processes resulting in a body of international forest-related policy, which is referred to as an international forest regime-complex (Rayner et al. 2010, Giessen 2013, Giessen et al. 2014, McDermott 2014).This regime complex is composed by a set of elements which are directly or indirectly relevant for forests as an issue in global politics (Humphreys 1999, Giessen 2013). Thus, the IFR-C consists of different elements from a number of international regimes referred to as Forest Issue Elements (FIE). Analytically the IFR-C is a program consisting of goals, measures, assumed impacts and implementing actors (Krott 2005). Likewise each FIE consists of goals, measures, assumed impacts and implementing actors (Giessen
2013). Which and how each of these FIE are implemented or not at national level is different in each country and depends on problem structure, actors and the institutional setting (Bernstein and Cashore 2012). The relevance of the different FIE at a domestic level is influenced by the interests of the relevant domestic actors, be they state or non-state.

Interests of actors determine the actions they take, which is the reason why they constitute one of the most important factors in political processes (Krott 2005). Interests are not openly displayed based on different tactics (Krott 2005). Positions can be defined as the publically stated preferences towards specific policy or policy options. The different positions are based on the actors' interests (Wibowo and Giessen 2012).

When the various actors and their different forest-related interests are brought together, issues arise and become visible (Krott 2005). Such issues are then addressed in more or less public arenas, whereas low degree of publicity in general results in clearer articulation of positions.

Study area. Argentina has a continental area of 2,791,810 $\mathrm{km}^{2}$, with a length from north to south of $3,700 \mathrm{~km}$ between $22^{\circ}$ and $55^{\circ}$ of Latitude South. This extension determines a wide climatic variation, from subtropical conditions in the north with mean annual temperatures above $20{ }^{\circ} \mathrm{C}$ to temperate conditions in the south with mean annual temperatures below $10{ }^{\circ} \mathrm{C}$ (SAyDS 2010a).

There are around 31.4 million hectares of natural forests divided in six ecological regions (SAyDS 2005). Moreover, there are 1.2 million hectares of cultivated forests, $80 \%$ of which are located in the north-east of the country, in the Mesopotamian region (MAGyP 2013). At national level the Secretariat of Environment and Sustainable Development is responsible for natural forests, while the Ministry of Agriculture, Livestock and Fisheries is responsible for forest plantations. Argentina adopted a federal republican representative form of government. Except for national parks, which are under the jurisdiction of the national government, forests toile within the political responsibility of the provinces and are subject to provincial laws under the umbrella of national laws (Article 124 of the National Constitution 1994).

Due to climatic conditions, forests from the six ecological regions are very different, ranging from subtropical forests in the north to temperate forests in the south. The diverse conditions across these areas are assumed to lead to differences in the forest production and hence differences in actors and their interests. In order to analyze these differences two regions with completely opposite conditions were selected for analyses: the "Selva Paranaense" region, with 1.5 million hectares of natural subtropical forests in the north east of the country and the "Bosque Andino Patagonico" region with 1.9 million hectares of temperate forests in the south west (SAyDS 2005). The province of Misiones represents the "Selva Paranaense" ecoregion with only 40,000 ha of pristine forests, around $90 \%$ of degraded 
forests, between $23-26 \%$ of deforestation and only $8 \%$ of protected forests (Brown et al. 2006). Furthermore, this province held, until the year 2002, almost $35 \%$ of the plantation forests in the country contributing with $29 \%$ of the country's forest exports (Braier 2004). On the opposite side, the "Bosques Andino Patagónicos" ecoregion has $34 \%$ of protected forests being the most conserved ecoregion in the country (Brown et al. 2006). This ecoregion held, until the year 2002, around $6 \%$ of the plantation forests in the country (Braier 2004). From this ecoregion, the province of Río Negro was chosen -because of its long history in conservation having the oldest national park of the country- with the aim of comparing a highly forestry productive oriented province like Misiones with a highly conservation oriented province.

Empirical methods. Qualitative content analysis is a flexible method for analyzing text data (Neuman 2005). This method focuses on the language as a means of communicating with attention to the content of a text (Neuman 2005). It is the most appropriate method for objectively revealing the most significant text, word or symbol from a large volume of text (Neuman 2005, Sadath et al. 2013). This method has been widely used in political sciences to analyze documents and interviews (Neuman 2005).

In order to identify the most relevant international forest issues in Argentina, a qualitative content analysis was used in a two stage approach, distinguishing between public and expert sources in both stages. The distinction between these two types of sources lies on the degree of publicity. Public sources were defined as all material accessible to the whole population including newspapers and websites. Expert sources were defined as all material focused on a selected audience from the forest sector.

For the public sources, the first stage consisted of an open search in a broadly distributed national newspaper (La Nación) that was selected for eliciting the relevant issues. The terms "international", "forest" and "forestry" were searched with the search engine of the newspaper between the years 2008 - 2012. For the expert sources, an open search on professional journals in the field of forestry (Argentina Forestal, Producción Forestal) was done. This first stage was done in order to detect the most relevant international forest issues in Argentina as well as the most relevant actors. The second stage, after main actors and issues were identified, included a more focused search. For public sources, websites and position papers of the different actors towards the identified issues were searched. For expert sources, interviews to people with broad knowledge of the forest sector in Argentina through personal correspondence were made (table 1). To each one of them a question was made: Which international forest policy issues were relevant in Argentina between the years $2008-2012$ ? Interviews were used as an additional source to verify the data from other sources (Wibowo and Giessen 2012). The selection of the interviewees was based on their knowledge of the forest sector as well as on ease of field access.

In the analysis, forest-relevant actors were classified according to Krott (2005) into forest users (forest owners, forest workers and employees, general population), associations and parties (forestry associations, environmental NGOs) and government and administration bureaucracies.

For the North - South comparison, the two stage search was also applied in the two selected provinces. For the first stage in public sources, provincial newspapers widely distributed throughout the studied provinces were chosen (Misiones online for Misiones and Río Negro for Río Negro). For expert sources, the same professional journals used for the national level were used for both provinces but only articles of provincial relevance were selected at this level.

\section{RESULTS}

After analyzing all the sources found, seven Forest Issue Elements (FIE) were identified as relevant in Argentina. These FIEs were made relevant by different actors (table 2).

Table 1. List of experts interviewed. Listado de expertos entrevistados.

\begin{tabular}{|c|c|c|}
\hline Expert & Affiliation & Date \\
\hline Interview 1 & Officer, Ministry of Agriculture, Livestock and Fishery & November 27, 2012 \\
\hline Interview 2 & Officer, Ministry of Agriculture, Livestock and Fishery & November 21,2012 \\
\hline Interview 3 & $\begin{array}{l}\text { Researcher at Centro Austral de Investigaciones Científicas - Consejo } \\
\text { Nacional de Investigaciones Científicas y Técnicas }\end{array}$ & November 21, 2012 \\
\hline Interview 4 & Technician at the National Parks Administration. Patagonian Delegation & November 23, 2012 \\
\hline Interview 5 & Senior researcher at National Institute for Agricultural Research, Santa Cruz & November 22, 2012 \\
\hline Interview 6 & $\begin{array}{l}\text { Senior researcher at National Institute for Agricultural Research, Montecarlo, } \\
\text { Misiones }\end{array}$ & September 19, 2012 \\
\hline Interview 7 & Member of the Forest Engineers Association Misiones. & February 17, 2013 \\
\hline
\end{tabular}




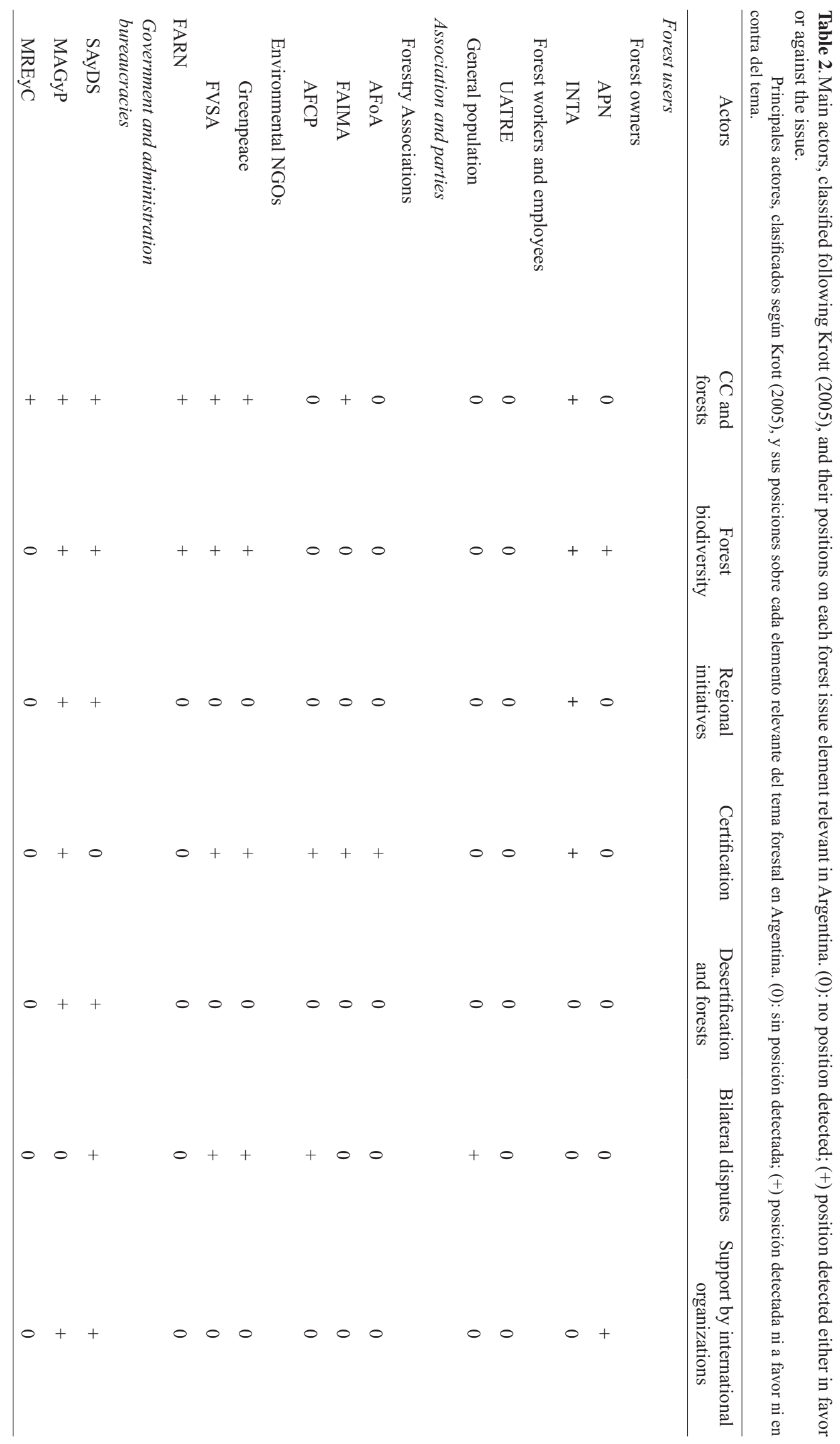


Climate change and forests. Since 1992, when countries joined the United Nations Framework Convention on Climate Change (UNFCCC), climate change has been an important issue in the international forest regime (Humphreys 2006). As a result of this convention, the Kyoto Protocol was adopted in 1997 entering into force in 2005.

Argentina approved the UNFCCC and the Kyoto Protocol by national law establishing the Secretariat of Environment and Sustainable Development as the application authority (Law 24295, Decree 2213/02). In 2005 the Argentinean Carbon Fund was created with the objective of facilitating and promoting Clean Development Mechanisms (CDM) projects in Argentina. The Ministry of Agriculture, Livestock and Fisheries supports the use of fast growing plantations as very efficient carbon sinks that can contribute to fight climate change (MAGyP 2013). However, environmental NGOs argue against the use of forest plantations as CDM projects (Greenpeace 2000). And finally, a national REDD strategy is at the moment under development (Colombres 2009) and discussed by different actors (FVSA 2010a, Greenpeace 2012).

Forest biodiversity. The Convention on Biological Diversity (CBD) addresses forests directly through the expanded program of work on forest biological diversity (annex to decision VI/22), adopted in 2002 (CBD 2013).

Argentina approved the CBD by national law and established a committee to follow up the convention, developing a national strategy about biological diversity (Law 24375, Decree 1347/97). At the moment the Nagoya Protocol on access to genetic resources and the fair and equitable sharing of benefits arising from their utilization, after being translated to the languages of the main ethnic groups from the country (SAyDS 2012a), is in the process of being ratified by the government (table 1: Interview 1). However, Argentina is not a party of the Cartagena Protocol on Biosafety. Argentina ranked $12^{\text {th }}$ in the export of commodities in 2002 due to the export of soybean cake and in the year 2006 was the second world producer of genetically modified organisms (ASA 2006). Therefore, most private sectors opposed the ratification of this Protocol (De las Carreras 2004).

Regional policy initiatives. After the first UNCED Rio Summit (1992), some regional initiatives towards defining and implementing sustainable forest management were initiated. Part of these initiatives which are relevant to Argentina include the Montreal Process on the definition of criteria and indicators for sustainable management of temperate forests, the Latin American and Caribbean Forestry Commission that works as a forum for Latin American countries to analyze important regional forestry issues and to exchange knowledge and expertise (FAO 2013) and the International Model Forest Network that has the goal of sustainable management of forest-based landscapes through the Model Forest approach (IMFN 2013).
Argentina has been very active in the last decade in the execution of different technical cooperation projects in terms of information systems, forest sanity and forest management as part of the activities in the Latin American and Caribbean Forestry Commission (table 1: Interview 2). In 2002 the national working group for the Montreal Process was created by the Secretariat of Environment and Sustainable Development, also involving the Ministry of Agriculture, Livestock and Fisheries, the National Institute on Agricultural Technology (INTA) and the National Park Administration. The criteria and indicators formulated under the Montreal Process were then used in the forests associated to the IMFN. There are currently six forests associated to the IMFN adding up to 6,798,000 ha (Programa Nacional de Bosques Modelo 2013).

Competing forest certification schemes. Forest management certification was introduced as a market based instrument mainly promoted by environmental NGOs which realized about the need for a tool -stronger than international conventions- to stop deforestation and promote sustainable forest management. Moreover, to stop timber illegality, legality certification schemes have lately been developed.

In January 2013 there were 305,137 ha of forests in Argentina certified by FSC (FSC 2013), mainly forest plantations with only two companies certifying the management of natural forests. In 2010 a national certification scheme was lunched, after five years of development, following international requirements in order to be a part of PEFC (Testa 2010). A forest trade network based on the Global Forest and Trade Network is currently being promoted both by environmental NGOs as well as by forestry associations to deal with illegally harvested timber, which is estimated to be around $30 \%$ of the total volume commercialized from the country (FAIMA 2012a, FVSA 2013).

Desertification and forests. Similar to climate change and biodiversity loss, desertification was identified as an important issue at the 1992 Rio Earth Summit, and the United Nations Convention to Combat Desertification (UNCCD) was established in 1994 (UNCCD 2013).

In Argentina there are 60 million hectares suffering from erosion. The area is expanding at a rate of 650,000 hectares per year by degradation and desertification of land (SAyDS 2013) with $75 \%$ of the land cover under some process of degradation (SAyDS 1997). In 1996, Argentina ratified the UNCCD by national law and proposed a National Action Program as well as Sub-Regional Programs (SAyDS 1997). Forest plantations are seen as a solution to stop desertification and subsidies, such as the exemption of taxes, have been granted by the Ministry of Agriculture, Livestock and Fisheries, to promote them with the intention of protecting the soil from desertification processes (MAGyP 2013).

Bilateral forest related disputes. Over the years several issues concerning forests and forest industry became impor- 
tant inter-national issues between Argentina and specific neighbor countries such as Uruguay and Chile. In the last years, an important conflict between Argentina and Uruguay over the installation of a pulp mill over the margins of the Uruguay River, boundary between both countries, has developed. The conflict started with demonstrations in the Argentinean town of Gualeguaychu where the general population organized under an assembly (Asamblea Ciudadana Ambiental Gualeguaychu) claiming that the pulp mill had negative impacts on the environment and that its installation violated the Statute of the Uruguay River from 1975 (Sarlo 2010). The conflict later rose to the level of the foreign ministries of both countries ${ }^{1}$. A committee of the government of Argentina, led by the Ministry of International Affairs and Cult, then brought the issue to the International Court of Justice (table 1: Interview 3) who established that the Statute of the Uruguay River had not been violated by Uruguay and the pulp mill could operate ${ }^{2}$.

Another bilateral dispute took place between Chile and Argentina regarding the management of exotic invasive species like the beaver in the south of both countries. In 2001 , both countries started working in order to make an agreement to control the invasion of the beaver from the island of Tierra del Fuego into the continent. This work was done under the umbrella of the Argentina - Chile Environment Subcommittee (table 1: Interviews 3 and 4). In 2008, an agreement to stop the invasion of the beaver and to restore areas affected by this species was signed by both. In addition under the umbrella of the Environmental Treaty between Argentina and Chile from 1991, binational plans for forest fire prevention and control were developed (table 1: Interview 4).

Support by international organizations. There are several forest-related financing initiatives associated with International Organizations. The most relevant of these initiatives identified in Argentina are the Global Environment Facility (GEF) and the World Bank through the International Bank for Reconstruction and Development. So far, there have been 28 environmental projects financed by GEF in Argentina, two of which are entirely about forests (GEF 2013).

Forest owners. Argentinean forest plantations are owned mainly by private owners $(99.7 \%$ ) and only $0.3 \%$ is owned by state organizations (FAO 2010). The natural forests are owned by the National Parks Administration (3.5\%), the different provinces (approximately $2.9 \%$ ) as well as some research and environment protection institutions as National Universities and INTA $(0.1 \%)$ and private owners $(93.5 \%)$ (SIFAP 2013).

Gutiérrez O, C Céspedes-Payret, D Panario. Was the implementation of an Industrial Forestry Complex in Uruguay the result of a State Policy or Policy Transfer? Unpublished.

2 Idem
The National Parks Administration depends on the Ministry of Tourism and has the objective to protect and conserve the different ecosystems. One of their main goals is the conservation of biodiversity and the promotion of sustainable activities (SAyDS 2010a) and hence they are involved in the national strategy for biodiversity; however they are not involved in other international forest issues and have not taken any position. INTA is an autarchic organism dependent of the Ministry of Agriculture, Livestock and Fisheries. As a national institution they are concerned about many international forest issues. They have been working on the adaptation of forests to climate change and participating in international meetings about it (Surraco 2012) as well as in the formulation of the national strategy for biodiversity (SAyDS 2010a). They participated in the Montreal Process working on indicators of sustainable forest management (table 1: Interview 5). They claim the use of criteria and indicators is a useful tool for a country to evaluate how sustainable the management of the forests at a national level is. On the other hand, they stress the use of these criteria and indicators will improve the income of the forest, benefitting the forest industry by allowing access to new markets (table 1: Interview 5). They are working on the development of a certification scheme for natural forests that guarantees legality of the products as well as sustainable management of the forests (FAIMA 2012). Their aim is to have a certification scheme more accessible for forest owners, especially for small land owners, farm workers and aborigines' communities.

Forest workers and employees are represented by the same union as all rural workers, the Argentinean Union of Rural Workers and Stowers (UATRE), their rights and benefits are then looked after by this Union. Although they represent all forest workers in the country, they have not posed any position on issues of international forest policy.

Although the general population could not be identified as actors on international forest policy issues, they played an important role in the pulp mill conflict with Uruguay (Sarlo 2010). An assembly was formed against the installation of a pulp mill in Uruguay, making big demonstrations (Sarlo 2010).

Associations and parties. At a national level there are three forest associations. The Argentinean Forest Association (AFoA), created in 1946, groups companies, forest producers, students and independent professionals of the forest sector, its industry and associated services. They are concerned about productivity of forests and the commercialization of their products. They, both FSC and PEFC, understand forest certification as a means of entering markets, such as the EU, and hence are in support of certification initiatives (AFoA 2012). The Argentinean Federation of Wood and Related Industry (FAIMA) represents the forest industry sector, grouping 26 different associations from around the country (FAIMA 2013a). Their main interests are the commerce of wood and wood products. Regar- 
ding international forest issues, they support certification processes, both FSC and PEFC, also as means of entering foreign markets (FAIMA 2013b). Moreover, they claim a forest trade network in Argentina to stop timber illegality is needed, such as the one proposed by Fundación Vida Silvestre Argentina (FVSA) (FAIMA 2012a). They work towards the use of wood for construction claiming it is a mechanism to store $\mathrm{CO}_{2}$ helping to reduce emissions to stop climate change (FAIMA 2012b). The Association of Producers of Cellulose and Paper (AFCP) has grouped the main producers of pulp and paper in the country since 1932 (AFCP 2014). As well as the other forestry associations, their main interest is in forest certification, both FSC and PEFC, seeing it as a means of entering foreign markets (AFCP 2009). They are also interested in the bilateral dispute with Uruguay about the pulp mill (AFCP 2010).

There are several environmental NGOs involved in international forest issues. Although their main goal is conservation, they have different views of what this means and different approaches to achieve their goals. Among the most popular Environmental NGOs at a national level are FVSA, Greenpeace and Fundación Ambiente y Recursos Naturales (FARN).

Regarding climate change and forests, they all consider REDD + as a valuable and positive tool to stop deforestation though they all emphasize it is very important to guarantee environmental and social safeguards in order to avoid negative effects due to this mechanism (Sibielau 2011, Greenpeace 2012). Both Greenpeace and FVSA support a legally binding document for climate change not only to reduce emissions (including emissions from deforestation) but also to include the finance of developed countries for adaptability measures in developing countries. They call for developed countries to have the responsibility to mitigate emissions and finance solutions (FVSA 2009, Greenpeace 2011). FARN claims that the GRULAC (group of countries from Latin America and the Caribbean) was not a protagonist in the climate change negotiations, except Brazil that was always closer to the EU and the USA than to Latin-American countries, and did not have unified and strong opinions as a group (FARN 2011a).

Regarding CBD, FVSA considers it is very important to protect areas in order to preserve biodiversity and works towards the creation of new protected areas as well as more control in the existing ones (FVSA 2010b). Greenpeace claims there is a lack of commitment to include production criteria to stop tropical forests destruction to make way to plantations as raw material for biofuel. This way, European Union countries keep using biofuels produced in non-sustainable ways and producer countries keep using agriculture practices that destroy the environment (Greenpeace 2008). FARN, on the other hand, argues towards the finance of the ambitious biodiversity goals of Aichi and the Nagoya Protocol (FARN 2011b).

FVSA points out forest certification as an important issue, they are a member of the environmental chair of FSC international and between 2002 and 2006 were the contact organization for FSC in Argentina (FVSA 2012). As well, they work towards the creation of a forest trade network in Argentina based on the Global Forest and Trade Network to stop timber illegality (FVSA 2013). Greenpeace supports forest certification arguing that, in Argentina, it is the only means of assuring that companies are using environmental and social standards, providing the basis for an appropriate environmental management.

Both Greenpeace and FVSA strongly opposed the pulp mill in Uruguay (Greenpeace 2006a, FVSA 2006). Greenpeace joined the assembly in Gualeguaychu during demonstrations (Greenpeace 2006b). They argue against the construction of pulp mills, both in Argentina and in Uruguay, using old technologies and high environmental impacts and push for a binational plan of clean production (Greenpeace 2006a). FVSA claim that the conflict showed the need for more articulation between Argentina and Uruguay as well as the need of companies to adopt social responsibilities. They consider the pulp mill should have been located in a more appropriate location. They call for treatment systems as well as continuous monitoring to ensure the minimum environmental damage (FVSA 2006).

Government and administration bureaucracies. There are mainly three bureaucracies involved in international forest issues at national level.

- Natural forests are under the jurisdiction of the Secretariat of Environment and Sustainable Development. As part of their goals, they are responsible for evaluating $\mathrm{CDM}$ projects as well as making the REDD+ national strategy (SAyDS 2010b). About REDD+, they claim that this mechanism will require a level of capacities that most developing countries currently lack. Therefore, they highlight the need for timely and sufficient support from Annex I countries for capacity building activities. Further financing is requested including upfront financing. Concerning CDM, they claim baselines need to be updated periodically. In this regard, past efforts made by developing countries to improve performance in different economic sectors and subsectors of their economies should be recognized and incorporated into the baselines; hence, those developing countries could be in a position to sustain and deepen their mitigation efforts (SAyDS 2008). In relation to the pulp mill conflict with Uruguay, they were part of the committee in charge of presenting the issue in the International Court of Justice together with the Ministry of International Affairs and Cult, as well as developing an Environmental Monitoring Plan (SAyDS 2012b).

- Forest plantations, on the other hand, are under the jurisdiction of the Ministry of Agriculture, Livestock and Fishery. They are involved in CDM, Certification schemes as FSC and CerFoAr, UNFF and UNCCD. About $\mathrm{CDM}$, they claim that forests are important carbon sinks and may play an important role in the adaptation 
to climate change. They stress that fast growing plantations are very efficient carbon sinks and may contribute to fight climate change. Since studies showed that old growth forests stop fixing $\mathrm{CO}_{2}$, productive plantations are an environmental opportunity (MAGyP 2013). Regarding UNCCD, they believe forest plantations may help rehabilitate degraded lands and fight desertification. Reforestation can help recover degraded land by acting as wind barriers; thus helping absorb water and fixate soil plus being $\mathrm{CO}_{2}$ sinks fighting climate change (MAGyP 2013).

- The Ministry of International Affairs and Cult is also involved in international forest related issues, mainly by leading negotiations at the different conventions. They argue towards the differentiated obligations and responsibilities, calling for developed countries to stop transferring their responsibilities to developing countries and pushing them to provide public and genuine funds --to help mitigation and adaptation to climate change in developing countries-- as well as technologic transfer. They ask to participate in the elaboration of new technologies from the beginning. They argue against developed countries taking unilateral measures, based on climate change arguments, which block exports from developing countries (Taiana 2009). Concerning the bilateral conflict with Uruguay about the pulp mills, they were in charge of presenting the issue in the International Court of Justice against the construction of the pulp mill (SAyDS 2012b) claiming Uruguay violated the international treaty of the Uruguay River (Taiana 2006). They do not take active positions on the other international forest issues.

North - South discrepancies. When comparisons between a province from the north, Misiones, and a province from the south, Río Negro, were made, in order to investigate potential discrepancies due to ecological differences, a number of issues were observed as relevant. While in the south, forest certification processes are not a main issue, in the north, consulted experts see certification as the most relevant international issue (table 1: Interviews 6 and 7), with the main consequence of improving working conditions for forest workers (table 1: Interview 6, Cubbage et al. 2010). The north east region of Argentina holds $80 \%$ of the forest plantations of the country mainly owned by big firms which are concerned about access to international markets and which can afford forest certification processes, while in the south, forests are owned mainly by smallholders who cannot afford these processes.

Although both, in the north and in the south, climate change is an issue, in the south the main topic is adaptation to climate change while in the north there is an interest in mitigation with CDM projects as well as many expectations around REDD. INTA has been researching the impact of climate change both on native as well as cultivated forests in the south of the country (Varela et al. 2013). On the other hand, the Ministry of Ecology of Misiones represented Argentina in meetings both in UN-REDD and FCPF, showing the collaboration between the national and provincial level. In these meetings they highlighted the importance of federalism in the country, and how this should be respected when applying REDD + mechanisms. The north of the country is more production-oriented and mitigation practices are used to justify more production. On the other hand, the south is more conservation-oriented, hence the adaptation measures.

Moreover, in the south one of the most relevant international forest related issues is the bilateral disputes with Chile about the invasion of exotic species, as the beaver, and the control of forest fires. Although the beaver is not currently a problem in the province of Río Negro, joint efforts with Chile have been made to stop the beaver from moving from the island of Tierra del Fuego into the continent. This effort is being done by all provinces from the "Bosques Andino Patagonicos" ecoregion (Table 1: Interviews 3 and 4). However, this is not an issue in the north.

\section{DISCUSSION}

The most relevant international forest policy issues of the past five years in Argentina were identified using qualitative content analyses of documents and interviews. According to our findings seven issues from the IFR-C were made relevant in Argentina by contrasting positions of different actors. The issues detected were not the same as the relevant subjects found in a similar study conducted in Indonesia (Wibowo and Giessen 2012), although climate change and forest certification were relevant in both countries. Previous studies in Argentina only focused on forest certification and its impact on forest sustainability (Cubbage et al. 2010). However, no analysis of the IFR$\mathrm{C}$ or other issues was done before. Studies on the implementation of the IFR-C are very important to understand the influence and effects of the different issues at national level (Lindstad and Solberg 2010, Bernstein and Cashore 2012); though, not much is known. Many attempts have been made to measure the effectiveness of the IFR-C (Hovi et al. 2003, Young 2003, Sprinz 2005). However, due to the fragmented nature of the IFR-C (Giessen 2013) in order to understand the effects of the IFR-C, a shift to influence-oriented studies is needed (Bernstein and Cashore 2012), which should be built on a theory-based, yet empirically applicable, understanding of the relevant actors' power resources (Krott et al. 2013).

Domestic actors are important in shaping the international forest related issues and their uptake at national level, depending on their interests (Giessen 2013). According to Hofmann (2002), in federal systems, as the one in Argentina, national bureaucracies benefit by gaining influence through the implementation of the IFR-C. As a result national bureaucracies dealing with forests become very competitive (Giessen 2013, Giessen et al. 2014) 
within national bureaucracies but also with subnational bureaucracies. Our results support this, with national bureaucracies, as the Ministry of Agriculture, Livestock and Fisheries and the Secretariat of Environment and Sustainable Development, having different positions towards some of the different issues. However, regarding some issues they seem to work together. This may be surprising since according to the bureaucratic politics theory only a single actor has a dominant role in a particular sector (Peters 2010). Similar results were found in Indonesia (Wibowo and Giessen 2012). Our analyses focused on public positions. Different results might be observed when analyzing ongoing politics. Based on the amount of issues, each actor had a public position; the most active actors were the environmental NGOs, which had public positions about most of the issues. However, the Secretariat of Environment and Sustainable Development was the most relevant actor, considering it is involved in the implementation of all the issues detected. This result shows the significance of main bureaucracies in dealing with international forest issues in Argentina as suggested by the bureaucratic politics theory (Peters 2010).

When analyzing the subnational level in two provinces with different ecological conditions, discrepancies were detected especially regarding forest certification. Surprisingly, no discrepancy between the north and the south was detected regarding desertification. Considering the climatic conditions of the south and the long term impacts predicted to this area due to climate change, we expected desertification to be a main issue for this area. However, no differences were observed concerning this issue. The results of the subnational levels show that it is politically worthwhile to account for ecological variations in policy analyses because they lead to different incentives and production patterns.

Our methodology did not detect deforestation or soy bean expansion as an international forest related issue despite being a central question in the country (Pengue 2005, Leguizamón 2014). The selection of broadly distributed newspapers, both at the national and provincial level, as a first stage in the search of public sources can cause potential biases by two selection processes. Firstly, the selection of the sources by the authors may lead to a bias. Secondly, media selection processes can influence forest discourses (Sadath et al.2013). The same limitations apply to our selection of the professional journals. The scope of the chosen media and the expected interest of the audience could explain the issues they discuss (Sadath et al. 2013). However the issues discussed in the public sources were only used as a first step in the analyses. The use of other sources allowed the minimization of this bias. Our methodology focused on the position of the different actors on the diverse issues relevant in Argentina. However, the issues which are not made relevant and the reason why they are not made relevant cannot be detected by our methodology. Future analyses focusing on this should be carried out to further explain the implementation of the IFR-C in Argentina.

\section{CONCLUSIONS}

The different actors identified in this study showed opposing positions towards the different forest issue elements from the forest regime complex. The major differences in positions were observed between environmental NGOs and the Secretariat of Environment and Sustainable Development and the Ministry of Agriculture, Livestock and Fisheries. These differences in the interests of the main actors determined which forest issue elements are actively made relevant in Argentina. Climate change and forests was detected as the issue that presented the most opposing positions. At subnational level, a number of forest issues were observed as relevant, most likely due to ecological and political differences.

\section{ACKNOWLEDGEMENTS}

This research was supported by funding from the Eva Mayr-Stihl Foundation, the German Research Foundation (DFG PAK 813) and Erasmus Mundus Action 2 EUROPLATA partnerships.

\section{REFERENCES}

Bernstein S, B Cashore. 2012. Complex Global Governance and Domestic Policies: Four Pathways of Influence. International Affairs 88(3):585-604.

Braier G. 2004. Tendencias y Perspectivas del Sector Forestal al año 2020. Informe Nacional $N^{o} 1$. Secretaría de Ambiente y Desarrollo Sustentable. SAGPyA. Rome, Italy. FAO. 71 p.

Brown A, U Martinez Ortiz, M Acerbi, J Corcuera. eds. 2006. La Situación Ambiental Argentina 2005. Buenos Aires, Argentina. Fundación Vida Silvestre. 587 p.

Cubbage F, D Diaz, P Yapura, F Dube. 2010. Impacts of forest management certification in Argentina and Chile. Forest Policy and Economics 12(7): 497-504.

Espach R. 2006. When is Sustainable Forestry Sustainable? The Forest Stewardship Council in Argentina and Brazil. Global Environmental Politics 6 (2): 55-84. doi:10.1162/ glep.2006.6.2.55

Gartland HM. 2012. Política y legislación forestales. Buenos Aires, Argentina. Hemisferio Sur.419 p.

Giessen L. 2013. Reviewing the Main Characteristics of the International Foret Regime Complex and Partial Explanation for its Fragmentation. International Forestry Review 15(1):60-70.

Giessen L, M Krott, T Möllmann. 2014. Increasing representation of states by utilitarian as compared to environmental bureaucracies in international forest and forest-environmental policy negotiations. Forest Policy and Economics 38: 97-104.

Hofmann F. 2002. Globale Waldpolitik in Deutschland - Eine Untersuchung über die Wirkung internationaler Regime in föderalen Strukturen. PhD Thesis. Albert-Ludwigs-Universität Freiburg. 311 p.

Hovi J, DF Sprinz, A Underdal. 2003. Regime Effectiveness and the Oslo-Potsdam Solution: A Rejoinder to Oran Young. Global Environmental Politics 3(3): 105-107. 
Howlett M, M Ramesh. 1995. Studying Public Policy: Policy Cycles and Policy Subsystems. 2nd edition. Toronto, Canada. Oxford University Press. $239 \mathrm{p}$

Humphreys D. 1999. The evolving forests regime. Global Environmental Change 9(3): 251-254.

Humphreys D. 2006.Logjam: Deforestation and the Crisis of Global Governance. London, UK. Earthscan. 139 p.

Krasner SD. 1982. Structural Causes and Regime Consequences: Regimes as Intervening Variables. International Organization 36(2): 185-205.

Krott M. 2005. Forest policy analysis. Dordrecht, The Netherlands. Kluwer Academic Publishers. 334p.

Krott M, A Bader, C Schusser, RRDevkota, A Maryudi, L Giessen, H Aurenhammer. 2013. Actor-centred power: The driving force in decentralised community based forest governance. Forest Policy and Economics. In press. doi. org/10.1016/j.forpol.2013.04.012

Leguizamón A. 2014. Modifying Argentina: GM soy and socioenvironmental change. Geoforum 53: 149-160.

Lindstad BH, B Solberg. 2010. Challenges in Determining National Effects of International Policy Processes: Forest Protection in Norway as a Case.Forest Policy and Economics 12(7): 489-496.

McDermott CL. 2014. REDDuced: From sustainability to legality to units of carbon-The search for common interests in international forest governance. Environmental Science \& Policy 35: 12-19.

McDermott CL, B Cashore, P Kanowski. 2010. Global Environmental Forest Policies: An International Comparison. London, UK. Earthscan. 392 p.

Neuman WL. 2005. Social research methods. Quantitative and qualitative approaches. 6th ed. London, UK Allyn and Bacon. $600 \mathrm{p}$.

Pengue WA. 2005. Transgenic crops in Argentina: the ecological and social debt. Bulletin of Science, Technology \& Society 25: 314-322.

Peters BG. 2010. The Politics of Bureaucracy-An Introduction to Comparative Public Administration. 6th edition. Oxford, UK. Routledge. $380 \mathrm{p}$.

Rayner J, A Buck, P Katila. Eds. 2010. Embracing Complexity: Meeting the Challenges of International forest Governance. A Global Assessment Report. Prepared by the Global Forest Expert Panel on the International Forest Regime. Vienna, Austria. IUFRO World Series Volume 28. 172 p.

Romero JE. 2012. Forest conservation in Argentina: Early analysis of the forest law implementation in the chaco ecoregion. Master Thesis. British Columbia, USA. University British Columbia. $123 \mathrm{p}$.

Rosenberg G. 2008. El concepto de bosque en la legislación argentina y en la normativa internacional. Recordip 1: 1-6

Sadath N, D Kleinschmit, L Giessen. 2013. Framing the tiger A biodiversity concern in national and international media reporting. Forest Policy and Economics 36: 37-41.

Sprinz D. 2005. Regime effectiveness: The next wave of research. Conference on the Human Dimensions of Global Environmental Change. Berlin, Germany.Volkswagen Found. 18 p.

Wibowo A, L Giessen. 2012. Identifying International ForestRelated Issues in Indonesia Based on Actors' Statements in Public and Expert Deliberations. International Journal of Social Forestry 5: 1-30.

Young OR. 2003. Determining Regime Effectiveness: A Com- mentary on the Oslo-Potsdam Solution. Global Environmental Politics 3: 97-104.

\section{EMPIRICAL REFERENCES}

AFCP (Asociación de Fabricantes de Celulosa y Papel, AR). 2009. La Asociación Civil FSC Argentina dio sus primeros pasos en la AFCP: reunió a empresas, sindicatos y ONG. AFCP Noticias $\mathrm{N}^{\circ} 46$.

AFCP (Asociación de Fabricantes de Celulosa y Papel, AR). 2010. Fallo de la Corte de La Haya sobre el diferendo entre la Argentina y Uruguay. AFCP Noticias $\mathrm{N}^{\circ} 61$.

AFCP (Asociación de Fabricantes de Celulosa y Papel, AR). 2014. Consulted 10 Apr 2014. Available in http://www. afcparg.org.ar/

AFoA (Asociación forestal argentina, AR). 2012. Consulted 27 Nov 2012. Available in http://www.afoa.org.ar/

ASA (Asociación Semilleros Argentinos, AR). 2006. Posición de ASA con respecto a la ratificación del Protocolo de Cartagena sobre Bioseguridad.

CBD (Convention on Biological Diversity, CA). 2013. Consulted 6 Feb 2013. Available in http://www.cbd.int/

Colombres M. 2009. El bosque, al rescate del planeta. La Nación, Buenos Aires, AR, oct. 24.

de las Carreras A. 2004. Bioseguridad, acuerdos y dudas. Buenos Aires, Argentina. La Nación, jan. 12

FAIMA (Federación Argentina de Industria Maderera y Afines, AR). 2012a. Buenos Aires - Una empresa certificada. Consulted 27 Nov 2012. Available in http://www.faima.org.ar/ content/view/2949/1/

FAIMA (Federación Argentina de Industria Maderera y Afines, AR). 2012b. Misiones - La madera con fuerte aporte para combatir el cambio climático. Consulted 27 Nov 2012. Available in http://www.faima.org.ar/content/view/2725/1/

FAIMA (Federación Argentina de Industria Maderera y Afines, AR). 2013a. Consulted 18 Jan 2013. Available in http:// www.faima.org.ar/

FAIMA (Federación Argentina de Industria Maderera y Afines, AR). 2013b. Empresas forestales del NEA obtendrían el se1lo internacional PEFC. Consulted 27 Nov 2012. Available in http://www.faima.org.ar/content/view/3096/1/

FAO (Food and Agriculture Organization of the United Nations, IT). 2010. Evaluación de los recursos forestales mundiales 2010. Informe Nacional. Argentina. Roma, Italia. FAO. 66 p

FAO (Food and Agriculture Organization, IT). 2013. Oficina regional de la FAO para America Latina y el Caribe. Consulted 19 Jan 2013. Available in http://www.rlc.fao.org

FARN (Fundación Ambiente y Recursos Naturales, AR). 2011a. COP 17 Durban: Conclusiones y prespectivas. Buenos Aires, Argentina. 10 p.

FARN (Fundación Ambiente y Recursos Naturales, AR). 2011b. Reporte sobre la $11^{\circ}$ Conferencia de las Partes Convenio sobre diversidad biológica. Buenos Aires, Argentina. 20 p.

FSC (Forest Stewardship Council, DE). 2013. Global FSC certificates: type and distribution. January 2013. Bonn, Germany. 18 p.

FVSA (Fundación Vida Silvestre Argentina, AR). 2006. Botnia y la situación de la industria de pulpa y papel en Argentina. Documento de posición. Buenos Aires, Argentina. 1 p.

FVSA (Fundación Vida Silvestre Argentina, AR). 2009. Financiar la adaptación es clave para un acuerdo climático en 
Copenhague. Buenos Aires, Argentina, dec. 14.

FVSA (Fundación Vida Silvestre Argentina, AR). 2010a. Una nueva oportunidad para hacerle frente al cambio climático. Buenos Aires, AR, nov. 30.

FVSA (Fundación Vida Silvestre Argentina, AR). 2010b. Hoy comienza el mayor encuentro internacional en el que los países definirán metas y políticas para conservar el medio ambiente global para los próximos 10 años. Buenos Aires, Argentina, oct. 18

FVSA (Fundación Vida Silvestre Argentina, AR). 2012. Consejo de Manejo Forestal. Consulted 25 Nov 2012. Available in http://www.vidasilvestre.org.ar/que_hacemos/nuestra_solucion/cambiar forma vivimos/conducta responsable/ bosques/_cual_es_la_solucion_/fsc/

FVSA (Fundación Vida Silvestre Argentina, AR). 2013. Red de Comercio Forestal Argentina. Consulted 25 Mar 2013. Available in http://www.vidasilvestre.org.ar/que_hacemos/ nuestra_solucion/cambiar_forma_vivimos/conducta_responsable/bosques/_cual_es_la_solucion_/red_de_comercio_forestal_argentina/

GEF (Global Envirnonment Facility, US). 2013. Consulted 25 Mar 2013. Available in http://www.thegef.org/gef

Greenpeace. 2000. ¿Deberían incluirse los Bosques y otras Actividades de Cambio en el Uso del Suelo en el MDL? Buenos Aires, Argentina. 27 p.

Greenpeace. 2006a. Greenpeace: "el gobierno argentino debe abandonar su política hipócrita en materia de plantas de celulosa". Buenos Aires, Argentina, jan. 13.

Greenpeace. 2006b. Greenpeace mantiene paralizada construcción de la papelera. Buenos Aires, Argentina, jan. 17.

Greenpeace. 2008. Documento de Greenpeace acerca de la Declaración de la Conferencia Mundial sobre Seguridad Alimentaria, Cambio Climático y Bioenergía de la FAO. Buenos Aires, Argentina, jun. 06.

Greenpeace. 2011. Documento posición de Greenpeace frente a la COP 17. Buenos Aires, Argentina, nov. 7 p.

Greenpeace. 2012. Los bosques y la gente primero: La necesidad de salvaguardas universales para REDD + . Amsterdam, NE. $24 \mathrm{p}$.

IMFN (International Model Forest Network, CA). 2013. Consulted $15 \mathrm{Feb}$ 2013. Available in http://www.imfn.net

MAGyP (Ministerio de agricultura, ganadería y pesca, AR). 2013. Área ambiental. Consulted 3 Feb 2013. Available in $\mathrm{http} / / / 64.76 .123 .202 / \mathrm{new} / 0-0 /$ forestacion/tecnica $\% 20$ e\%20informacion/08_Area\%20Ambiental/04_Acuerdos\%20Ambientales/index.php

Programa Nacional de Bosques Modelo, Argentina. 2013.Iniciativa de la red nacional de bosques modelo sobre criterios e indicadores de manejo forestal sustentable. Buenos Aires, AR. 52 p.

Sarlo B. 2010. Cronica de una derrota anunciada. La Nación, Buenos Aires, Argentina, apr. 25.
SAyDS (Secretaría de ambiente y desarrollo sustentable, AR). 1997. Programa de acción nacional de lucha contra la desertificación. República Argentina. Documento de base. Buenos Aires, AR. 55 p.

SAyDS (Secretaría de ambiente y desarrollo sustentable, AR). 2005. Primer inventario nacional de bosques nativos. Proyecto bosques nativos y áreas protegidas BIRF 4085-AR 1998-2005, Argentina. 126 p.

SAyDS (Secretaría de ambiente y desarrollo sustentable, AR). 2008. Republic of Argentina. Scope and content of the second review of the Kyoto Protocol pursuant to its Article 9. Buenos Aires, Argentina.

SAyDS (Secretaría de ambiente y desarrollo sustentable, AR). 2010a. Cuarto informe nacional, Republica Argentina. Convención sobre diversidad biológica. Buenos Aires, Argentina. $112 \mathrm{p}$.

SAyDS (Secretaría de ambiente y desarrollo sustentable, AR). 2010b. Argentina REDD. Readiness Plan Proposal. Buenos Aires, Argentina. 104 p.

SAyDS (Secretaría de ambiente y desarrollo sustentable, AR). 2012a. Ambiente reconoce los conocimientos ancestrales de los pueblos originarios para la preservación de la biodiversidad. Consulted 12 Dec 2012. Available in http://www. ambiente.gov.ar/?idarticulo $=10913$

SAyDS (Secretaría de ambiente y desarrollo sustentable, AR). 2012b. Historia de la demanda ante la Corte Internacional de Justicia. Consulted 12 Dec 2012. Available in http:// www.ambiente.gov.ar/?idarticulo $=8989$

SAyDS (Secretaría de ambiente y desarrollo sustentable, AR). 2013a. Programa de Acción Nacional de Lucha contra la Desertificación. Consulted 3 Feb 2013. Available in http:// www.ambiente.gob.ar/?idarticulo $=463$

Sibielau, A. 2011. El mecanismo REDD+: Informe ambiental anual 2011. FARN, Buenos Aires, Argentina. 467-489 p.

SIFAP (Sistema Federal de Áreas Protegidas, AR). 2013. Consulted 24 Jun 2013. Available inhttp://www2.medioambiente. gov.ar/sifap/default.asp

Surraco, C. 2012. Un representante del INTA participo del IV curso internacional "Adaptacion al cambio climatico". INTA Noticias, sep. 25.

Taiana J. 2006. Speech from the Chancellor J Taiana at the Assembly in Gualeguaychú. July 2006

Taiana J. 2009. Speech from the Chancellor J Taiana at the Climate Change Convention 2009, Copenhague, Dinamarca.

Testa A. 2010. Sello propio de certificacion forestal. Buenos Aires, Argentina. La Nación, jul. 24.

UNCCD (United Nations Convention to Combat Desertification). 2013. Consulted 24 Jun 2013. Available in http:// www.unced.int

Varela S, M Weigandt, J Villacide, J Corley, ML Suárez, M Amoroso. 2013. Desafíos que plantea el cambio climático en la Patagonia. Río Negro, Viedma, Argentina. may. 11. 

An International Journal

\section{Dismantling Comprehensive Forest Bureaucracies: Direct Access, the World Bank, Agricultural Interests, and Neoliberal Administrative Reform of Forest Policy in Argentina}

\section{Sarah L. Burns \& Lukas Giessen}

To cite this article: Sarah L. Burns \& Lukas Giessen (2016) Dismantling Comprehensive Forest Bureaucracies: Direct Access, the World Bank, Agricultural Interests, and Neoliberal Administrative Reform of Forest Policy in Argentina, Society \& Natural Resources, 29:4, 493-508, DOI: 10.1080/08941920.2015.1089608

To link to this article: http://dx.doi.org/10.1080/08941920.2015.1089608

Published online: 23 Nov 2015.

Submit your article to this journal $[7$

LII Article views: 42

Q View related articles

View Crossmark data $₫$

Citing articles: 2 View citing articles 둔 


\title{
Dismantling Comprehensive Forest Bureaucracies: Direct Access, the World Bank, Agricultural Interests, and Neoliberal Administrative Reform of Forest Policy in Argentina
}

\author{
Sarah L. Burns ${ }^{\mathrm{a}, \mathrm{b}}$ and Lukas Giessen ${ }^{\mathrm{a}}$ \\ ${ }^{a}$ Forest and Nature Conservation Policy, University of Göttingen, Göttingen, Germany; 'baboratorio de \\ Investigación de Sistemas Ecológicos y Ambientales, Universidad Nacional de La Plata, Facultad de Ciencias \\ Agrarias y Forestales, La Plata, Argentina
}

\begin{abstract}
By the end of the 1980s, Argentina was in the middle of a severe economic crisis. In 1991, the Deregulation Decree, which steered the political economy toward a new neoliberal policy, dismantled the Argentine National Forestry Institute (IFONA), an autonomous bureaucracy responsible for forests. The aim of this study is to analyze the influence the World Bank exerted on domestic forest policymaking and bureaucratic reform in Argentina. We selected the interventions of the World Bank in the Argentinian forest and agricultural policy that started in the early 1990s and still continues today. We use a qualitative case-study design building on content analysis of policy documents. The World Bank interventions through funding figured prominently, in the form of new forest laws that, as a whole, benefited plantation forests and regulated soy production expansion. This policy was found to be supported by a coalition of the World Bank, agricultural interests, and private landowners.
\end{abstract}

\section{ARTICLE HISTORY}

Received 11 April 2014

Accepted 26 July 2015

\section{KEYWORDS}

Agricultural coalitions;

bureaucratic politics; IFONA; international forest regime complex

\section{Introduction}

Since the Rio Summit in 1992, a growing number of international policies and regimes have evolved aiming to govern forests globally. This "set of implicit or explicit principles, norms, rules and decision-making procedures around which actors' expectations converge in a given area of international relations" (Krasner 1982, 186) can be described as an international forest regime complex (Humphreys 2006; Arts and Babili 2012; Giessen 2013). Such a regime complex, for influencing domestic policies at national levels, depends on international and especially domestic coalition partners (Humphreys 2006; Bernstein and Cashore 2012). These can include international as well as domestic state and nonstate actors. Special attention, however, must be paid to domestic bureaucracies, as they have to invite international actors due to sovereignty principles and in the domestic policymaking process they are instrumental in developing policies including also regulatory instruments.

A research program on international forest policy that examines the pathways and politics through which international institutions influence such domestic policy change is currently being developed (Arts and Babili 2012; Bernstein and Cashore 2012). The 
analysis of the interaction among international regimes, their actors, and domestic bureaucracies is especially crucial (Hogl, Nordbeck, and Kvarda 2009; McDermott, Cashore, and Kanowski 2010). It is in this interaction that the politics of competing bureaucracies in the acquisition of new tasks and responsibilities for implementation occur.

During the authoritarian regime that ended in 1983 in Argentina, the foreign debt multiplied sevenfold, increasing the importance of international creditors as political actors in the country (Carranza 2005). By the end of the 1980s, Argentina was in the middle of a severe economic crisis triggered by hyperinflation, when most of the powerful international banks in the country provoked a run on the local currency (Carranza 2005). As a solution to this crisis, the neoliberal economic reforms demanded by international and domestic actors were applied (Carranza 2005; Tuozzo 2009), leading to a new agro-export policy. As in other Latin American countries, the World Bank played an important role in these reforms, increasing its presence and influence after the crisis (Tuozzo 2004; Silva et al. 2011). In the forest policy context, domestic agricultural bureaucracies invited the World Bank to assist in the development of the forestry sector, based on its potential for economic growth (Burns and Giessen 2014). This article argues that by inviting the World Bank, domestic bureaucracies sought funding from an international partner in order to increase their power vis-à-vis competing administrations, and in this way formed coalitions with the World Bank.

Considering this background, this article argues that in the midst the economic crisis of the early 1990s, a strong coalition of (agricultural and profit-oriented) bureaucracies and associations of private landowners (in forestry as well as agriculture) emerged, advocating national development based primarily on more profitable and productive land use. This led to a predisposition in favor of changes toward more profitable land uses and the respective supporting policies and administrative frameworks. These eventually resulted in dismantling the Argentine National Forestry Institute (IFONA), a rather strong and comprehensive forest bureaucracy, into weaker units, so as not to obstruct transformations to more profitable land uses such as timber plantations and soy production. In order to facilitate this process further, the domestic coalition was then enhanced by the presence of such international actors as the Food and Agriculture Organization (FAO) and, most prominently, the World Bank. This was in order to provide more support for these neoliberal developments by making concrete recommendations for policy development. Consequently, we argue, the World Bank played a crucial role upon joining and supporting the domestic coalition of pro-agriculture public and private actors.

Hence, the aim of this study is to analyze the influence of the World Bank on domestic forest policymaking, undermining forest bureaucracies and policy with a bias toward the agricultural sector in Argentina, by exploiting a historical cleavage of neoliberal domestic politics combined with bureaucratic competition among government agencies searching for broader missions and budgets. In order to perform this analysis we employ bureaucratic politics theory from policy analysis (Peters 2010), combined with the theorem of direct access from global governance theory (Bernstein and Cashore 2012). In so doing, this article poses the following main research question: How did a pro-agriculture coalition of international bureaucracies and strong national bureaucracies, together with their domestic allies, influence a full restructuring of administrative structures and policies affecting forestry in Argentina? 


\section{Theoretical Approach}

The means by which international regimes, such as the international forest regime complex, may exert their influence at the domestic level can be categorized into "four pathways of influence, each with its own causal logic: international rules; international norms and discourse; creation of or interventions in markets; and direct access to domestic policy processes" (Bernstein and Cashore 2012, 587). It is "the interaction of mechanisms and processes, sometimes along multiple pathways, that create[s] collective influence" (Bernstein and Cashore 2012, 603). However, the type of interlinkages is so far undertheorized, leading to one possible relation among pathways, that is, that discourses do not directly influence domestic policy making but rather prepare the way for other pathways to occur.

Taking the pathways individually, Bernstein and Cashore (2012) consider direct access as being the potentially strongest one; hence, this is the focus of this article. Direct access refers to the influence by means of direct funding, education, training, assistance, and capacity building (Bernstein and Cashore 2000; 2012). This pathway is linked to providing incentives to domestic policy actors, which, according to the theory of incentives (i.e., the principalagent model), can cause an actor's interest to change direction, and therefore functions as a critical power resource (Karsenty and Ongolo 2012; Krott et al. 2014). Although it represents a very important form of influence, this path can be described as one of "infiltration" in the domestic policymaking process (Bernstein and Cashore 2000). It is seen as intrusion and raises issues of sovereignty (Bernstein and Cashore 2012). As a consequence, direct access is most likely to occur with the support of specific domestic state actors who bring critical legitimacy to the process, which is essential in overcoming sovereignty concerns (Gulbrandsen 2003). In exchange, those domestic state actors who invite outside actors gain additional sources of power, such as legitimacy and financial resources (Peters 2010). In our analysis, these domestic state actors are defined as domestic bureaucracies.

A bureaucracy can be defined as "an agency that has been set up by governments or other public actors with some degree of permanence and coherence and beyond formal direct control of single national governments" (Biermann et al. 2009, 37). Bureaucratic politics theory claims that bureaucracies compete with each other for resources, staff, and responsibility for policy domains. This competition between bureaucracies with different preferences, abilities, and power capabilities shapes the resulting policy to a great degree (Peters 2010; Giessen, Krott, and Möllmann 2014). In their struggle for power, bureaucracies act in coalition with other public and private actors in fields where their interests (partly) overlap, trying to establish institutions in support of this shared interest. Being rather stable over time, this combination of shared interests and institutions is referred to as a policy sector, for example, as forestry or agriculture (Rayner et al. 2001). In joining forces, policy sectors attempt to influence public policy based on the overlapping portions of their interests. In order to influence domestic policies, international regimes' bureaucracies are likely to seek coalitions with national bureaucracies. These coalitions can sometimes give international bureaucracies the opportunity of having direct access to domestic policy change.

\section{Methodology}

\section{Case Description}

At the end of the 1980s, the newly elected President Menem designated the former VicePresident of Bunge \& Born (the largest multinational firm in Argentina, specialized in food 
Table 1. List of relevant regulations, their year, objectives, and implication for the administrative structure.

\begin{tabular}{|c|c|c|c|}
\hline Regulations & Year & Objectives & $\begin{array}{l}\text { Implications for } \\
\text { administrative structure }\end{array}$ \\
\hline Decree 2284 & 1991 & $\begin{array}{l}\text { Deregulation of the economy; dissolution of } \\
\text { regulatory bureaucracies }\end{array}$ & Dismantling of IFONA \\
\hline Law 24857 & 1997 & Fiscal stability for forest activity & Supporting SAGyP \\
\hline Law 25080 & 1999 & $\begin{array}{l}\text { Investment for forest incentives for plantation } \\
\text { forests }\end{array}$ & Supporting SAGyP \\
\hline Law 25509 & 2001 & $\begin{array}{l}\text { User rights; facilitate investments in plantation } \\
\text { forests without having to own the land }\end{array}$ & Supporting SAGyP \\
\hline Law 26331 & 2007 & $\begin{array}{l}\text { Native forests conservation through land-use } \\
\text { planning; creation of a fund }\end{array}$ & $\begin{array}{l}\text { Strengthening of the Directorate for } \\
\text { Native Forests }\end{array}$ \\
\hline Decree 1366 & 2009 & Creation of new ministries & $\begin{array}{l}\text { Establishment of the Ministry of } \\
\text { Agriculture }\end{array}$ \\
\hline
\end{tabular}

processing and grain and oilseed trade) as Finance Minister, as soon as he took office ${ }^{1}$ (Carranza 2005). This designation was one out of many ways of showing his intent to implement the neoliberal reforms demanded by international and domestic actors (Carranza 2005; Tuozzo 2009). These reforms were carried out under the Convertibility Plan, which aimed to end hyperinflation and promote growth in Argentina. In 1991, following the neoliberal discourse, the Deregulation Decree (Table 1) was signed, turning the political economy toward a neoliberal policy, tied to an agro-export policy ${ }^{2}$ (Carranza 2005; Leguizamón 2013). This decree aimed to promote trade by ending protective regulation of the domestic economy, dismantling all bureaucracies that were in charge of these activities and simplifying the tax system (Leguizamón 2013). In this process, the Argentine National Forestry Institute (IFONA), a comprehensive and autonomous bureaucracy responsible for all aspects of forests at a national level, accused of inefficiency and corruption (Interview 1, Interview 2, Table 2), was dismantled, dividing its functions and staff between four bureaucracies: (i) the newly created Directorate for Native Forests, responsible for native forests and contained within the also newly created Secretariat of Natural Resources and Human Environment; (ii) the Directorate for Forestry Production, responsible for forest plantations, timber processing industries, and agroforestry, and part of the Secretariat of Agriculture, Livestock and Fisheries; (iii) the National Parks Administration (APN), a semiautonomous agency within the Secretariat of Natural Resources, responsible for protected areas at the federal level; and (iv) the National Institute for Agricultural Research (INTA), a semiautonomous research and extension entity that includes a forestry research unit within the Secretariat of Agriculture (World Bank 1996) (Figure 1).

These market-friendly economic reforms were praised by international financial institutions and institutions of global governance, like the G-8 (Carranza 2005). This led to an increased presence and influence from the World Bank in the country, with the World Bank becoming a very important actor in the domestic reforms by diversifying its funding and by means of capacity building through knowledge (Tuozzo 2004).

The new agro-export policy was geared toward a few commodities for the export market (Leguizamón 2013), and increased competition for land between the

\footnotetext{
${ }^{1}$ Menem ratifica su plan de ajuste al nombrar a Nestor Rapanelli ministro de Economía. Diario El Pais, July 16, 1989. http:// elpais.com/diario/1989/07/16/internacional/616543211_850215.html.

${ }^{2}$ El predador. Diario Pagina 12, April 9, 2009. http://www.pagina12.com.ar/diario/elpais/subnotas/122647-39235-2009-04-05. html.
} 
Table 2. List of experts interviewed, IFONA: National forest institute.

\begin{tabular}{|c|c|c|}
\hline Expert & Affiliation & Date \\
\hline Interview 1 & Former officer, IFONA & February 14, 2014 \\
\hline Interview 2 & Former officer, IFONA & February 6, 2014 \\
\hline Interview 3 & Former officer, IFONA & February 13, 2014 \\
\hline Interview 4 & Former officer, IFONA & February 15, 2014 \\
\hline Interview 5 & Staff member, Asociacion Forestal Argentina & April 7, 2014 \\
\hline Interview 6 & Senior officer, Directorate for Native Forests, Secretariat of Environment & October 29, 2013 \\
\hline Interview 7 & $\begin{array}{l}\text { Former senior officer, Policy and Institutions Service, Forestry Department, Food } \\
\text { and Agriculture Organization }\end{array}$ & March 12, 2014 \\
\hline Interview 8 & $\begin{array}{l}\text { Senior officer, Native Forests and their Biodiversity component, Secretariat of } \\
\text { Environment }\end{array}$ & October 25, 2013 \\
\hline Interview 9 & Senior officer, Directorate for Forestry Production, Ministry of Agriculture & October 30, 2013 \\
\hline
\end{tabular}

agricultural and forest sectors. According to estimates made by IFONA, at that time there were approximately 35.2 million ha of natural forests and 760,000 ha of cultivated forests, representing 12.5 and $0.3 \%$ of the country's total land area, respectively (Denegri and Aguerre 1996). However, the forestry sector only represented about $2 \%$ of the gross domestic product (GDP) (Gartland 2012). In 1992, after IFONA was dismantled, the Secretariat of Agriculture requested that the World Bank conduct a review of the forestry sector, with the aim of narrowing the gap between existing and potential levels of production (World Bank 2007). By the year 2002, the area of plantation forests increased to 1.2 million ha (World Bank 2008), while the area of natural forests decreased to 31.4 million ha (Secretaría de ambiente y desarrollo sustentable Argentina [SAyDS] 2005). At the same time, agricultural exports increased $60 \%$ between the years

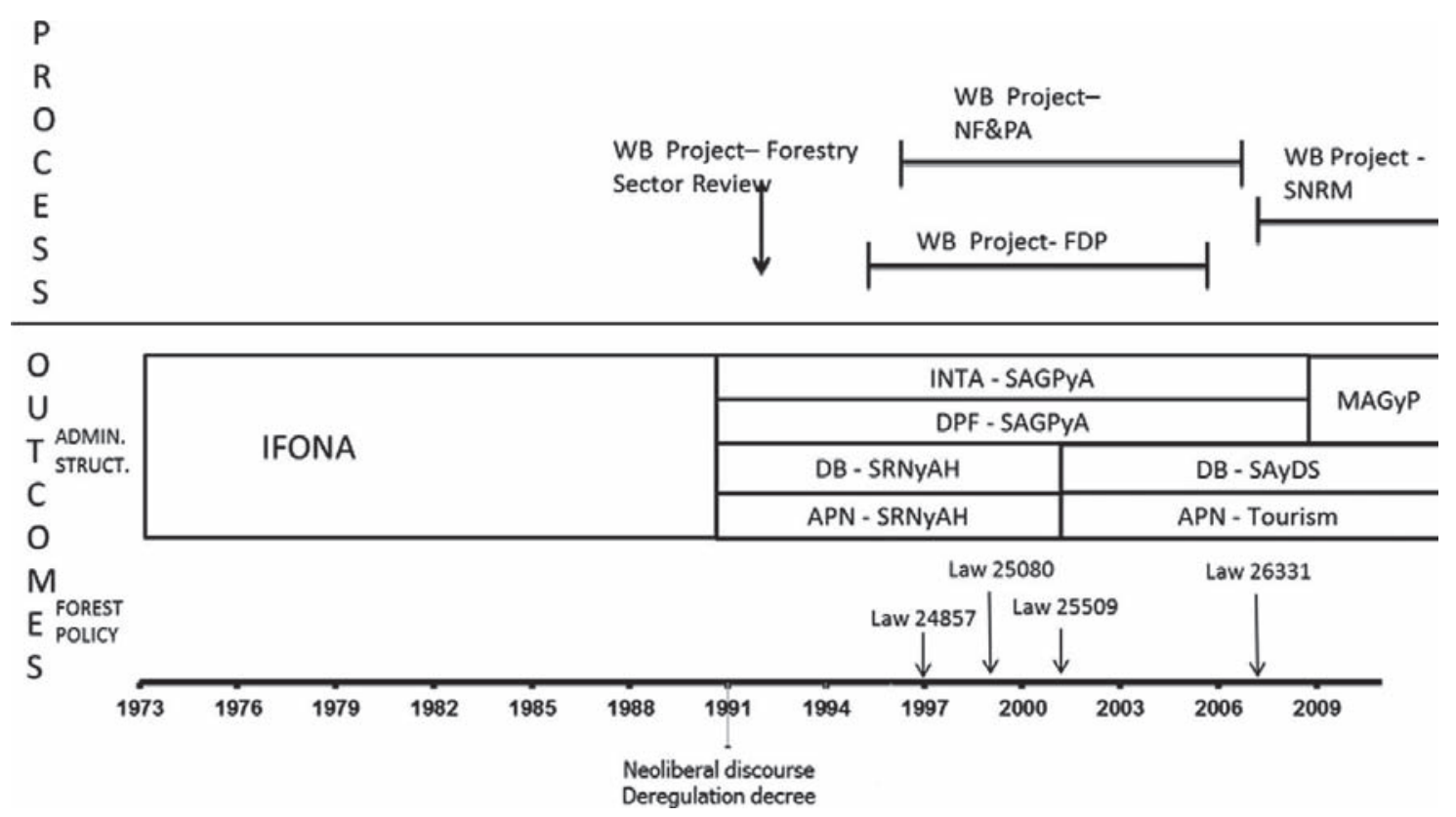

Figure 1. Process and outcomes over time. IFONA: National Forest Institute; INTA-SAGPyA: National Institute for Agricultural Research, Secretariat of Agriculture; DPF-SAGPyA: Directorate for Forestry Production, Secretariat of Agriculture; DB-SRNyAH: Directorate for Native Forests, Secretariat of Natural Resources and Human Environment; APN-SRNyAH: National Park Administration, Secretariat of Natural Resources and Human Environment; MAGyP: Ministry of Agriculture, Livestock and Fisheries; DB-SAyDS: Directorate for Native Forests, Secretariat of Environment and Sustainable Development. 
1990 and 1999, benefitting mainly big international oilseed firms (Teubal 2011). The five biggest companies accounted for $38.7 \%$ of the oilseed exports in 1990, whereas the proportion increased to $57.9 \%$ in 1998, and to $80 \%$ in 2002 (Teubal 2011). At that time, foreign companies appropriated large farms, and had bought around 16.6 million ha by the year 2005 (Pengue 2005).

These changes in the bureaucratic structure of forestry and the intervention of the World Bank through the funding of different projects in a sector competing with the agricultural sector make this an appropriate case for the study of the direct access pathway of influence exerted by international bureaucracies, domestic bureaucratic politics, and policy change.

\section{Empirical Methods}

To understand how the World Bank influences policy change through direct access, we conducted a qualitative case study of World Bank-funded forest projects and forest policymaking in Argentina from 1991 to the present. To do so, we employed process tracing (George and Bennett 2005). The method of process tracing "attempts to trace the links between possible causes and observed outcomes" (George and Bennett 2005, 6), focusing on sequential processes within a particular historical case. By providing theory-based historical explanations for a case, in which each significant step toward the outcome is explained by making reference to a theory, process tracing becomes a powerful method of inference (George and Bennett 2005, 30). We collected data from different sources with the aim of determining whether the direct access by international bureaucracies, together with competing national bureaucracies and national non-governmental organizations, can be related to the restructuring of the national forestry administration and forest policy change. As a first step, we completed a document search of publicly available sources to gather World Bank proposal documents and project completion reports from 1991 to the present. Using these documents, we identified executive bureaucracies involved in the projects. We then reviewed the websites of these bureaucracies to obtain published outputs of the projects. We subsequently conducted semistructured interviews with experts about the role and influence of international actors and domestic state and non-state actors in the process. Interviews lasted between a half hour and 2 hours. If it was not possible to meet with the interviewees in person, we used phone calls or e-mails. In all cases interviewees were promised confidentiality in order to ensure full disclosure (Koontz and Newig 2014). In total, we conducted nine interviews during October 2013 and April 2014 (Table 2). Seven interviewees came from domestic state agencies, one from domestic nonstate organizations, and one from the Food and Agriculture Organization. We used all the data collected for triangulation between documentary sources and all the interviews, providing valid and reliable data (Silva et al. 2011; Koontz and Newig 2014).

We used a qualitative content analysis method to analyze all documents and interviews (Neuman 2005). We coded the information obtained from the different data sources and grouped it into four main categories, based on the research objective. These categories were (i) administrative structure, (ii) policy content, (iii) project formulation, and (iv) project implementation. The outcomes (categories $\mathrm{i}$ and ii) and the process (categories iii and iv) were analyzed using these four categories. 


\section{Results}

In Argentina, the World Bank, as an international bureaucracy, by means of funding and capacity building, assisted the coalition of agricultural and profit-oriented bureaucracies and landowner associations (of forestry and agriculture) that emerged after the economic crisis at the beginning of the 1990s. By forming coalitions with the World Bank, certain bureaucratic units were able to increase their staff and budget and produce valuable information, thereby increasing their power. This agrees with our theory, in that international organizations can operate through the provision of funding and capacity building to assist the existing domestic coalitions of bureaucracies and associations in their constant competition for power, or to help create new ones. Because bureaucracies like the Secretariat of Agriculture and the Secretariat of Natural Resources were in permanent competition, they invited the World Bank with the aim of increasing their domestic power at the cost of their domestic competitors. This invitation led to the establishment of influence through direct access of the World Bank, as an international organization, on domestic forest policy and administration.

\section{The Politics of the World Bank Intervention Process}

At the end of the 1980s, IFONA invited the World Bank to fund a project to promote the forestry sector (Interview 1, Table 2). Negotiations began within IFONA, the World Bank, and FAO, and the "Forestry Sector and Environmental Protection Project" was conceived (World Bank 2006). However, the Deregulation Decree of 1991 dismantled IFONA as a comprehensive forest bureaucracy before the project started (Table 1), with the support of the Secretariat of Agriculture (Interview 1, Table 2). At the beginning, forest associations (e.g., AfoA, FAIMA, AFCP) did not assume a public position regarding the dismantling of IFONA (Interview 5, Table 2), although informal statements supported the measure, pointing out its inefficiency and corruption (Interview 1, Table 2). IFONA's functions and staff were then divided among four newly created bureaucracies (Interview 1, 2, 3 and 4, Table 2) that had to compete with each other for staff, resources and policy domain. A coalition with the World Bank, which involved funding accompanied by a high level of political support, would allow specific bureaucratic units to increase their staffs and budgets and to produce valuable information, thereby increasing their power.

After IFONA was dismantled, and with the challenge of promoting economic growth, the forestry sector was considered to hold the promise of potential for growth, mainly through plantation forests and by yielding land for soya production. The government, through the Secretariat of Agriculture, requested the World Bank to conduct a review of the sector in 1992 with the aim of narrowing the gap between existing and potential levels of production (Interview 7, Table 2, Table 3), which showed the forestry sector's increased productivity goals. As a result of this review, the national government, together with the World Bank and FAO, determined that the World Bank could provide significant assistance to "develop and implement an appropriate role of the national bureaucracies in forestry and conservation as part of their support for economy-wide policies and actions necessary for the improvement of Argentina's forestry potential" (World Bank 2006, 5). This led to the development of the first two forest projects, "Forestry Development Project" and "Native Forests and Protected Areas Project," with funding from the World Bank, 


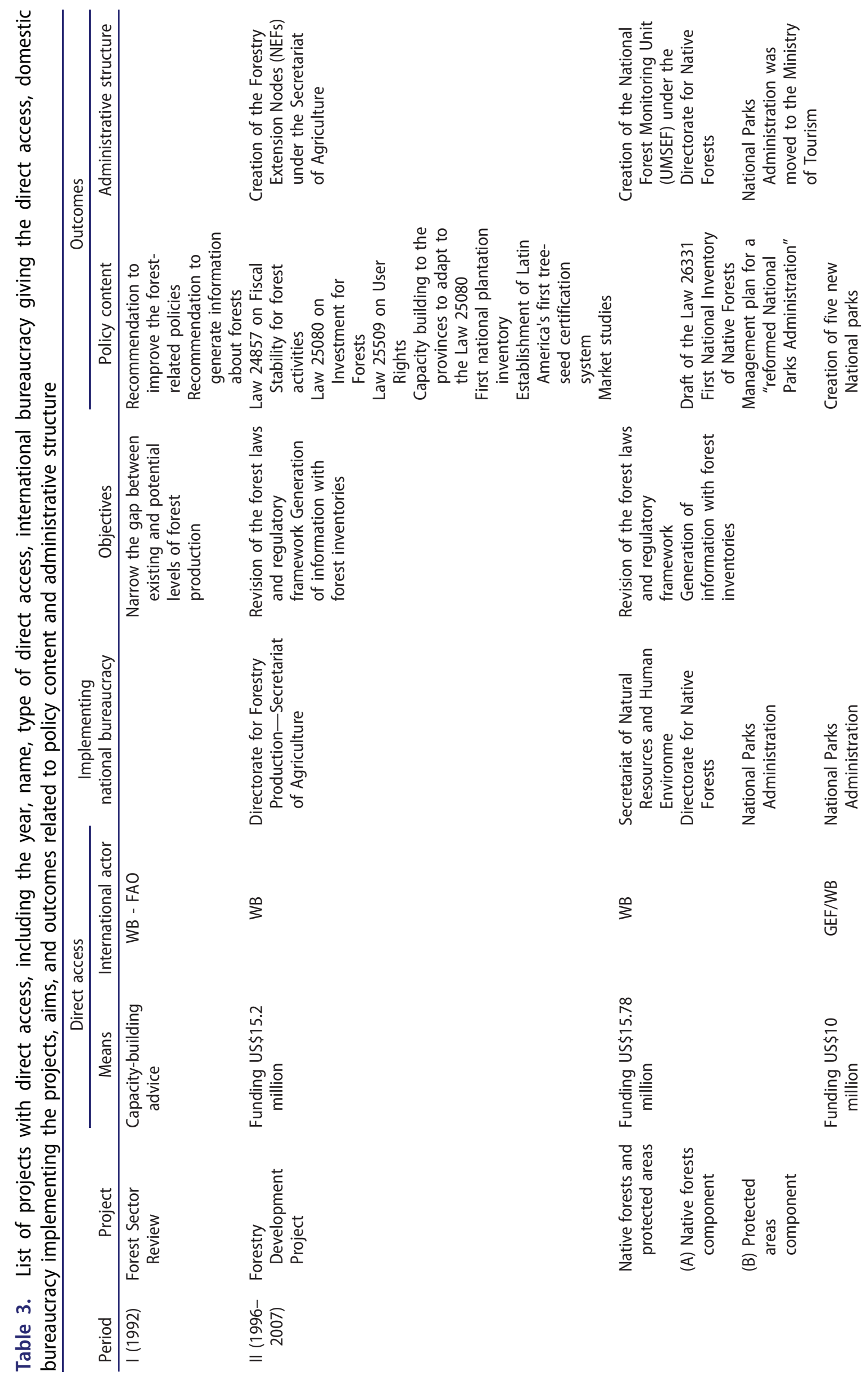



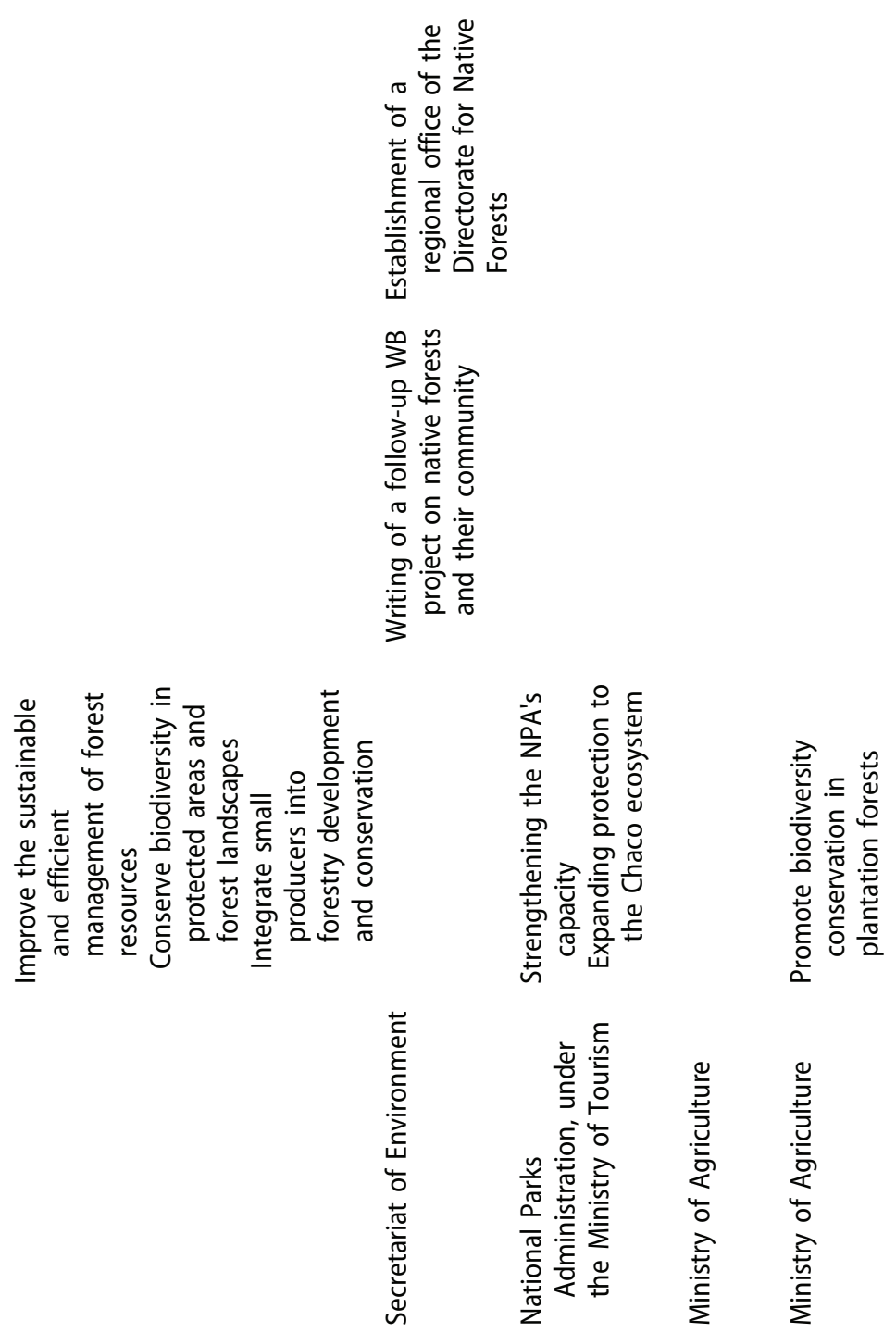

紧

$$
\sum_{\text {岀 }}^{\infty}
$$

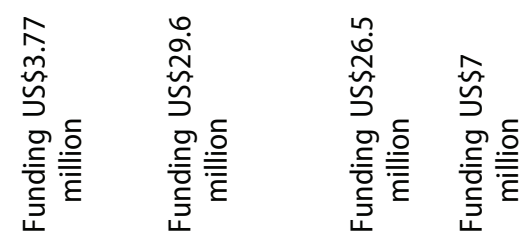

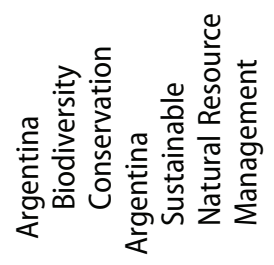

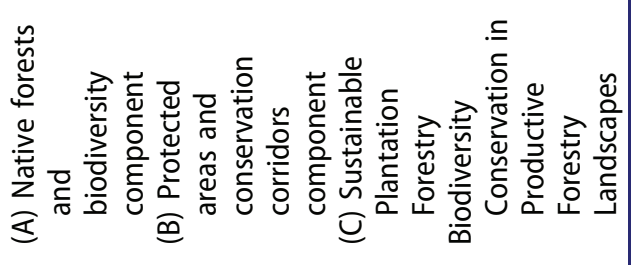

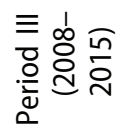

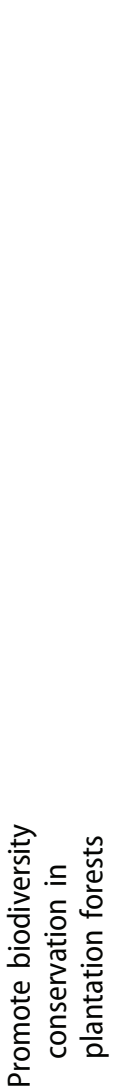


which praised the trade liberalization taking place at that time and stated that future policies should continue in this direction (World Bank 1995; 1996). At this time, the FAO-World Bank Cooperative Program, which involved technical experts from both the World Bank and FAO, played an important role through direct access by means of capacity building and by providing technical experts to assist in the project's formulation and supervision (Interview 7, Table 2; World Bank 2007). FAO technical experts, by providing technical expertise, preselect information and alternatives for political action, and by this preselection they increase their influence in the development of the projects. At this stage, foreign firms were identified, mainly from Chile, that were interested in investing in the Argentine forestry sector.

In 1996 and 1997 the first two projects were approved. They were implemented by different bureaucracies, and had as their main goal the revision of forest laws and regulatory framework, maintaining and deepening the reform processes taking place in Argentina at that time by means of persuasion, incentives (World Bank 1995; 1996), and the generation of information in the form of forest inventories (Table 3). At that time, the World Bank's forest strategy stipulated that funding of the forestry sector was "conditional on government commitment to sustainable and conservation-oriented forestry," which included an increase in production in plantation forests, shifting from native forests (World Bank 1991; Humphreys 2006). This strategy adopted a more preservationist and tougher approach to forest businesses, in comparison with the previous strategy from 1978 (Humphreys 2006).

Prior to the projects' completion, a third World Bank forestry project was proposed and later approved in 2008, the "Argentina Sustainable Natural Resource Management Project." This was to be implemented by three different bureaucracies, the Secretariat of Environment and Sustainable Development (SAyDS), the Ministry of Agriculture, Livestock and Fisheries (MAGyP) and the National Parks Administration (APN), with separate accounts and independent objectives, with a total funding from the World Bank of US\$60 million (Table 3).

\section{Losers and Winners of the World Bank Intervention Outcomes}

Policy. The "Forestry Development Project," implemented by the Directorate for Forestry Production, led to the creation of Law 24857 on Fiscal Stability for Forest Activity, Law 25080 on Investment for Forest Plantations, and Law 25509 on User Rights (World Bank 2006; Table 3). These laws had the aim of facilitating investments in plantation forests without having to own the corresponding land (Table 1). Unlike previous laws, these laws do not require the replantation of trees after trees are cut (Interview 1, Table 2). This meant that previously forested areas could now be converted to other land uses, like agriculture, which was not possible before. These changes increased investments in the forestry sector, reaching US\$2.9 billion between 1992 and 2013. Chilean companies made 66\% of these total investments, while the Directorate for Forestry Production invested $13 \%$, by means of incentives. ${ }^{3}$ The area of plantation forests increased from 760,000 ha in 1987 (Denegri and Aguerre 1996) to 1.2 million ha in 2002 (World Bank 2008).

${ }^{3}$ Valor Agregado, La industria maderera en cifras, Anuario 2014, Numero 13. 2014. 
An outcome of the "Native Forests and Protected Areas Project," implemented by the Secretariat of Natural Resources and Human Environment, through the Directorate for Native Forests and the National Parks Administration, was the drafting of new legislation on native forests (World Bank 2007). This led to the eventual approval of National Law 26331, which promotes the conservation of native forests through land-use planning (World Bank 2007; Table 1, Table 3). This law provides for "minimum standards" regulation, meaning that every province must reorganize its provincial laws in order to meet minimum federal requirements (Romero 2012). In addition, this law establishes three conservation categories for the native forests: Category I (red) includes high conservation value areas where no forest management is allowed; category II (yellow) is made up of medium conservation value areas subject to forest management with an approved sustainable forest management plan; and category III (green) comprises areas of low conservation value that can be converted into other land uses, like agriculture (similar Gartland 2012; Romero 2012).

The responsibility for the classification of the forests into these three categories lies with each corresponding province, which has to produce a map of its native forests, classifying their parts into the three conservation categories. Because the law allows the provinces a high level of discretion in its interpretation, the economic, social, and political context of each province will influence the way it implements this (Romero 2012). While the law provides ample leeway for promoting agriculture at the cost of native forests, it requires the planning of provincial native forestland use to be based on a participatory process that includes actors from outside the forest sector. Hence, strong policy sectors, like agriculture, were able to exert great influence on the results of the categorizations. ${ }^{4}$ This law opened the way to land use changes in the green areas, where native forests could now be converted into any one of other land uses, like agriculture, which provide provinces higher returns than the compensation received through conservation in red areas. By January 2013, 21 of the 23 provinces had finished and approved their provincial laws, including the corresponding map requested by the national law (Interview 6, Table 2). Of these 21 provinces, four were still waiting for national approval from the Directorate for Native Forests at that time.

The law also establishes a fund (Fondo Nacional para el Enriquecimiento y la Conservación de los Bosques Nativos) to compensate landowners (private or public) who preserve the native forests according to their conservation status (Romero 2012). The fund is to receive $2 \%$ of the agricultural export tax of primary and secondary agricultural products of each previous year, but no less than $0.3 \%$ of the general annual budget of the national government. According to the law, in 2012, 1.8 billion Argentinian pesos (US $\$ 400$ million) should have been destined to the fund for forest conservation $(70 \%$ for management plans and $30 \%$ for the national and provincial bureaucracies). However, only 250 million Argentinian pesos were actually given to this fund, approximately one-seventh of the established amount, showing the central government's commitment to this law (Interview 6, Table 2). In the period during which the bill was stalled in the Senate, environmental nongovernmental organizations (NGOs) and the major productive forestry sector organizations rallied to support it.

Another important outcome of the project was the realization of the First National Inventory of Native Forests (World Bank 2011; Table 3). The inventory has provided

${ }^{4}$ For further details on how this process took place, see Romero (2012). 
key data for the technical justification for the modification of the native forests law and an important instrument for its implementation (World Bank 2011). The ambitious definition of "native forest" used for the inventory, for example, excluded from the inventory a great part of the Monte ecoregion, where trees do not reach the altitude defined by the inventory. Therefore, these forests were not included in the area subject to categorization. In addition, the inventory would establish the patterns for future land use in these regions (World Bank 2011). The information produced by this inventory is also of great importance for the agricultural policy sector, since it strived to gather information on forests that could be transformed into agricultural uses.

In the year 2010, National Law 25080 was modified by Law 26432 to include, in one of its articles, that plantations are subject to the incentives only if their location is in accordance with what is established in the provincial maps of Law 26331 (Interview 9, Table 2). This means that, since the year 2010, the provinces have had to have their laws approved in order to get the incentives. This change in a law from the Ministry of Agriculture, as a consequence of a law from the Directorate for Native Forests, coincides with the theory proposed by Bernstein and Cashore (2012), which states that influence from international bureaucracies, through the provision of funding resources, could shift the power balance in domestic policy processes, benefitting marginalized or disempowered bureaucracies.

Administrative Reform. During the implementation of the "Native Forests and Protected Areas Project," a restructuring of the environmental national bureaucracies moved the National Parks Administration to the Ministry of Tourism (Figure 1). At that time, the Secretariat of Natural Resources was renamed as the Secretariat of Environment and Sustainable Development (SAyDS) (World Bank 2007).

As a result of the "Native Forests and Protected Areas Project," the National Forest Monitoring Unit (UMSEF) was created (World Bank 2007; Table 3) and was then absorbed by the Directorate for Native Forests, which now finances and supports it as an official forest monitoring service (World Bank 2011). Law 26331, implemented as a result of this project, strengthened the Directorate for Native Forests via the creation of the fund. This law established that $30 \%$ of the fund goes to the national and provincial bureaucracies, allowing this bureaucracy to more than double its staff in two years, from 20 to 50 employees (Interview 3, Table 2), increasing its power, at least in the short term.

In 2009, during the implementation of the Argentina Sustainable Natural Resource Management project, the Secretariat of Agriculture, until then within the Ministry of Economics, became the Ministry of Agriculture, Livestock and Fisheries (Table 1 and Figure 1). The bureaucratic status of the agricultural administration, acquiring independence from a strong bureaucracy like the Ministry of Economics, shows the increase in power achieved.

\section{Discussion and Conclusion}

Previous research on bureaucratic reform in Latin America focused mainly on domestic factors as explanatory variables, with only few studies analyzing the role of external influences (Tuozzo 2004; 2009). Our study supplements this research by focusing mainly on international influences, like the influence of the World Bank, as a complementary explanatory variable in the reform of the bureaucracy and policy of the forest sector that took place in Argentina. Our study shows that in Argentina, national forest bureaucracies 
have been weakened in relation to strong and emerging agricultural bureaucracies. By seeking assistance through funding from the World Bank, the bureaucracies of both native forests and plantation forests were able to increase their power, at least in the short term. However, agricultural bureaucracies were assisted by the World Bank at the same time and in greater amounts, receiving a total funding of US\$620 million between 1991 and 2015, as compared to the US\$102 million that the forestry sector received for the same period, half of which was also administered by the Secretariat of Agriculture. ${ }^{5}$ This search for assistance gave the World Bank the opportunity to gain direct access to the creation of policies that in the end promoted plantation forests and opened land for agricultural production. These results are in line with findings from the forest sector reform in Mali, where funding from the World Bank also resulted in a weakening of forest bureaucracies (Gautier et al. 2013), calling for a more systematic research on the declining power of forest bureaucracies due to an overarching neoliberal approach in international forest policy (Humphreys 2009).

After IFONA was dismantled, the Directorate for Native Forests, within the Secretariat of Environment, became the weakest forest bureaucracy. By forming a coalition with the World Bank, and with the support of environmental NGOs, the Directorate wrote a new law (Law 26331). This law granted this bureaucracy permanent funding from the national budget, which allowed it to double its staff after 2 years of implementation. In addition, this bureaucracy produced the first native forest inventory, in coalition with the World Bank, creating a new unit within the Directorate that would be in charge of the inventory and of monitoring the forest cover. The information produced with this inventory was of great utility for this bureaucracy at the time of implementation of the new law and of great importance for the agricultural policy sector, since it strived to gather information on forests that could be transformed into agricultural uses. These results are in line with the theory proposed by Bernstein and Cashore (2012) that states that influence from international bureaucracies through the provision of funding resources could shift the power balance in domestic policy processes, benefitting marginalized or disempowered bureaucracies. Weak bureaucracies, seeking to increase their power, invite and allow international bureaucracies to influence the policymaking process. Bernstein and Cashore (2012) also propose that by helping domestic bureaucracies enforce or implement their own laws by means of direct access, international bureaucracies are more likely to succeed than by passing new legislation. Our results show that in the Argentinian case, the World Bank was an ally in the formulation and implementation of new laws. However, these laws were in accordance with the requirements of domestic agriculture bureaucracies and of broader agricultural interests, as Bernstein and Cashore (2012) suggest.

The World Bank, as an international bureaucracy, has assisted more than 50 developing countries in the development of their environmental, legal, and institutional capacities (Marschinski and Behrle 2009). The direct access pathway is not the only source of the World Bank's influence; there is also the fact that engagement by the World Bank provides credibility to foreign investors (Marschinski and Behrle 2009). In Argentina, international investments in the forestry sector reached US $\$ 2.9$ billion in the period 1992-2013. Similar funding to that provided by the World Bank, but from a different actor, would probably not have resulted in the same degree of direct access. Further studies should focus on the relationship between the direct access pathway and the power of the actor using this

${ }^{5}$ http://www.worldbank.org/ar. 
pathway. This is because such actor-specific power functions as leverage for any means of direct access (e.g., capacity building, funding). This leads to the assumption that the same magnitude of direct access can cause quite different changes in domestic policymaking due to information means, trust and reputation, additional potential funds, other (dis-)incentives, or even coercive actions.

The invitation made by a domestic actor is of great importance in the process of direct access. Previous studies have shown that domestic actors and their networks can influence intergovernmental negotiations to secure international norms that support their interests (Gale and Cadman 2014). In Argentina, the agricultural sector is a strong policy sector composed of several associations (e.g., SRA, CRA) that supported the neoliberal discourse initiated in 1991 (Leon and Rossi 2003). Agricultural landowners, together with the forestry sector, supported all neoliberal measures, as well as the incentive policies encouraging plantation forests. The dismantling of IFONA, which led to the separation of native and plantation forests, including plantation forests in the Secretariat of Agriculture, is in line with the empowerment of the agriculture sector. Although the Directorate for Native Forests was able to increase its power due to its coalition with the World Bank, it still represents a reduction in scale, from an autonomous forest bureaucracy to one unit within a secretariat of environment.

Neoliberalism is one of the most influential discourses of our time, and gained strength as a normative discourse in the 1980s after the United States and United Kingdom adopted neoliberal policies (Humphreys 2009). The World Bank and the International Monetary Fund have promoted neoliberal ideas like trade liberalization, privatization, and deregulation in developing countries (Humphreys 2009). In the 1990s the new neoliberal discourse in Argentina paved the way for a coalition of agricultural interests, together with the World Bank, to influence forest policy and administration structure, through direct access. This result suggests that the pathway of international norms and discourse proposed by Bernstein and Cashore (2012), rather than a stand-alone pathway, may be interpreted as a pre-stage preparing the way for the other pathways to appear. In our results, the discourse pathway prepared the way for the direct access pathway. Future studies should focus on the interlinkages of the different pathways, especially on the relationship of the discourse pathway with the other three pathways of influence (Arts and Babili 2012; Krott and Giessen 2014).

\section{Acknowledgments}

The authors thank the anonymous referees for their helpful comments on the article.

\section{Funding}

This research was supported by funding from the Eva Mayr-Stihl Foundation, the German Research Foundation (DFG PAK 813), and Erasmus Mundus Action 2 EUROPLATA partnerships.

\section{References}

Arts, B., and I. Babili. 2012. Global forest governance: Multiple practices of policy performance. In Forest and nature governance, ed. B. Arts, J. Behagel, S. van Bommel, J. Koning, and E. Turnhout 111-32. Amsterdam, the Netherlands: Springer.

Bernstein, S., and B. Cashore. 2000. Globalization, four paths of internationalization and domestic policy change: The case of ecoforestry in British Columbia, Canada. Canadian Journal of Political Science/Revue Canadienne De Science Politique 33:67-99. doi:10.1017/s0008423900000044 
Bernstein, S., and B. Cashore. 2012. Complex global governance and domestic policies: Four pathways of influence. International Affairs 88:585-604. doi:10.1111/j.1468-2346.2012.01090.x

Biermann, F., B. Siebenhüner, S. Bauer, P. Busch, S. Campe, K. Dingwerth, T. Grothmann, R. Marschinski, and M. Taradell. 2009. Studying the influence of international bureaucracies. A conceptual framework. In Managers of global change: The influence of international environmental bureaucracies, ed. F. Biermann and B. Siebenhüner, 37-74. Cambridge, MA: MIT Press.

Burns, S. L., and L. Giessen. 2014. Identifying the main actors and their positions on international forest policy issues in Argentina. Bosque (Valdivia) 35:163-73. doi:10.4067/s071792002014000200004

Carranza, M. E. 2005. Poster child or victim of imperialist globalization? Explaining Argentina's December 2001 political crisis and economic collapse. Latin American Perspectives 32:65-89. doi:10.1177/0094582X05281114

Denegri, G., and M. Aguerre. 1996. Incidencia de las políticas de sustitución de importaciones de madera sobre las forestaciones, en el período 1960/94" [Incidence of the wood substitution import policies over forest plantation, in the period 1960/64]. Revista Realidad Económica 141:104-13.

Gale, F., and T. Cadman. 2014. Whose norms prevail? Policy networks, international organizations and "sustainable forest management." Society and Natural Resources 27:170-84. doi:10.1080/ 08941920.2013.840875

Gartland, H. M. 2012. Política y legislación forestales [Forest policy and legislation]. Buenos Aires, Argentina: Hemisferio Sur.

Gautier, D., T. A. Benjaminsen, L. Gazull, and M. Antona. 2013. Neoliberal forest reform in Mali: Adverse effects of a World Bank "success." Society and Natural Resources 26:702-16. doi:10.1080/08941920.2012.709587

George, A. L., and A. Bennett. 2005. Case studies and theory development in the social sciences. Cambridge, MA and London, England: MIT Press.

Giessen, L. 2013. Reviewing the main characteristics of the international forest regime complex and partial explanations for its fragmentation. International Forestry Review 15:60-70. doi:10.1505/ 146554813805927192

Giessen, L., M. Krott, and T. Möllmann. 2014. Increasing representation of states by utilitarian as compared to environmental bureaucracies in international forest and forest-environmental policy negotiations. Forest Policy and Economics 38:97-104. doi:10.1016/j.forpol.2013.08.008

Gulbrandsen, L. 2003. The evolving forest regime and domestic actors: Strategic or normative adaptation? Environmental Politics 12:95-114. doi:10.1080/09644010412331308204

Hogl, K., R. Nordbeck, and E. Kvarda. 2009. When international impulses hit home: The role of domestic policy subsystem configurations in explaining different types of sustainability strategies. Forest Policy and Economics 11:357-64. doi:10.1016/j.forpol.2008.07.003

Humphreys, D. 2006. Logjam-Deforestation and the crisis of global governance. London, UK: Earthscan.

Humphreys, D. 2009. Discourse as ideology: Neoliberalism and the limits of international forest policy. Forest Policy and Economics 11:319-25. doi:10.1016/j.forpol.2008.08.008

Karsenty, A., and S. Ongolo. 2012. Can "fragile states" decide to reduce their deforestation? The inappropriate use of the theory of incentives with respect to the REDD mechanism. Forest Policy and Economics 18:38-45. doi:10.1016/j.forpol.2011.05.006

Koontz, T. M., and J. Newig. 2014. From planning to implementation: Top-down and bottom-up approaches for collaborative watershed management. Policy Studies Journal 42:416-42. doi:10.1111/psj.12067

Krasner, S. D. 1982. Structural causes and regime consequences: Regimes as intervening variables. International Organization 36:185-205. doi:10.1017/s0020818300018920

Krott, M., A. Bader, C. Schusser, R. R. Devkota, A. Maryudi, L. Giessen, and H. Aurenhammer. 2014. Actor-centred power: The driving force in decentralised community based forest governance. Forest Policy and Economics 49:34-42. doi:10.1016/j.forpol.2013.04.012

Krott, M., and L. Giessen. 2014. Learning from practices-Implications of the "practice based approach" for forest and environmental policy research. Forest Policy and Economics 49:12-16. doi:10.1016/j.forpol.2013.04.013 
Leguizamón, A. 2013. Modifying Argentina: GM soy and socio-environmental change. Geoforum 53:149-60. doi:10.1016/j.geoforum.2013.04.001

Leon, C. A., and C. A. Rossi. 2003. Aportes para la historia de las instituciones agrarias de la Argentina (I). La Junta Nacional de Granos [Contribution to the history of agrarian institutions in Argentina (I). The national board of grains]. Realidad Economica 196:84-101.

Marschinski, R., and S. Behrle. 2009. The World Bank: Making the business case for the environment. In Managers of global change: The influence of international environmental bureaucracies, ed. F. Biermann and B. Siebenhüner 101-42. Cambridge, MA: MIT Press.

McDermott, C. L., B. Cashore, and P. Kanowski. 2010. Global environmental forest policies: An international comparison. London, UK: Earthscan.

Neuman, W. L. 2005. Social research methods. Quantitative and qualitative approaches. London, UK: Allyn and Bacon.

Pengue, W. A. 2005. Transgenic crops in Argentina: The ecological and social debt. Bulletin of Science, Technology and Society 25:314-22. doi:10.1177/0270467605277290

Peters, B. G. 2010. The politics of bureaucracy-An introduction to comparative public administration. Oxon, UK: Routledge.

Rayner, J., M. Howlett, J. Wilson, B. Cashore, and G. Hoberg. 2001. Privileging the sub-sector: Critical sub-sectors and sectoral relationships in forest policy-making. Forest Policy and Economics 2:319-32. doi:10.1016/s1389-9341(01)00038-7

Romero, J. E. 2012. Forest conservation in Argentina: Early analysis of the forest law implementation in the Chaco ecoregion. Master of science thesis, UBC, Vancouver, BC, Canada.

Secretaría de ambiente y desarrollo sustentable Argentina. 2005. Primer inventario nacional de bosques nativos. [First national native forests inventory]. BIRF 4085-AR 1998-2005. Secretaría de Ambiente y Desarrollo Sustentable, Ciudad Autonoma de Buenos Aires, Argentina.

Silva, H. T., P. De Paepe, W. Soors, O. V. Lanza, M. C. Closon, P. Van Dessel, and J. P. Unger. 2011. Revisiting health policy and the World Bank in Bolivia. Global Social Policy 11:22-44. doi:10.1177/ 1468018110391999

Teubal, M. 2011. La crisis de 2001-2002 y el colapso del neoliberalismo en la Argentina [The 2001-2002 crisis and the collapse of neoliberalism in Argentina]. Realidad Economica 261:58-84.

Tuozzo, M. F. 2004. World Bank, governance reforms and democracy in Argentina. Bulletin of Latin American Research 23:100-18. doi:10.1111/j.1470-9856.2004.00098.x

Tuozzo, M. F. 2009. World Bank influence and institutional reform in Argentina. Development and Change 40:467-85. doi:10.1111/j.1467-7660.2009.01559.x

World Bank. 1991. The forest sector: A World Bank policy paper. Washington, DC: The World Bank. http://documents.worldbank.org/curated/en/1991/09/440705/forest-sector (accessed April 7, 2014).

World Bank. 1995. Staff appraisal report Argentina forestry development project. http://documents. worldbank.org/curated/en/1995/09/697030/argentina-forestry-development-project (accessed December 3, 2013).

World Bank. 1996. Staff appraisal report Argentina native forests and protected areas project. http:// documents.worldbank.org/curated/en/1996/08/696301/argentina-native-forests-protected-areasproject (accessed December 3, 2013).

World Bank. 2006. WB implementation completion report forestry development project. http:// documents.worldbank.org/curated/en/2006/07/6980620/argentina-forestry-development-project (accessed January 9, 2014).

World Bank. 2007. WB implementation completion and results report Argentina native forests and protected areas project. http://documents.worldbank.org/curated/en/2007/12/9402795/argentinanative-forests-protected-areas-project (accessed December 2, 2013).

World Bank. 2008. WB project appraisal document on sustainable natural resources management project report. http://documents.worldbank.org/curated/en/2008/01/9047518/argentina-sustainable-natural-resources-management-project (accessed December 6, 2013).

World Bank. 2011. WB project performance assessment report Argentina native forests and protected areas project and biodiversity conservation project. http://documents.worldbank. org/curated/en/2011/06/14499107/argentina-native-forests-protected-areas-project-argentinabiodiversity-conservation-project (accessed December 2, 2013). 



\title{
State actors and international forest certification policy: Coalitions behind FSC and PEFC in federal Argentina
}

\author{
Sarah L. Burns ${ }^{a, b, *}$, Pablo F. Yapura ${ }^{\mathrm{b}}$, Lukas Giessen $^{\mathrm{a}}$ \\ a University of Göttingen, Chair of Forest and Nature Conservation Policy, Germany \\ b Universidad Nacional de La Plata, Facultad de Ciencias Agrarias y Forestales, Laboratorio de Investigación de Sistemas Ecológicos y Ambientales, La Plata, \\ Argentina
}

\section{A R T I C L E I N F O}

\section{Article history:}

Received 7 April 2015

Received in revised form 9 October 2015

Accepted 8 December 2015

\section{Keywords:}

Bureaucratic politics

International forest regime

Transnational regimes

Coalitions

Federalism

Private actors

\begin{abstract}
A B S T R A C T
Forest certification has been so far described as a non-state, market-driven form of private governance developed by non-state actors. However, bureaucracies can influence the effects of these programs in many ways, using their competencies to either enhance or restrict non-state certification schemes. The objective of our work is to analyze the role state agencies played in the forest certification standard development processes in Argentina, including the related coalition building strategies. Our hypotheses are that forest certification is not an activity among merely private actors, but that state agencies do play a small but necessary role in creating favorable frame conditions, and in standard formulation and scheme establishment. Coalitions built around production-oriented state agencies and strong political sectors have a stronger influence in the formulation of standards of forest certification schemes than coalitions between conservation-oriented bureaucracies and environmental NGOs. In order to understand the process of standard formulation for FSC and PEFC in Argentina, data on the different schemes were collected from public statements from stakeholder organizations, written summaries of debates of schemes from both public meetings and meetings by the groups writing the standards, and statements from the agencies in charge of writing the standards. The results show that in Argentina, FSC was temporarily useful to the forestry sector and landowners as a quick solution and hence was supported even by utilitarian state agencies. In light of an evolving operational PEFC scheme four years later, this support by state agencies was dropped and shifted towards the more landowner-friendly PEFC. After this dynamic in the coalition building process, FSC was on a decline in Argentina.
\end{abstract}

(c) 2015 Elsevier Ltd. All rights reserved.

\section{Introduction}

After the failed intergovernmental efforts to agree on a legally binding convention on forests at the Rio Summit in 1992, environmental nongovernmental organizations, led by the World Wildlife Fund (WWF) in coalition with other non-state actors, founded the Forest Stewardship Council (FSC) in 1993 as an instrument to promote sustainable forest management through certification (Tosun, 2012). As a response to this initiative, forest-based industries and private landowner associations, in coalition with productionoriented bureaucracies in many producer countries, created a more "industry-friendly" competitor scheme for forest certification. They eventually joined in a common organization founded in 1998,

\footnotetext{
* Corresponding author at: Chair of Forest and Nature Conservation Policy, University of Göttingen, Büsgenweg 3, Göttingen 37077, Germany.

E-mail addresses: sarah.burns@forst.uni-goettingen.de, salibu@agro.unlp.edu.ar (S.L. Burns).
}

which later became the Programme for the Endorsement of Forest Certification (PEFC) (Dietrich and Tosun, 2013; Gulbrandsen, 2014). In the case of Argentina, FSC was established in 2001, supported even by private landowners, but has been followed by a recent initiative to transition to PEFC.

With this increased participation of non-state actors, through forest certification a new form of political steering has been promoted based on voluntary agreements. In the political science body of literature, forest certification has been so far described as a non-state, market-driven form of private governance developed by non-state actors and building on private institutions (Cashore et al., 2005; Pattberg, 2007). In international policy, it is currently referred to as transnational regimes (Pattberg, 2012) and more broadly discussed under the concept of forest governance (Agrawal et al., 2008; Art, 2014; Giessen and Buttoud, 2014).

These perspectives in political science highlight aspects relating to the role of private actors and private institutions and the way they gain authority vis-à-vis state failure to solve forest 
problems, and they are accompanied by a perceived decline in power of forest related public actors and institutions (Ho, 2006: Wibowo and Giessen, 2015). This view, however, leaves largely underrepresented the role of the state in e.g., creating, enabling, or obstructing conditions for forest certification in general and individual certification schemes in particular. It further downplays the role of the multiple and often competing state bureaucracies in certification politics, which may be crucial as both resources of power and as coalition partners in the establishment process of a particular scheme vis-à-vis their competitors.

This important role of specific state actors is reflected in theoretical innovations, leading away from forest governance but pointing towards a forest governmentality approach for political certification studies (Art, 2014). Recent empirical findings support this governmentality perspective and even suggest a crucial role for state agencies in forest certification and related politics (Cashore et al., 2004; Gale and Haward, 2011; Bartley, 2014; Gulbrandsen, 2014). According to this literature, state agencies can obstruct (Gulbrandsen, 2010, 2014; Gale and Haward, 2011; Sahide et al. 2015b) or support certification initiatives (Hysing, 2009; Bell and Hindmoor, 2012).

The aim of this study is to analyze against this background the so far under-researched role state agencies played in the consecutive FSC and PEFC standard development processes in Argentina, including the related coalition building strategies.

\section{Theoretical propositions}

Since the Rio Summit in 1992, a growing number of international regimes addressing forests have evolved into what can be described as an international forest regime complex (Humphreys, 2006; Giessen, 2013). An international regime can be defined as "a set of implicit or explicit principles, norms, rules and procedures around which actorsí expectations converge in a given area of international relations" (Krasner, 1982). These regimes attempt to influence domestic policies at national levels. At the same time, with the increased participation of non-state actors, a new form of governance based on voluntary agreements was created. This new form of private governance has been referred to as transnational regimes. The main difference between international and transnational regimes is that in the latter, non-state actors generate the set of norms and rules instead of states (Pattberg, 2012).

For both international and transnational regimes to become relevant at the national level there has to be a local actor advocating for it and forming favorable conditions. Domestic actors may take advantage of new international norms and policy discourses in order to break into or re-shape domestic actor networks (Hogl et al., 2009; Sahide et al., 2015a). Previous studies have shown that international regimes may lead to changes in the relation of power within domestic networks, strengthening certain groups of actors while weakening others (Grugel and Peruzzotti, 2010; Burns and Giessen, 2015). Transnational regimes might have the same impact at the national level with domestic actors seeking coalitions with international actors in their pursuit for favorable policies. In this pursuit private actors may act individually (e.g., lobbying, personal contacts) but also collectively (e.g., through coordinated actions by their associations or by forming coalitions) (Tosun, 2013). In the case of coalitions with state bureaucracies this is referred to as corporatism, defined as "a mutually beneficial exchange between interest groups and government where some actors control something that others desire" (Öberg et al., 2011, 365). In this exchange state bureaucracies seek more responsibility in policy domain while controlling public expenditure and legislative power (Peters, 2010) and private actors seek to influence public policy that is favorable to them while at the same time providing consent, approval or active support of certain bureaucracies and their policies (Öberg et al., 2011). In federal countries, like Argentina, with strong subnational institutions, stratification into provinces provides multiple coalition options for both national as well as actors from transnational regimes expanding the arenas of contestation. This exchange between private and public actors is necessary even in private governance where state bureaucracies are claimed to play a small but necessary role (Hysing, 2009; Gulbrandsen, 2010, 2014; Gale and Haward, 2011).

According to the bureaucratic politics theory, those national and subnational state bureaucracies being involved in such multilevel politics, compete with each other for resources, staff, and the responsibility for policy domains (Krott, 2005; Peters, 2010; Giessen et al., 2014). In order to increase their power, national and subnational bureaucracies are likely to seek coalition with other national and international actors (both public and private) having compatible interests, making up a policy sector (Rayner et al., 2001; Giessen and Krott, 2009). Policy sectors "focus on a specific area of public policy (forests, water, agriculture, etc.) and include all the groups, organizations, and institutional rules pertaining to that arena of policy making and implementation" (Shannon and Schmidt, 2002). In joining forces of their actors in a corporatist fashion, policy sectors attempt to influence public policy as coalitions. These coalitions can be of two types: (a) stable over time forming policy sectors; (b) ad hoc when new promising venues for political influence open (Rommetvedt et al., 2012).

Domestic bureaucracies may use international issues to strengthen their positions vis-à-vis competing agencies, both at the national as well as the provincial level, by taking up issues, discourses and norms to legitimize their roles as well as by finding domestic or international coalition partners (Bernstein and Cashore, 2012; Giessen, 2013; Wibowo and Giessen, 2015). In federal countries, international issues shift the power balance towards national bureaucracies, even in issues that are actually within the provincial domain (Hofmann, 2002; Scharpf, 2006). As a response to this shift in power balance, subnational bureaucracies try to get involved in international issues as well. How they will pursue this depends on how responsibilities regarding a certain issue are vertically distributed between the national and subnational governments (Lopreite, 2014) but national bureaucracies will remain in a better position. In cases where subnational bureaucracies have the competency over certain issues they might be stronger than in issues of national competences (Lopreite, 2014).

Both international and transnational regimes operate in a wide range of issue areas (Pattberg, 2012). Forest certification has been described as a transnational regime where non-state actors, by means of markets, establish international institutions made of norms and rules (Cashore, 2002; Pattberg, 2007; Bernstein and Cashore, 2012). Although forest certification schemes are considered as internationally formulated, the national level plays an important role in the formulation of national standards and their implementation (Keskitalo et al., 2009). FSC has one set of principles and criteria defined by FSC-International; however, the actual standards and criteria are defined by regional working groups coordinated by national chapters (Espach, 2006). PEFC, on the other hand, is based on the standards developed by each nation, which are then evaluated by PEFC International under certain minimum requirements (Tosun, 2012; Gulbrandsen, 2014). This process led to the development of two different coalitions, one advocating for conservation practices and the other with production-oriented interests.

Against this theoretical background of national and subnational level public bureaucracies trying to increase their influence over private governance initiatives, we formulate the following propositions: 
1. Forest certification and state actors: Although it is often claimed that transnational regimes are an activity among merely private actors, state bureaucracies do play a small but decisive role. In forest certification, state bureaucracies play an important role as coalition partners bringing resources, in both FSC and PEFC.

2. Coalitions and weak bureaucracies:

a. Competing national bureaucracies seek coalitions with domestic as well as international actors to enhance their power vis-à-vis other bureaucracies and private actors. In the case of forest certification national bureaucracies seek coalitions with international actors as the EU, WB, FSC international and PEFC international to enhance their power in the standard development of specific forest certification schemes, which private conservation and production-oriented actors try to obstruct.

3. Domestic private actors form stable coalitions with state bureaucracies building up a policy sector. However, in cases of new venues for political influence they would prefer ad hoc coalitions. In the case of establishing certification schemes, private production-oriented actors, such as private landowners, prefer employing rather weak bureaucracies that are (i) not permanently in charge of standard development and (ii) less knowledgeable about technological details of forest certification.

- Federalism: Despite provinces being strong actors in forest issues, national bureaucracies gain relative power due to international influences as forest certification processes.

\section{Methods}

\subsection{Case description}

In Argentina, there are around 31.4 million hectares of natural forests divided into six ecological regions (SAyDS, 2005). Moreover, there are 1.2 million hectares of cultivated forests, $80 \%$ of which are located in the northeast of the country, in the Mesopotamian region (MAGyP, 2013). Argentina adopted a federal republican representative form of government. Except for national parks, which are under the jurisdiction of the national government, forests toile within the political responsibility of the provinces and are subject to provincial laws under the umbrella of national laws (Article 124 of the National Constitution 1994). At a national level, the Secretariat of Environment and Sustainable Development is responsible for natural forests, while the Ministry of Agriculture, Livestock and Fisheries is responsible for forest plantations. Forests are mainly owned privately: $99.7 \%$ of plantation forests and $93.5 \%$ of natural forests are privately owned (Burns and Giessen, 2014). Hence, this provides an interesting case to analyze coalition options between strong private actors as landowners and national and subnational state bureaucracies.

In the early 1990s, in the middle of an economic crisis, a strong coalition of (agricultural and profit-oriented) bureaucracies and associations of private landowners (in forestry as well as agriculture) emerged, advocating for more profitable and productive land uses with subsequent supporting policies and administrative frameworks (Burns and Giessen, 2015). At this time, international actors as the FAO and the World Bank played a crucial role supporting the domestic coalition of pro-agriculture public and private actors. As a consequence, the Argentine National Forestry Institute (IFONA), a strong and comprehensive forest bureaucracy, was dismantled into four weaker bureaucracies (Burns and Giessen, 2015). By forming coalitions with the World Bank, some of the newly created bureaucracies were able to increase their power (Burns and Giessen, 2015). The administrative reform and policy changes carried out with funding and a high level of political support provided by the World Bank led to increased investments in the forestry sector, mainly by international firms, especially from Chile (between 1992 and 2013, 66\% of the total investments in the forestry sector was done by Chilean companies with three Chilean forestry firms dominating Argentinaís forest holdings and wood exports) (Espach, 2005; Burns and Giessen, 2015). Thus, being a good case to analyze coalition building between domestic and international actors.

As part of the political changes taking place in the beginning of the 1990s the National Constitution was reformed in 1994. With this reform, provinceís sovereignty over their natural resources was stated clearly giving the provinces the right to legislate on forest issues within their territory. This makes the subnational bureaucracies involved in the forest sector important actors and potential coalition partners. However, with the new government that took over after the 2001 crisis, the national government increased their power vis-à-vis the provinces by means of new sources of revenue that were not shared between the federal and provincial governments, decreasing provincesí share of overall revenue and increasing provincial governmentsí dependence on the federal government (Levitsky and Murillo, 2008). This case of strong federalism with strong links between the national and provincial level provides a good case to analyze the role of national and subnational level as coalition partners in the development of forest certification schemes.

Between 2001 and 2002, Argentina began the development of forest certification processes, both FSC and PEFC. These processes continued until the year 2014 with the development of standards, providing an appropriate case for studying the role of different state actors, both national and subnational, and the coalitions made, in the development of forest certification schemes.

\subsection{Empirical methods}

In order to analyze the role of different state and private actors and their coalitions in the development of forest certification schemes, we used a qualitative case study approach employing process tracing (George and Bennett, 2005), which "attempts to trace the links between possible causes and observed outcomes" (George and Bennett, 2005, 6), focusing on sequential processes within a particular case. By providing theory-based historical explanations for a case in which each significant step toward the outcome is explained by referring to a theory, process tracing becomes a powerful method of inference (George and Bennett, 2005, 30). Data from different sources were collected with the aim of determining the role of state bureaucracies in the development of two competing forest certification schemes, FSC and PEFC. As a first step, a literature search was done from professional journals and websites of certification bodies, environmental NGOs, forestry associations, and related bureaucracies, in order to gather data on the certification process and identify key actors. Subsequently, semi-structured interviews were conducted with experts having broad knowledge of private and state certification processes. Interviews lasted between half an hour and two hours. If it was not possible to meet with the interviewees in person, they were contacted by phone calls or emails. In all cases, interviewees were granted confidentiality in order to ensure full disclosure (Koontz and Newig, 2014). In total, five interviews were conducted between October 2013 and August 2014. Data was used for the triangulation between documentary sources and all of the interviews, ensuring its validity and reliability (Koontz and Newig, 2014; Lorenzoni and Benson, 2014). If there were contradictions or differences in interpretation, priority was given to written records (Davies, 2001). Qualitative content analysis was used to analyze all documents and interviews (Neuman, 2005) for revealing the role of state agencies in the institution and the setup and operation of certification schemes and standards. 


\section{Results}

\subsection{FSC as an interim solution for landowners}

FSC was first put on the political agenda in 2001 by the Secretariat of Agriculture by organizing a workshop about a potential FSC in Argentina (FVSA, 2003, Interview 1). However, FSC first arrived in the country at the beginning of 2001, when an international oil company certified their plantation forests in the northeast of Argentina (Sanchez Bonifato, 2001).

By the end of 2001, the Argentinian partner of WWF, Fundación Vida Silvestre Argentina (FVSA), housed FSC in the country by providing office spaces (FVSA, 2003). At the beginning of 2002, different meetings and workshops were held that aimed at creating a working group responsible for drafting national plantation forest management standards. At this time, FSC International recognized the General Director of the FVSA as the contact person of FSC Argentina, the first step in the development of the national initiative (FSC, 2002). By June 2002, a National Working Group was created in a meeting held at the Secretariat of Environment and Sustainable Development (FVSA, 2002). This group had three chambers (social, environmental, and economic) with five members each; half of the members represented both environmental and social NGOs, $25 \%$ represented the forest companies, and the other 25\% represented different bureaucracies (FVSA, 2003). This group was elected mainly for drafting the national standards for the management of plantation forests with the aim of getting FSC endorsement. Both, the Secretariat of Environment and Sustainable Development and the Secretariat of Agriculture, Livestock, and Fisheries participated in the development of the FSC national standards for plantation forests by being part of the environmental chamber (FVSA, 2003). The biggest transnational forest companies in Argentina, who operate large-scale and rapidly growing plantations for the production of pulp and sawn wood, participated in the development of standards in the economic chamber (FVSA, 2003), although so far none of them has sought certification. However, most of these companies cannot certify under FSC, due to FSC's prohibition of certification for any plantation established after 1994 on land that was previously native forest (Espach, 2006). This regulation is part of FSC's international set of Principles and Criteria and could not have been modified by the national chapter.

At the same time that the National Working Group was created, a Regional Working Group was appointed for developing forest management standards for the Atlantic Forest eco-region (FVSA, 2003). After the elective process of the Regional Working Group, representation conflicts arose (FVSA, 2003). To overcome this situation, the entire National Initiative became greatly involved in the dispute resolution. After many meetings between National Initiative delegates and the local stakeholders involved, including the recently elected members of the Regional Working Group, the parties reached consensus about initiating standard drafting for the natural forest of the eco-region, committing themselves to undergoing a revision of the representatives' election process within a six-month term (FVSA, 2003). However, this never actually happened, even though a consultant was hired for this purpose (FVSA, 2003). This situation reflects the strong opposition FSC certification faced in that part of the country, mainly from big Chilean companies that are the main investors in fast-growing species plantations in the area (Espach, 2006).

Both the national and regional initiatives were funded by WWF Switzerland and WWF International through their program Forest for Life (FVSA, 2003). A few months after the election of the Atlantic forest Regional Working Group, in coalition with two other environmental NGOs (Greenpeace and Proyungas) and with funding until the year 2006 from a private company in the oil and gas sector (Gasoducto Nor Andino Argentina SA), several meetings were held to launch the regional initiative of the Yungas ecoregion (FVSA, 2003). However, both efforts and funding for these three initiatives were insufficient for achieving the stated goals (Interview 1). Two other Ecoregional initiatives were proposed (Chaco and Bosques Andino-patagonicos), but without funding (FVSA, 2003).

The National Working Group divided the writing of the standards between the three chambers, assigning specific principles and criteria to each of them. Each chamber took a different approach, including the designation of a writing committee (Environmental Chamber), working in plenary sessions (Economic Chamber), and organizing workshops for stakeholders' input (Social Chamber) (FVSA, 2003). Both the economic and environmental chambers made progress throughout 2003; however, the social chamber made almost no progress at all. As a result, the National Working Group requested the National Initiative Coordinator to compile, edit, and complete the standard draft. This meant compiling all of the work done by the chambers, and completing the issues not covered by any of the chambers (FVSA, 2003). In 2005, the National Initiative of FSC began public consultation on the first draft of the standards for sustainable forest management of forest plantations (Cerfoar, 2013a). However, this standard was never approved. After the consultation, negotiations over starting a pilot test began, but this also was not accomplished (Interview 1). After the failure of this initiative, FSC ceased to have a national focal point in Argentina, and FVSA ceased to be a member of FSC (FSC, 2014). However, in 2010, a new civil society with members from forestry associations and environmental NGOs was formed with the aim of drafting national standards according to the new set of principles and criteria of the FSC (Interviews 2 and 3), and it has been the national focal point in Argentina since the end of 2014.

\subsection{PEFC as a subsequent attempt to replace the ambitious FSC scheme}

In the year 2002, PEFC, originally conceived as a European system, started admitting non-European members (Cerfoar, 2013a). At this time, the national organism responsible for writing all norms in Argentina, along with the ISO national body, IRAM, began developing the technical norms of voluntary application meant to be the basis of the national system of forest certification (Cerfoar, 2013a).

In 2004, in union with Brazil, Chile, and Uruguay, IRAM signed a regional technical co-operation treaty, with funding from the World Bank, called "Market access and integration through technical standardization" (Cerfoar, 2013a). At the same time, the Secretariat of Agriculture began negotiations with the European Union to obtain funding for the creation of a National Program for the Certification of Forest Plantations. This project established the National Institute of Agricultural Technology (INTA), an autarchic organism dependent on the Secretariat of Agriculture, in charge of writing the standards of sustainable forest management for forest plantations (Escobar, 2006, Interview 3 and 5). In the beginning, both bureaucracies worked together in the writing for this project; however, after the first meetings, the Secretariat of Agriculture presented the project on its own (Cerfoar, 2013a). This project was approved by the European Union at the end of 2004. Both bureaucracies competed for responsibility in policy domain, aiming to be in charge of the development of national standards. By seeking coalitions with international organizations like the World Bank and the European Union, both bureaucracies increased their power, by means of funding, in the role on standard development. Moreover, IRAM had support from the private sector through the main three forest associations (Argentine Forest Association-AFoA, the Argentina Federation of Wood and Allied Industries-FAIMA, and the Cellulose and Paper Manufacturers Association-AFCP), who provided this initiative with office spaces. 
At the end of 2005, IRAM began to raise the topic of gaining recognition by PEFC, pointing out the need to include public bureaucracies and the private sector in the process. At that time, both bureaucracies (IRAM and INTA) were developing projects of similar conditions, developing a technical norm of voluntary application. IRAM stated the intention of establishing a dialogue in order to join forces (Cerfoar, 2013a). By the middle of 2006, members of the project run by the Secretariat of Agriculture with funding from the EU started joining the meetings organized by IRAM, having made the decision to work together (Cerfoar, 2013a). At that time, the Direction of Forestry from the Secretariat of Agriculture became an official member in the writing of the standards with voice and vote privileges (Cerfoar, 2013a). However, IRAM is the national organization in charge of writing national norms, so INTA's intention to write the norms themselves was not possible, and after some time co-operation stopped. In 2007, the EU dropped funding to the Secretariat of Agriculture and the project was cancelled (Argentina Forestal, 2007). With the project finished, representatives of the Secretariat of Agriculture resigned their positions in the working group responsible for writing the norms. Until this point, it had been decided that the Secretariat of Agriculture was going to be responsible for starting the process of mutual recognition with PEFC (Cerfoar, 2013a). As a solution to the lack of a bureaucracy taking the lead in getting mutual recognition with PEFC, CERFOAR, a civil non-profit association, was formed in 2009 by the three forestry associations (AFoA, FAIMA, and AFCP) to manage the Argentine Forest Certification System. A year later, during the 14th PEFC General Assembly in Rio de Janeiro, Brazil, CERFOAR was accepted as a PEFC National Governing Body (PEFC, 2013). This situation favored the forest associations, who became founding members of the national governing body with full administrative power and the ability to invite any actor of their preference to become member of this body. Once the association was established, they invited different national bureaucracies and their technical institutes to be part of the development and implementation of the national certification system and take part in the decisions by joining the association administering CERFOAR (Cerfoar, 2013b). During the beginning of 2010, the secretary of CERFOAR met with the Director of Forestry from the now Ministry of Agriculture, Livestock, and Fisheries. During this meeting, they talked about the role the Ministry of Agriculture could play in financing the endorsement of CERFOAR with PEFC and worked on defining the commitments, and it was established that the Ministry of Agriculture's legal advisors would study a model of agreement with the association administering CERFOAR (Cerfoar, 2013a). The Secretariat of Environment never replied to the invitation to be part of the association that administers CERFOAR (Interview 2). Nowadays, the following entities are part of the CERFOAR Association: AFoA, FAIMA, and AFCP (as founding members), the National Industry Secretariat, National Institute of Agricultural Technology, National Ministry of Agriculture, Livestock, and Fisheries, Ministry of Ecology and Natural Resources of the Province of Misiones, and the Ministry of Work, Production and Tourism of the Province of Corrientes (Cerfoar, 2013c, Interview 5). In 2014, CERFOAR acquired the mutual recognition of PEFC.

The process of developing standards for sustainable forest management began in 2003 and ended in 2010 with the approval of the standards following widespread national public consultation and three pilot tests (Cerfoar, 2013b). The technical norms meant to be the basis of the national system of forest certification were developed through a Standard Setting Forum coordinated by IRAM in the presence of technical advisors from different organizations (Cerfoar, 2013a). Throughout the process, 97 different experts participated, $35 \%$ representing the forestry associations, $21 \%$ the Secretariat of Environment, 17\% the Secretariat of Agriculture, and
$21 \%$ representing other national and provincial bureaucracies. Only $3 \%$ represented environmental NGOs (Cerfoar, 2013d).

\section{Discussion and conclusion}

\subsection{Forest certification and specific state bureaucracies}

Forest certification started as a transnational regime, with the conservation-oriented private sector as the main driver. By means of the national implementation of the schemes, with the active presence of national conservation-oriented actors and little participation from national bureaucracies, these transnational regimes became influential at the national level. This can be seen in the case of FSC in Argentina, where a national environmental NGO housed FSC and acted as coordinator of the development of the standards. However, despite what is often claimed (Cashore, 2002; Pattberg, 2005; Auld et al., 2008), state bureaucracies play a decisive and active role in forest certification processes. Forest certification through FSC was first put into the political agenda by the Secretariat of Agriculture through organizing a workshop about the potential implementation of FSC in the country. This is in line with our proposition that bureaucracies can support certification schemes by informational means. During the development of FSC national standards, both, the Secretariat of Environment and Sustainable Development and Secretariat of Agriculture, Livestock, and Fisheries participated as members of the environmental chamber. This shows that national forest bureaucracies supported FSC in Argentina, at least in the beginning, through both informational instruments and the provision of staff. By involvement in the negotiation of standards, national bureaucracies could try to influence the final standards according to their interests. However, national standards for FSC were never achieved, showing the great competition faced by this system. Faggi et al. (2014) found that the main motivation for forest companies to achieve FSC certification was legal.

As a response to the development of a conservation-oriented forest certification scheme of high standards like FSC, productionoriented private sectors created more industry-friendly systems that could compete with, and later even replace conservationoriented systems. By forming coalitions with national state production-oriented bureaucracies, these competing schemes gained strength. In Argentina, the formulation of national standards for PEFC endorsement, an initiative carried out by the forestry associations in coalition with the Ministry of Agriculture and the National Standardization bureaucracy, presented strong competition to FSC. In this case, the Ministry of Agriculture, by becoming allies with the forestry associations through the provision of informational instruments and technical expertise in standard development, and later by incentive instruments, such as paying for the PEFC endorsement procedure, supported the creation of a more industry-friendly scheme that could compete with, and preferably even replace FSC in the country. A similar situation was observed in Indonesia, where the Ministry of Forestry supported forest certification by funding a national initiative (LEI) competing with FSC (Bartley, 2010; Wibowo et al. unpublished). One can argue that private landowners have more power in countries like Argentina and Indonesia with weak state capacities, however the same pattern was observed in countries with strong state capacity like Finland and Germany. In Finland, PEFC, with the support of forest owner organizations, out-competed FSC, with 95\% of the forests in the country certified under PEFC only one year after the approval of the standard (Keskitalo et al., 2009). In Germany, PEFC was created by the forest sector in coalition with other landowners and managers across Europe as a response to the ENGO driven FSC. In this 
case PEFC had a strong support from almost all private and state landowners (Cashore et al., 2003). As suggested by Öberg et al. (2011) corporatism does not depend on whether institutions are weak or strong but rather whether they are willing or not to engage in mutual exchanges.

\subsection{Coalitions with preferably weak bureaucracies}

Competing national bureaucracies seek coalitions with domestic as well as international actors (the EU, WB, FSC international, PEFC international) to enhance their power in standard development of forest certification schemes, which private conservation and production-oriented actors try to obstruct. In Argentina, environmental and social rights NGOs are mainly local in scope. The bigger national environmental NGOs like Greenpeace are more focused on urban problems, and although they are supporters of FSC, arguing that it is the only means of assuring environmental and social standards (Burns and Giessen, 2014), they do not consider forest management a priority (Espach, 2005). This situation makes coalitions between national NGOs difficult. Coalitions with international environmental NGOs like WWF allowed the development of the national initiative; however, these coalitions were not strong enough to overcome local resistance from the strong private sector, especially at the regional level.

By forming coalitions with national state production-oriented bureaucracies, competing schemes became strong. In Argentina, the formulation of national standards for PEFC endorsement, an initiative carried out by the forestry associations in coalition with the Ministry of Agriculture that emerged as strong competition for FSC, almost replaced it. In that case, the Ministry of Agriculture, by becoming allies with the forestry associations through the provision of informational instruments and technical expertise in standard development and later by incentive instruments, such as paying for the PEFC endorsement procedure, supported the creation of a more industry-friendly scheme that could compete with, and preferably even replace FSC in the country.

By seeking coalitions with international actors, the Ministry of Agriculture (formerly the Secretariat) and the National Standardization bureaucracy tried to enhance their power in the competition for policy domain on standard development of forest certification schemes. However, the forestry associations supported the National Standardization bureaucracy, which would not be permanently in charge, giving administrative power back to the landowners' sector. In the competition between these two bureaucracies, the Ministry of Agriculture could not achieve the policy domain of writing the national standards, and support from the EU was dropped. This supports our hypothesis that in situations where new promising venues for political influence open, private actors would prefer ad hoc coalitions with weaker bureaucracies that would not be permanent and with less technical knowledge.

\subsection{Forest certification and federalism}

International and transnational regimes can influence the national level, changing the power balance of the domestic networks. Domestic actors can use these regimes to shift the power balance in their favor. In federal countries, the political system provides multiple institutional access points for policy change. However, how important federalism is depends on how responsibilities regarding certain issues are vertically distributed between the national and the subnational governments (Lopreite, 2014). In cases where the issue at stake is within provincial competencies, the national level will try to use the international sphere to increase their responsibility (Scharpf, 2006; Wibowo and Giessen, 2015). This is the case with forests in Argentina, whose responsibility toils within the provincial level (Burns and Giessen, 2015). In the case of developing forest certification schemes national bureaucracies, like the Ministry of Agriculture, tried to increase their power over the provinces by leading the national initiative of an industryfriendly scheme like PEFC with the support of private landowners. In this case, despite the provinces retaining the power over forest issues, national bureaucracies by means of transnational regimes increased their power. The provincial bureaucracies, on the other hand, try to retain their power in forest issues but at the same time support their stable coalitions with private actors in their territories. In the case of forest certification in Argentina this was seen both in the development of FSC and PEFC. In the case of FSC, they tried to obstruct the development of regional standards, especially in the regions were forest landowners are stronger, like the Mesopotamia region. At the same time they joined the development of the PEFC standard, being part of the CERFOAR association. In cases where the jurisdiction over an issue lies at the national level, the subnational level can still use agenda setting and bills initiation to influence policy change (Lopreite, 2014).

\section{Acknowledgements}

This research was supported by funding from the Eva Mayr-Stihl Foundation, the German Research Foundation (DFG PAK 813), and Erasmus Mundus Action 2 EUROPLATA partnerships. The authors thank the anonymous referee for the very helpful and constructive comments on the article.

\section{References}

Auld, G., Gulbrandsen, L.H., McDermott, C.L., 2008. Certification schemes and the impacts on forests and forestry. Annu. Rev. Environ. Res. 33, 187-211.

Agrawal, A., Chhatre, A., Hardin, R., 2008. Changing governance of the world's forests. Science 320, 1460-1462.

Art, B., 2014. Assessing forest governance from a 'Triple G' perspective: government, governance, governmentality. For. Policy Econ. 49, 17-22.

Bartley, T., 2010. Transnational private regulation in practice: the limits of forest and labor standards certification in Indonesia. Busi. Politics 12 (3), 7, Art.

Bartley, T., 2014. Transnational governance and the re-centered state: sustainability or legality? Regul. Gov. 8, 93-109.

Bell, S., Hindmoor, A., 2012. Governance without government? The case of the forest stewardship council. Public Administration 90 (1), 144-159.

Bernstein, S., Cashore, B., 2012. Complex global governance and domestic policies: four pathways of influence. Int. Affairs 88, 585-604.

Burns, S.L., Giessen, L., 2014. Identifying the main actors and their positions on international forest policy issues in Argentina. Bosque 35 (2), 163-173.

Burns, S.L., Giessen, L., 2015. Dismantling Comprehensive Forest Bureaucracies: Direct Access, the World Bank, Agricultural Interests, and Neoliberal Administrative Reform of Forest Policy in Argentina. Soc. Nat. Resour., http:// dx.doi.org/10.1080/08941920.2015.1089608.

Cashore, B., 2002. Legitimacy and the privatization of environmental governance: how non state market-driven (NSMD) governance systems gain rule making authority. Governance 15 (4), 503-529.

Cashore, B., Auld, G., Newsom, D., 2003. Forest certification (eco-labeling) programs and their policymaking authority: explaining divergence among North American and European case studies. Forest Policy Econ. 5, 225-247.

Cashore, B., Auld, G., Newsom, D., 2004. Governing through Markets: Forest Certification and the Emergence of Non-state Authority. Yale University Press, New Haven.

Cashore, B., Van Kooten, G.C., Vertinsky, I., Auld, G., Affolderbach, J., 2005. Private or self-regulation? A comparative study of forest certification choices in Canada, the United States and Germany. Forest Policy Econ. 7, 53-69.

Davies, P.H.J., 2001. Spies as informants: triangulation and the interpretation of Elite interview data in the study of the intelligence and security services. Politics 21, 73-80.

Dietrich, A., Tosun, J., 2013. Forstzertifizierung in Europa: eine analyse der beitrittsmotive von staaten. Z. Umweltpolitik Umweltrecht 36, 292-316.

Espach, R., 2005. Private regulation amid public disarray: an analysis of two private environmental regulatory programs in Argentina. Busi. Politics 7 (2), Article 3.

Espach, R., 2006. When is sustainable forestry sustainable? The Forest stewardship council in Argentina and Brazil. Global Environ. Politics 6, 55-84.

Faggi, A.M., Zuleta, G.A., Homberg, M., 2014. Motivations for implementing voluntary environmental actions in Argentine forest companies. Land Use Policy 41, 541-549.

Gale, F., Haward, M., 2011. Global Commodity Governance: State Responses to Sustainable Forest and Fisheries Certification. Palgrave Macmillan, Basingstoke.

George, A.L., Bennett, A., 2005. Case Studies and Theory Development in the Social Sciences. MIT Press, Cambridge, MA and London, England. 
Giessen, L., 2013. Reviewing the main characteristics of the international forest regime complex and partial explanations for its fragmentation. Int. For. Rev. $15,60-70$.

Giessen, L., Krott, M., 2009. Forestry joining integrated programmes? A question of willingness, ability and opportunities. Allg. For. Jagdzeitung 180, 94-100.

Giessen, L., Buttoud, G., 2014. Defining and assessing forest governance. Forest Policy Econ. 49, 1-3.

Giessen, L., Krott, M., Möllmann, T., 2014. Increasing representation of states by utilitarian as compared to environmental bureaucracies in international forest and forest-environmental policy negotiations. Forest Policy Econ. 38, 97-104.

Grugel, J., Peruzzotti, E., 2010. Grounding global norms in domestic politics: advocacy coalitions and the convention on the rights of the child in Argentina. J. Latin Am. Stud. 42, 29-57.

Gulbrandsen, L.H., 2010. Transnational Environmental Governance: The Emergence and Effects of the Certification of Forests and Fisheries. Edward Elgar, Cheltenham, UK/Northampton (MA), USA, pp. 213 p.

Gulbrandsen, L.H., 2014. Dynamic governance interactions: evolutionary effects of state responses to non-state certification programs. Regul. Gov. 8, 74-92.

Ho, P., 2006. Credibility of institutions: forestry, social conflict and titling in China. Land Use Policy 23, 588-603.

Hofmann, F., 2002. Globale Waldpolitik in Deutschland?Eine Untersuchung über die Wirkung internationaler Regime in föderalen Strukturen. Albert-Ludwigs-Universität Freiburg.

Hogl, K., Nordbeck, R., Kvarda, E., 2009. When international impulses hit home: The role of domestic policy subsystem configurations in explaining different types of sustainability strategies. For. Policy Econ. 11, 357-364.

Humphreys, D., 2006. Logjam-deforestation and the crisis of global governance. Earthscan, London.

Hysing, E., 2009. Governing with government? The private governance of forest certification in Sweden. Public Administration 87 (2), 312-326.

Keskitalo, E.C.H., Sandström, C., Tysiachniouk, M., Johansson, J., 2009. Local consequences of applying international norms: differences in the application of forest certification in northern Sweden, northern Finland, and northwest Russia. Ecol. Soc. 14 (2), 1.

Koontz, T.M., Newig, J., 2014. From planning to implementation: top-down and bottom-up approaches for collaborative watershed management. Policy Stud. J. 42, 416-442

Krasner, S.D., 1982. Structural causes and regime consequences: regimes as intervening variables. Int. Organ. 36, 185-205.

Krott, M., 2005. Forest Policy Analysis. Springer, Dordrecht, Netherlands.

Levitsky, S., Murillo, M.V., 2008. Argentina: from Kirchner to Kirchner. J. Democracy 19, 16-30.

Lopreite, D., 2014. Explaining policy outcomes in federal contexts: the politics of reproductive rights in Argentina and Mexico. Bull. Latin Am. Res. 33, 389-404.

Lorenzoni, I., Benson, D., 2014. Radical institutional change in environmental governance: explaining the origins of the UK Climate Change Act 2008 through discursive and streams perspectives. Global Environ. Change 29, 10-21.

Neuman, W.L., 2005. Social Research Methods. Quantitative and Qualitative Approaches, 6th ed. Allyn and Bacon, London, UK.

Öberg, P., Svensson, T., Christiansen, P.M., Nørgaard, A.S., Rommetvedt, H., Thesen, G., 2011. Disrupted exchange and declining corporatism: government authority and interest group capability in Scandinavia. Gov. Oppos. 46, 365-391.

Pattberg, P., 2005. The institutionalization of private governance: how business and nonprofit organizations agree on transnational rules. Governance 18, 589-610.

Pattberg. P., 2007. Private Institutions and Global Governance. The New Politics of Environmental Sustainability. Edward Elgar, Cheltenham, UK and Northampton, USA, pp. 320 pp.

Pattberg, P., 2012. Transnational environmental regimes. In: Biermann, F., Pattberg, P. (Eds.), Global Environmental Governance Reconsidered. MIT Press, Cambridge, MA, p. 318 pp, ISBN 9780262017664.

Peters, B.G., 2010. The Politics of Bureaucracy-An Introduction to Comparative Public Administration, 6th ed. Routledge, Oxon.
Rayner, J., Howlett, M., Wilson, J., Cashore, B., Hoberg, G., 2001. Privileging the sub-sector: critical sub-sectors and sectoral relationships in forest policy-making. Forest Policy Econ. 2, 319-332.

Rommetvedt, H., Thesen, G., Christiansen, P.M., Nørgaard, A.S., 2012. Coping with corporatism in decline and the revival of parliament: interest group lobbyism in Denmark and Norway, 1980-2005. Comp. Political Stud. 46, 457-485.

Sahide, M.A.K., Nurrochmat, D.R., Giessen, L., 2015a. The regime complex for tropical rainforest transformation: analysing the relevance of multiple global and regional land use regimes in Indonesia. Land Use Policy 47, 408-425.

Sahide, M.A.K., Burns, S.L., Wibowo, A., Giessen, L., 2015b. Towards state hegemony over agricultural certilication: from voluntary private to mandatory state regimes on palm oil in Indonesia. Jurnal Manajemen Hutan Tropika (J. Trop. For. Manag.) 21 (3)

Scharpf, F.W., 2006. The joint-decision trap revisited. JCMS 44, 845-864

Shannon, M.A., Schmidt, C.H., 2002. Theoretical approaches to understanding intersectoral policy integration. In: Tikkanen, I., Glueck, P., Pajuoja, H. (Eds.), Cross-Sectoral Policy Impacts on Forests, EFI Proceedings, vol. 46. European Forest Institute, Joensuu, pp. 15-26 pp.

Tosun, J. 2012. Forest Certification in europe: exploring the determinants of cross-country variation. Marmara J. Eur. Stud. 22 (1), 177-197.

Tosun, J., 2013. Environmental policy change in emerging market democracies: Central and Eastern Europe and Latin America compared. In: Series: Studies in Comparative Political Economy and Public Policy. University of Toronto Press, Canada.

Wibowo, A., Giessen, L., 2015. Power Dynamics of the State Agencies in Forest Land Use Politics: Insights from the REDD+ Programme and the One Map Policy in Indonesia. Land Use Policy 49, 131-141.

Wibowo, A., Sahide, M.A.K., Giessen, L. Unpublished. Reclaiming legitimacyfrom voluntary private to mandatory state forest certification: Case ofIndonesia.

\section{Empirical references}

Argentina Forestal, 2007. La UE confirma la caida del Proyecto COMPYMEFOR. Available at: http://www.emprenderenlaregion.com.ar/?p=1285

Cerfoar, 2013a. Annex 5. Technical document. IRAM minutes of IRAM Working Group 2. Forest management meetings Summary.

Cerfoar, 2013b. Sistema argentino de certificación forestal.

Cerfoar, 2013c. Argentine Forest Certification System-cerfoar. Technical document.

Cerfoar, 2013d. List of participants.

Escobar, P., 2006. Formación técnica y certificación forestal son ejes de acción de Compymefor. Argent. For., Sep. 25

Forest Stewardship Council 2002. Carta nombramiento Javier Corcuera Persona Contacto Argentina.

Forest Stewardship Council 2014. Global FSC certificates: type and distribution (October 2014). Available at: https://ic.fsc.org/preview.facts-and-figuresoctober-2014.a-3695.pdf.

FVSA, 2002. El grupo de Trabajo FSC.

FVSA 2003. Informe final 2002-2003. Iniciativa Nacional Argentina FSC. Estado actual a Julio de 2003. Resúmen de actividades. Report from the national initiative to WWF.

MAGyP (Ministerio de agricultura, ganadería y pesca, AR). 2013. Área ambiental. Available at: http://64.76.123.202/new/0-0/forestacion/ tecnica\%20e\%20informacion/08_Area\%20Ambiental/04_ Acuerdos\%20Ambientales/index.php.

PEFC. 2013. Argentina seeks PEFC endorsment. Available at: http://www.pefc.org news-a-media/general-sfm-news/1325.

Sanchez Bonifato, C., 2001. Distinguen a Shell por sus negocios forestales. La Nación, Buenos Aires, Argentina. Jan. 27.

SAyDS (Secretaría de ambiente y desarrollo sustenTable, AR), 2005. Primer inventario nacional de bosques nativos. Proyecto bosques nativos y áreas protegidas BIRF 4085-AR 1998-2005, AR. 126 p. 

The World Bank's power on environmental and natural resources policies in Armenia: neoliberal changes and post-soviet heritage

World Development

Sarah L. Burns ${ }^{a, b *}$, Max $\operatorname{Krott}^{a}{ }^{a}$, Hovik Sayadyan ${ }^{c, d, e}$, Lukas Giessen ${ }^{a}$

*Corresponding author: ${ }^{a}$ University of Göttingen, Chair of Forest and Nature Conservation Policy, Germany,sarah.burns@forst.uni-goettingen.de

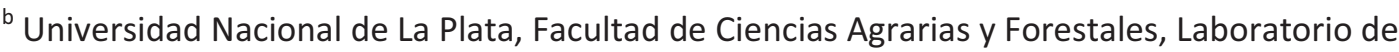
Investigación de Sistemas Ecológicos y Ambientales, La Plata, Argentina.

${ }^{\mathrm{c}}$ Chair of Forestry, Armenian National Agrarian University (ANAU)

${ }^{d}$ Faculty of Geography and Geology of Yerevan State University (YSU)

${ }^{\mathrm{e}}$ Akopian Environmental Center (American University of Armenia)

\title{
ACKNOWLEDGEMENTS
}

This research was supported by funding from the Eva Mayr-Stihl Foundation, the German Research Foundation (DFG PAK 813) and Erasmus Mundus Action 2 EUROPLATA partnerships.

\begin{abstract}
Over the past decades, development projects by international organizations like the World Bank use the concepts of "joint forest management", "community-based natural resource management" and "participatory conservation" as an integrated approach to poverty alleviation and conservation, promoting intensification of natural resource production. This new framework of neoliberal conservation governance promotes market-based mechanisms that aim to motivate local users to address environmental concerns by means of incentives. The aim of this study is to analyze the World Bank's power resources and its resulting influence on environmental and natural resources policies under the umbrella of poverty alleviation projects in a post-socialist fragile state using Armenia as a case. We use a qualitative case-study design building on content analysis of policy documents. Our results show that the World Bank interventions aiming to reduce rural poverty by means of improving natural resources
\end{abstract}


management in Armenia promoted policy and administrative changes that in the end favors big private companies while restricting the access to natural resources of poor local users. By identifying local actors as the main drivers of deforestation and with the discourse of illegal logging, the World Bank promoted privatization of the forestland as well as a reform of the forest administration deregulating the forest sector. The reform initiated by the World Bank introduced new planning instruments with the formal aim to strengthen the ecological goals in the natural resources management. In practice, the opposite happened: The deregulation increased harvesting and export quickly due to strong actors and the new plans came never into being because of weak state actors and governance processes in the implementation. The exploitative effects of natural resources reforms are not unique to Armenia. It seems that the mixture of effective deregulation and ineffective new governance provides a formal concept for legitimization of reforms. Informally, such an approach is doomed to fail -it is detrimental for sustainable forestry but benefits the informal winners who gain additional profits from the forest in these countries while restricting access to poor local users.

Keywords: bureaucratic politics; international organizations; neoliberal conservation governance

\section{Introduction}

Over the past decades, international organizations have promoted intensification of natural resource production by using the concepts of "joint forest management", "community-based natural resource management" and "participatory conservation" as an integrated approach to poverty alleviation and conservation (Dressler and Roth 2011). These large international organizations are considered the key actors, directing patterns of global change through their development projects (Singh 2009, Burns and Giessen 2016). By shifting the approach of conservation policies on environment and natural resources all over the world from a coercive one to a new framework of neoliberal conservation governance, promoting market-based mechanisms that aim to motivate local users to address environmental concerns by means of incentives, the relationship between resource users and the environment has been changed from production for domestic consumption to production of commodities in globalized capitalist markets owned by others (Harvey 2005, Fletcher 2010, Dressler and Roth 2011, Roth and Dressler 2012). This new trend in conservation, seen as a fundamental step towards sustainability, claims to be more inclusive to local users' needs, incorporating them through community-based natural resource management projects, and in doing so, creating a sense of shared responsibility among different actors (Otto and Chobotová 2013). However, market conservation governance has been criticized considerably in the last few years. Critics have claimed that rather than giving control to community members, neoliberal conservation policies that promote decentralization, privatization and commodification allow corporations and international actors to increase their influence over local natural resources (Levine 2002, Fletcher 2010, Roth and Dressler 2012). In order to induce global changes a certain type of authority is required, that can be explained by theories of power and 
emancipation (Manuel-Navarrete and Pelling 2015). Among the international organizations promoting this shift, the World Bank is considered as perhaps the most influential actor bringing about certain types of changes in developing countries (Singh 2009).

In post-socialist countries, market-driven conservation governance, along with other market-oriented approaches, became dominant during the transformation process starting after the Cold War. However, its implementation was especially challenging due to the previous system of complete state control, with limited private property and centralized administrative systems (Otto and Chobotová 2013). During this time of transformation, World Bank lending to post-soviet countries went to those undertaking big Structural Adjustment Programmes aiming to eradicate poverty by promoting sustainable social and political changes together with economic reforms (Davies and Woodward 2014), as in the case of Armenia. Such structural adjustment lending provided economic incentives to economic sectors, such as forestry and agriculture, to restructure government activity, shift activities to the private sector and downsize bureaucracies (Davies and Woodward 2014, 254). Besides the economic incentives, multilateral development banks provide knowledge to the borrower countries, by including their ideas in the project proposals as well as project management and technical expertise in the project design (Davies and Woodward 2014). Since 2005, multilateral and bilateral UN organizations like the World Bank adopted a new assistance approach integrating security, development and human rights into socalled 'fragile states' (Karsenty and Ongolo 2012). Fragile states can be defined as countries with a "lack of political capacity to provide the basic functions needed for poverty reduction, development and to safeguard the security and human rights of their populations" (OECD/DAC 2007, 29). In these countries, the state has no autonomy or power over different sectors, and these sectors manipulate the state based on their own interests, considering it a means to ensure their own private wealth accumulation (Karsenty and Ongolo 2012). This lack of power by the state challenges the influence international actors can have by means of incentives.

Although a number of studies has been conducted on environmental governance and development projects in the past years, including new neoliberal conservation governance (e.g., Levine 2002, Singh 2009, Fletcher 2010, Dressler and Roth 2011, Roth and Dressler 2012), there is a lack of research on the political power of these mechanisms (Cashmore et al. 2015, Manuel-Navarrete and Pelling 2015). Hence, the aim of this study is to analyze the World Bank's power resources and its resulting influence on environmental and natural resources policies aiming at poverty alleviation in a post-socialist fragile state using Armenia as a case.

\section{Theoretical approach}

Multiple international environmental negotiations take place continuously, resulting in a body of international environmental policy that is referred to as 'international environmental regimes' (Humphreys 2006). An international regime can be defined as a "set of implicit or explicit principles, norms, rules and decision-making procedures around which actors' expectations converge in a given area of international relations" (Krasner 1982, 186). The ways by which international regimes influence domestic policies can be categorized into "four pathways of influence, each with its own causal logic: through international rules; international norms and discourse; creation of or interventions in markets; and direct access to domestic policy processes" (Bernstein and Cashore 2012, 587). The direct access 
pathway refers to influence by means of direct funding, education, training, assistance and capacity building (Bernstein and Cashore 2000, 2012). This pathway is linked to providing incentives to domestic policy actors, which, according to the theory of incentives, can cause an actor's interest to change direction, and therefore functions as a critical resource of power (Karsenty and Ongolo 2012, Krott et al. 2014). Although it represents a very important form of influence, this path can be described as an "infiltration" in the domestic policy-making process (Bernstein and Cashore 2000). It is seen as intrusion and raises issues of sovereignty (Bernstein and Cashore 2012). As a consequence, direct access is most likely to be achieved with the support of specific domestic state actors who bring critical legitimacy to the process, which is essential in overcoming sovereignty concerns (Gulbrandsen 2003). In exchange, those domestic state actors that invite outside actors gain additional sources of power, such as legitimacy and financial resources (Peters 2010). These domestic state actors can be defined as domestic bureaucracies.

A bureaucracy can be defined as "a public institution that makes decisions concerning specific problems on the basis of general legal standards, resolving those problems by implementing special measures" (Krott 2005, 126). Every bureaucracy has both formal and informal goals. Formal goals are related to serving the public interest while the informal ones are related to surviving, as well as maximizing power, budget and staff (Krott 2005, Wibowo and Giessen 2015). The bureaucratic politics theory claims that bureaucracies compete with each other for resources, staff and responsibility for policy domain. This competition between bureaucracies with different preferences, abilities and power capabilities shapes the resulting policy to a great degree (Krott 2005, Peters 2010, Giessen et al. 2014). Bureaucracies have different sources of power that they use to produce policy change and increase their influence in the policy-making process. These power sources comprise three elements: coercion, incentives and nonverified information (Krott et al. 2014). Coercion is defined as altering the behavior of an actor by force (Krott et al. 2014). The main sources of bureaucracies' power based on coercion are their legal mandates (including decision rights and sanction mechanisms), technical resources (enabling bureaucracies to maintain a policy process) and alliances between bureaucracies and external actors putting pressure behind the preferences of a bureaucracy. (Dis)incentives are defined as advantages and disadvantages introduced to alter the behavior of an actor (Krott et al. 2014). The main sources of power based on incentives are transfer funds, creating a link to other issues and funds for setting incentives for others to follow their preferences and alliances between bureaucracies and external actors putting resources behind the preferences of a bureaucracy. Dominant information is defined as unverifiable information that makes the decision process more difficult for actors (Krott et al. 2014). The main sources of power based on selected information are the bureaucracies' expertise and active selection of information as well as interest-guided use of beliefs and values. Bureaucracies act in coalition with other public and private actors with compatible interests making up a policy sector (e.g. Forestry, Agriculture; Rayner et al. 2001, Giessen and Krott 2009). In joining forces, policy sectors attempt to influence public policy based on the overlaps of their actors' interests.

In order to influence domestic policies, international actors are likely to seek coalition with national bureaucracies. These coalitions can give international bureaucracies the opportunity of having direct access to domestic policy change. At the same time, as coalition partners, international bureaucracies 
can bring an additional source of power to national bureaucracies in their permanent competition with other bureaucracies for staff, resources and responsibilities (Peters 2010).

Considering this theoretical framework our hypotheses are:

International organizations, like the World Bank, use their different power elements in order to produce policy change at the national level. By means of incentives power, through loans and grants in the form of community-based natural resources management and poverty alleviation projects, they support market-based conservation, in line with neoliberal conservation governance, pushing institutional structures towards deregulation. By enforcing market models and private ownership, developing policy creates illegality, favoring private sector investment.

By using dominant information power as capacity building during projects' proposal, design and management, international organizations silence alternative policies by selecting national knowledge and expertise.

The influence of international organizations can operate through informal coercive power to support existing domestic bureaucracies or to help create new ones. In such cases, international actors and institutions are supported by specific bureaucracies at the cost of their domestic competitors with a resulting weakened national administration. Domestic bureaucracies will call upon international bureaucracies as allies in cases useful for them and their sector's societal clientele.

In states with weak capacities, where governments are only partially in control of legitimate means of force and are not in the position to implement political decisions, the lack of autonomy of these bureaucracies limits the influence international actors have at the national level.

3. Methodology

\subsection{Case description}

The Republic of Armenia, located in the southern Caucasus, has a total area of $29,800 \mathrm{~km}^{2}$ within 11 provinces. In 1828, the country was incorporated into Russia and later, in 1920, into the United Soviet Socialist Republics (USSR). Armenia achieved its independence when the USSR was disintegrated in 1991, in the middle of a war against Azerbaijan over Nagorno-Karabakh that lasted between 1988 and 1994. As a result of this war, and together with a devastating earthquake in 1988, the country ended up in severe economic and environmental damage, leading to political violence together with transport, economic and energy blockades (Sayadyan and Moreno-Sanchez 2006). This situation caused great pressure on the forests and other natural resources resulting in soil erosion, high deforestation rates and biodiversity loss (Sayadyan and Moreno-Sanchez 2006). Due to its location as well as its topographic complexity, forests in Armenia have a high percentage of plant and animal endemism, and are included in the Caucasus and Irano-Anatolian biodiversity hotspots (Sayadyan and Moreno-Sanchez 2006). By the year 1992, the total forest cover of Armenia was almost 460,000 ha, with about $11.2 \%$ of the country being wooded vegetation (Sayadyan and Moreno-Sanchez 2006). Since the Soviet period all forests are state owned and managed only for conservation and protection, according to the 1978 USSR Forestry Code which divided all forests into three categories, classifying all Armenian forests into Group I (protected forests) allowing only sanitary and reproductive cuts (Sayadyan and Moreno-Sanchez 2006). After independence, a new 
Armenian Forestry Code was published in 1994 based on the 1978 Soviet Forestry Code, again declaring all forests as state owned and reserved for protection and conservation (Sayadyan and Moreno-Sanchez 2006). In 1995, a new bureaucracy, Armforest State Forest Enterprise (Hayantar), in charge of forest management, was created under the Ministry of Nature Protection (FAO 1995, Sayadyan and MorenoSanchez 2006). At the same time, a new national forest policy aiming to make economic use of the forest was proposed, but this was never approved (Sayadyan and Moreno-Sanchez 2006). In 1998, the Forest Research Experimental Center (FREC) was created, also under the Ministry of Nature Protection, with the aim of forest monitoring and inventorying. However, coordination between these two forest-related bureaucracies was never achieved (Sayadyan and Moreno-Sanchez 2006). This lack of coordination and capacity of the forest bureaucracies, together with a high demand of forest products caused by the lack of imports from Russia, led to an increase in illegal logging of the forests (FAO 1995, Sayadyan and Moreno-Sanchez 2006). At this time, the economy began to recover, with stabilization and structural reforms driving a liberalization of the economy, small and medium privatizations and the formulation of a legal administrative framework for market economy. The Ministry of Nature Protection then invited the World Bank to assist them in the establishment of a new forest policy under the principles of sustainable forest management. This invitation led to the formulation of the "Armenian natural resources management and poverty alleviation" project with funding from both the World Bank and the Global Environment Facility (GEF) (World Bank 2002, 2009).

\subsection{Empirical methods}

To understand how the World Bank influences policy change through direct access, we conducted a qualitative case study of the World Bank-funded forest project and the resulting forest policy-making in Armenia from 2002 to the present. To do so, we employed process tracing (George and Bennett 2005). The method of process-tracing "attempts to trace the links between possible causes and observed outcomes" (George and Bennett 2005, 6), focusing on sequential processes within a particular historical case. By providing theory-based historical explanations for a case, in which each significant step towards the outcome is explained by making reference to a theory, process tracing becomes a powerful method of inference (George and Bennett 2005, 30). We collected data from different sources with the aim of determining whether the direct access by international bureaucracies, together with competing national bureaucracies and national non-governmental organizations, can be related to the restructuring of the national forestry administration and forest policy change. As a first step, we completed a document search of publicly available sources to gather World Bank proposal documents and project completion reports from 2002 to the present. Using these documents, we identified executive bureaucracies involved in the project. We then reviewed the websites of these bureaucracies to obtain published outputs of the projects. We subsequently conducted semi-structured interviews with experts about the role and influence of international actors and domestic state and non-state actors in the process. Interviews lasted between half an hour and two hours. If it was not possible to meet with the interviewees in person, we used phone calls or emails. In all cases, interviewees were promised confidentiality in order to ensure full disclosure (Koontz \& Newig 2014). We used all the data collected for triangulation between documentary sources and all the interviews, providing valid and reliable data (Silva et al. 2011, Koontz \& Newig 2014, Lorenzoni \& Benson 2014). If there were contradictions or differences in interpretation, priority was given to written records, as suggested by Davies (2001). 
We used a qualitative content analysis method to analyze all documents and interviews (Neuman 2005). We coded the information obtained from the different data sources and grouped it into three main categories, based on the research questions. These categories were: i) administrative structure; ii) policy content and iii) power elements.

\section{Results}

\subsection{Direct access, incentives power and market-based conservation creating illegality}

After independence, in 1991, Armenia's economy fell into a severe recession. In 1993, the GDP was almost half of the 1990 level. This economic crisis led to the impoverishment of many rural communities, with as much as 55\% of the country's population classified as poor (World Bank 2002). In 1994, after a period of hyperinflation, fiscal crisis and severe economic contraction, a new stabilization and structural reform program was carried out, together with trade and price liberalization, establishment of a legal framework for a market economy, privatization and reduction in government intervention, leading to a real GDP growth in 1998 of 7.2 percent per annum, between the highest values among the Commonwealth of Independent States (CIS) countries (World Bank 2009). These market-friendly economic reforms received important support from the World Bank, who as part of a strategy to reduce poverty and illegal logging, in coalition with the Ministry of Nature Protection, developed the "Natural Resources Management and Poverty Reduction Project". It took three years of preparation from identification to approval, during which time complex objectives and numerous activities were proposed (World Bank 2009). The final project, which started in 2002, consisted of four components: i) community-based watershed management; ii) state forest management; iii) protected areas management and biodiversity conservation; and iv) project management and administration. The project was to be implemented by the Ministry of Nature Protection with a total funding of USD 16 million of which USD 8.3 million was credit from the World Bank through the International Development Association (IDA), USD 5.1 million was a Global Environment Facility (GEF) grant, USD 1.1 million was from a Swedish Government grant through the Swedish International Development Cooperation Agency (SIDA) and USD 1.5 million was a contribution from the Armenian Government (World Bank 2009). The main objective of the project was to reduce rural poverty by means of improving natural resources management while at the same time protecting important natural resources (World Bank 2009). At this point, forest degradation was identified as one of the critical areas of natural resource government concern, with high deforestation rates, ineffective forest policy, legal and institutional frameworks, underfinanced forest institutions and limited control of illegal logging (World Bank 2009). Many attempts have been made to stop or regulate illegal logging since independence; however, the lack of capacity of the forest administration led these attempts to fail. In 1995, an initiative to establish a national forest program, in coalition with the United Nations Food and Agriculture Organization (FAO), began, however only some statements of forest policy were achieved (Forest Policy and Strategy 2004, Sayadyan 2005). As a solution to these problems the project aimed to review and improve forest-related legislation, reduce illegal logging, undertake forest certification and reform the forest administration (World Bank 2009). These objectives were mainly to be implemented with funding from SIDA through the Forest Institution Support Project. 
Besides the aim to reduce illegal logging and increase the quality, quantity and productivity of the forest cover, the project aimed to increase incomes of the participating communities, increase crop and livestock productivity, increase community participation in natural resources management decisions and reverse the degradation in pasture vegetation cover (World Bank 2009).

Among the activities incentivized by the project, under the component of Community-Based Watershed Management, each participating village received USD 15,000 for planting a mixture of indigenous tree and fruit species, fencing, and demarcation for protection and natural regeneration of degraded land adding up to 1,500 ha (World Bank 2009). However, after the project finished, the lack of resources to maintain these plantations threatened their survival. In addition, each village received USD 35,000 to perform livelihood improvement activities, including the construction of livestock watering points, restoration of field tracks, fertilization of community pastures, improvement and rehabilitation of village hay meadows, reintroduction of forage legumes into crop rotations, improved wheat and spring barley technology demonstrations, and bee keeping for honey (World Bank 2009).

With the aim of developing community forest management, three consecutive activities were proposed by the project. As a first step, community forestry management plans for former kolkhoz (collectivelyowned) and sovkhoz (state-owned) forest areas were supposed to be developed. Once these plans were approved, forest area management rights and responsibilities were supposed to be legally transferred to local communities or village-level organizations with a later investment in rehabilitation, reforestation, enrichment planting, or other improvements (World Bank 2009). However, the implementation of these activities was not successful. Only 7 out of the 12 planned forestry management plans were prepared and not even a single one of them was approved by the end of the project. As well, no legal transfer of the management rights was done. A similar situation was observed with the forest management plans, with two of the plans getting approval and three still pending. However, even though these plans were made, the implementation phase was not achieved. Both the community forestry management plans and the forest management plans were developed in order to comply with the World Bank's requirements, but no actual attempt to implement them was made.

In protected areas, management plans were supposed to be developed at the beginning of the Project, however, management plans for the Dilijan and Lake Sevan National Parks were only developed with modern international standards in 2007 when the plans were approved, leaving no time for implementation within the Project's duration. Moreover, the multi-sectoral consultation nature of the process led to major compromises on conservation aims (World Bank 2009). As a consequence, the quality and effectiveness of these plans, especially from the Lake Sevan National Park, were questionable. The level of the Lake Sevan had been lowered considerably over the previous decades due to water extraction with irrigation and hydropower purposes. In 2001, a program was prepared by the Ministry of Nature Protection to raise the level of the lake by 6 meters over a period of 30 years, with the aim of improving ecological conditions. During the development of the management plan, with funding from the World Bank, half-built and abandoned buildings from the Soviet era that would be flooded by the water level rise were identified and planned to be destroyed. However, before the plan was accepted, the lakeshore property was leased on a long-term period to private investors who were going 
to expand and modernize these buildings. The total number of buildings that would have been flooded was 150 , stopping the flooding plans.

As part of the "Natural Resources Management and Poverty Reduction Project" and with additional funding from the Swedish government through a SIDA grant, an "Illegal Logging Action Plan" was adopted in 2004 (Sayadyan 2005). According to official reports (decision N38, Government of Armenia 2004), unauthorized timber extraction for subsistence carried out by local communities was the main source of illegal logging in the country. The political and economic transition that took place after independence, together with the war against Azerbaijan between the years 1988 - 1994 and the disruption of goods and energy supplies from the Soviet Republic, led to a big energy crisis that could have led to an increase in illegal logging for subsistence reasons. However, the disruption of imports from Russia also included timber imports, which until 1991 comprised 95\% of the wood processing industry's raw material. This disruption was not reflected in the products of the wood industry, which from 1991 onwards had to obtain its raw material from illegal logging within Armenia, becoming probably the main driver of illegal logging in the country (Sayadyan 2005). In 1998, the Armenian forest administration (Hayantar) agreed to sell $2000 \mathrm{~m}^{3}$ of high quality oak from Armenian forests during a five year period to the Yerevan Brandy Company (Sayadyan 2005). However, according to the Forest Code (1994), the extraction of healthy oak trees is prohibited and this agreement could only be achieved by illegal logging.

Official market volumes for timber processing in 2005 represented USD 10 million, while the real estimates calculated a total of USD 132 million, more than ten times the official values. On the other hand, official market volumes of fuelwood in the same year represented USD 2.5 million while the real estimates were around USD 7.5 million, three times the official values. In the total real market value of wood, fuelwood represented less than $6 \%$ of the total. In terms of wood volume in the same year, official market volumes for timber processing were 6,600 million $\mathrm{m}^{3}$ while real volumes were estimated around 339,000 million $\mathrm{m}^{3}, 50$ times the official values, representing $54 \%$ of the total market volume. On the other hand, fuelwood official market volumes were $63,000 \mathrm{~m}^{3}$ while the real estimates were around $291,000 \mathrm{~m}^{3}$, almost five times the official values and representing $46 \%$ of the total market volume (Hergnyan et al. 2007). This data shows that although World Bank reports claimed fuelwood to be the main driver of deforestation through illegal logging, timber processing industries account for $60 \%$ of the total volume of illegally harvested wood (Hergnyan et al. 2007). While fuelwood consumption is driven mainly by poverty, representing $9 \%$ of the total households' means of cooking and heating in 2006, timber harvesting is driven by profit generation and affected by supply and demand factors (Hergnyan et al. 2007). The wood processing industry in Armenia is comprised of more than 300 small and mediumsized private actors with their main source of wood from illegally harvested sources. While the demand for fuelwood consumption is expected to decrease in the mid-term perspective, the commercial wood industry will continue to grow.

As a result of the "Illegal Logging Action Plan", permits from the Forest Enterprises to obtain fallen wood for fuelwood had been reduced and restricted, citing conservation aims. Hence, few households are able to obtain their wood directly from the forest and are forced to get it from intermediaries. This situation favors certain groups or individuals who are able to create rent opportunities. By the year 2010, more 
than $64 \%$ of households bought fuelwood from an intermediary, a significant increase in comparison to 52\% in 2003 (Junge and Fripp 2011). Even though local communities are not the main drivers of illegal logging, they are used as cheap labor force by private wood processing industries.

\subsection{Dominant information as capacity building leading to policy change}

The "Natural Resources Management and Poverty Reduction Project", implemented by the Ministry of Nature Protection, led to the formulation of the National Forest Policy and Strategy in 2004, the New Forest Code in 2005, the National Forest Program and the drafting of a Community Management Regulation (World Bank 2009).

The new Forest Code established that forests and forest lands can be under state, community and private ownership (Article 4 of the Forest Code 2005). This change allowed privatization of lands in cases where land users would afforest or reforest. Until this change, according to the Forest Code from 1994, land was all state owned. The Code also introduced the category of forests of production significance where wood production activities are allowed, with the approval of forest management plans (Article 10 and 13 of the Forest Code 2005). This new category of forests produced a changed towards an economic use of the forest from a pure conservation aim.

The project also incentivized the reform of legislation and regulations dealing with biodiversity conservation in protected areas. A new law on Specially Protected Natural Areas in Armenia was adopted in the year 2000, however, its implementation called for new bylaws. Although new regulations on monitoring and land registry were approved as a result, the Ministry of Justice did not approve regulations on land use. This new legislation would allow protected area administrations to generate and retain income (World Bank 2009).

Despite the large volumes of illegally harvested wood, there is no official definition of illegal logging in Armenia (Hergnyan et al. 2007), allowing the World Bank to use their own definition for the purpose of the project. By bringing in external experts as advisors as well as putting them in charge of different components of the project using dominant information power, the World Bank limits the range of alternatives, silencing some propositions and selecting choices in line with their own interests.

Also, as means of capacity building, SIDA provided support through the Swedish University of Agricultural Sciences for long-term cooperation on forestry education with the Armenian Agricultural Academy, establishing a Forestry Department in the Armenian Agricultural Academy in 2003. This cooperation provided equipment, literature and other facilities for forestry education as well as training and consultancy services (Sayadyan 2005).

\subsection{International organizations and national administration structure}

During 1992-2003, the forest management body of Armenia - the 'Hayantar' - underwent numerous restructurings, and as a result of each restructuring lost a part of its authority. As part of the forest sector institutional reforms carried out with funding from the project, 'Hayantar' became an organization within the structure of the Ministry of Agriculture, moving out of the Ministry of Nature Protection (Forest Policy and Strategy 2004). In addition to this change, there was an increase in budgetary 
allocations to this administration, improving its performance and effectiveness. From 2004 until the end of the project, funding of the forest sector increased tenfold (World Bank 2009). Until 2004, 'Hayantar' was responsible for implementing both forest management and control. Following the structural change carried out with support from the World Bank, the responsibility for control was given to the Ministry of Nature Protection (Governmental Resolution of the Republic of Armenia $\left.N^{\circ} 7,2004\right)$. However, there are three organizations with monitoring and control functions, the Forest State Monitoring Centre (FSMC), the newly created State Forest Service (SFS) and the State Environment Inspectorate (SEI), all within the Ministry of Nature Protection. Moreover, 'Hayantar' also controls illegal logging. This overlap between different administrations weakens the control activities (Elmqvist and Rylander 2010). The Ministry of Nature Protection, through the Forest Research Experimental Center (FREC), is responsible for forest inventory and planning as well as research and training. During the Soviet period, no academic forestry education was provided in Armenia, as a result 'Hayantar' employees have a low level of forest education, with only $4 \%$ of the staff members having undergone forestry education. This situation makes the formulation, implementation and control of sustainable forest management plans difficult.

\section{Discussion}

\subsection{Global influences changing domestic policy}

During the formulation stage of the project, international experts hired by the World Bank identified illegal logging, which they claimed was caused mainly by the demand for firewood by local actors (Hergnyan et al. 2007, World Bank 2009), as one of the main drivers of deforestation. Using illegal logging as a discourse pathway, they proposed, as part of the main aims of the project, policy changes to move towards production use of the forests and away from pure conservation. This would allow privatization of the forestland as well as a reform of the forest administration, moving the forest administration from the Ministry of Nature Protection to the Ministry of Agriculture. This is in line with previous studies that suggested that discourse, previously described as a pathway of international influences (Bernstein and Cashore 2012, Humphreys 2009, Leipold and Winkel 2016), is rather a prestage that prepares the way for the direct access pathway (Hogl et al. 2009, Burns and Giessen 2015) by means of incentives and dominant information power. The total volume of illegal logging due to fuelwood consumption reported in the World Bank reports differs from the values reported by local experts, exceeding their estimates by almost 55,000 households (Sayadyan 2005, Hergnyan et al. 2007). They assumed that local users were the main drivers of deforestation, and proposed policy changes attempted to improve the situation by promoting a change in the Forest Code, the formulation of a National Forest Policy and Strategy and a National Forest Program together with an Illegal Logging Action Plan (World Bank 2009). However, these changes only restricted local users from getting fallen wood from the forest for fuelwood and forcing them to obtain it from intermediaries.

\subsection{Global and domestic actors' power}

The role of external and local actors differs along the cycle of the projects. While in the formulation phase, external actors are more influential, it is the local actors in the implementation phase who have more power (Brukas and Hjorts $\varnothing 2004$, Singh 2009). During the preparation, design and management phase, international actors by means of dominant information limit the range of ideas by silencing alternative policies and selecting certain local actors and experts (Brukas and Hjorts $\varnothing$ 2004). This can be 
observed in the case of the 'Armenian natural resources management and poverty alleviation' project, where from a total of 17 experts participating in the formulation and implementation of the project, ten (almost 60\%) of the experts came from foreign countries and only seven from Armenia, representing equally the Ministry of Nature Protection, the Ministry of Agriculture and environmental NGOs. A similar case was observed in the forest sector in Lithuania where international organizations, with a political agenda and incentive power derived from funding resources, left limited access to local actors in the identification and preparation stages of the projects, keeping all decision-making authority (Brukas and Hjortsø 2004).

As a result of the World Bank project in Armenia, by means of direct access with incentive power, the forest administration structure and legislation were changed. As part of these changes, the forest administration, which used to be under the Ministry of Nature Protection, moved to the Ministry of Agriculture. Alongside this, the forestry administration body increased its budget; however, it also implied a reduction in policy domain, because control was lost over responsibilities that were given to the Ministry of Nature Protection, who also kept forest inventory and planning responsibilities through FREC. Through these changes, the forest policy domain became fragmented and the forest bureaucracies became less powerful, although their budgets were increased, at least during the duration of the project. This situation is similar to those observed in other countries by previous studies (Gautier et al. 2013, Burns and Giessen 2015). In Argentina, funding from the World Bank led to the dismantling of an autonomous forest bureaucracy into four different units within different ministries (Burns and Giessen 2015). In the case of Mali, also as a result of the World Bank intervention, the National Forest Administration lost its power, losing responsibilities and budget. In this case, the forest bureaucracy was not dismantled like in Argentina but weakened by the World Bank promoting the devolution of forest management to the local level and to a newly created bureaucracy funded by the World Bank, responsible for creating efficient markets (Gautier et al. 2013). In all these cases, the World Bank compensated bureaucracies for their loss in power by means of incentive power.

\subsection{Imbalance of deregulation, new government organization and new government means}

The reform initiated by the World Bank deregulated the forest sector by creating private forests. Simultaneously, the forest administration was restructured and new planning instruments were introduced with the formal aim to strengthen the ecological goals in the forest. In practice, the opposite happened: The deregulation increased harvesting and export quickly due to strong actors and the new plans came never into being because of weak state actors and governance processes in the implementation. The exploitative effects of forest reforms are not unique to Armenia. It seems that the mixture of effective deregulation and ineffective new governance provides a formal concept for legitimization of reforms. Informally, such an approach is doomed to fail -it is detrimental for sustainable forestry but benefits the informal winners who gain additional profits from the forest in these countries.

\subsection{Weak states and the influence of international actors}

Although several laws were formulated and later approved as a result of the 'Armenian natural resources management and poverty alleviation' project, the implementation was never achieved. Although the new Forest Code established the concept of private forests, even now there are no private forest owners 
in Armenia. The same was observed with both community forestry management plans and forest management plans, developed during the project in order to comply with the World Bank's requirements; however, until now no actual attempt to implement them has been made. This can be explained by the state's lack of power as pointed out by Karsenty and Ongolo (2012). A similar situation was observed in Lithuania, where the prevailing opinion is that the assistance projects in forestry have not had a significant influence on the development of the sector (Brukas and Hjorts $\varnothing$ 2004). While international projects have produced many legislative proposals, only a few have been enacted (Brukas and Hjorts $\varnothing$ 2004). This is a very different situation from what was observed in Argentina, where projects funded by the World Bank led to the development of a new forest law, which was immediately implemented (Burns and Giessen 2015).

\section{Conclusion}

In Armenia, the World Bank, as an international organization and by means of funding and capacity building, assisted the coalition of agricultural and profit-oriented bureaucracies and landowner associations (of forestry and agriculture) that emerged after the independence of the country at the beginning of the 1990s. With a trend towards neoliberal conservation governance, by forming coalitions with the World Bank, certain bureaucratic units were able to increase their staff and budget and produce valuable information, thereby increasing their power. This agrees with our theory, in that international organizations can operate through the provision of funding and capacity building to assist the existing domestic coalitions of bureaucracies and associations in their constant competition for power, or to help create new ones. Because bureaucracies like the Ministry of Nature Protection and the Ministry of Agriculture were in permanent competition, they invited the World Bank with the aim of increasing their domestic power at the cost of their domestic competitors. This invitation led to the establishment of influence through direct access of the World Bank, as an international organization, on domestic natural resource and environment policy and administration under the umbrella of poverty reduction projects. The reform influenced by the World Bank introduced new planning instruments with the formal aim to strengthen the ecological goals in the natural resources management. In practice, the opposite happened: The deregulation increased harvesting and export quickly due to strong actors and the new plans came never into being because of weak state actors and governance processes in the implementation. The mixture of effective deregulation and ineffective new governance provides a formal concept for legitimization of reforms. Informally, such an approach is doomed to fail -it is detrimental for sustainable natural resources management but benefits the informal winners who gain additional profits in these countries while restricting access to poor local users.

\section{References}

Bernstein, S., and B. Cashore. 2000. Globalization, Four Paths of Internationalization and Domestic Policy Change: The Case of EcoForestry in British Columbia, Canada. Canadian Journal of Political Science 33: 67-99

Bernstein, S., and B. Cashore. 2012. Complex global governance and domestic policies: four pathways of influence. International Affairs 88: 585-604

Brukas, V. and C.N. Hjortsø. 2004. A Power Analysis of International Assistance to Lithuanian Forestry, Scandinavian Journal of Forest Research 19: 166-176, DOI: 10.1080/14004080410034254 
Burns, S.L., and L. Giessen. 2015. Dismantling comprehensive forest bureaucracies: direct access, the World Bank, agricultural interests, and neoliberal administrative reform of forest policy in Argentina. Society and Natural Resources. DOI:10.1080/08941920.2015.1089608

Davies, P.H.J. 2001. Spies as informants: triangulation and the interpretation of Elite interview data in the study of the intelligence and security services. Politics $21: 73-80$.

Davies, M., and R. Woodward. 2014. International Organizations. A Companion. Edward Elgar Publishing Limted, Cheltenham, UK. ISBN 9781783474165

Dressler, W., and R. Roth. 2011. The Good, the Bad, and the Contradictory: Neoliberal Conservation Governance in Rural Southeast Asia. World Development 39:851-862

Elmqvist, M., and L. Rylander. 2010. Outcome Review of SIDA'S Development Cooperation with Armenia 1999-2009. Final Report. SIDA Review 2010:21.

Fletcher, R. 2010. Neoliberal Environmentality: Towards a Poststructuralist Political Ecology of the Conservation Debate. Conservation and Society 8: 171-181

Gautier, D., T.A. Benjaminsen, L. Gazull, and M. Antona. 2013. Neoliberal Forest Reform in Mali: Adverse Effects of a World Bank "Success". Society \& Natural Resources 26:702-716.

George, A.L., and A. Bennett. 2005. Case Studies and Theory Development in the Social Sciences. Cambridge, MA and London, England: MIT Press.

Giessen, L., and M. Krott. 2009. Forestry Joining Integrated Programmes? A question of willingness, ability and opportunities. Allgemeine Forst- und Jagdzeitung 180: 94-100.

Giessen, L., M. Krott, and T. Möllmann. 2014. Increasing representation of states by utilitarian as compared to environmental bureaucracies in international forest and forest-environmental policy negotiations. Forest Policy and Economics 38: 97-104.

Gulbrandsen, L. 2003. The evolving forest regime and domestic actors: strategic or normative adaptation? Environmental Politics 12: 95-114.

Harvey, D. 2005. A brief history of neoliberalism. Oxford: Oxford University Press.

Hergnyan, M., Hovhannisyan, S., Grigoryan, S., and Sayadyan, H. 2007. The Economics of Armenia's Forest Industry. Economy and Values Research Center. 54 pp.

Hogl, K., R. Nordbeck, and E. Kvarda. 2009. When international impulses hit home: The role of domestic policy subsystem configurations in explaining different types of sustainability strategies. Forest policy and economics 11: 357-364.

Humphreys, D. 2006. Logjam - Deforestation and the crisis of global governance. Earthscan, London.

Humphreys, D. 2009. Discourse as ideology: Neoliberalism and the limits of international forest policy. Forest Policy and Economics 11: 319-325.

Junge, N., and E. Fripp. 2011. Understanding the forestry sector of Armenia: current conditions and choices. FLEG. Main Report. 56 pp.

Karsenty, A. and S. Ongolo. 2012. Can "fragile states" decide to reduce their deforestation? The inappropriate use of the theory of incentives with respect to the REDD mechanism. Forest Policy and Economics 18: 38-45.

Koontz, T.M., and J. Newig. 2014. From Planning to Implementation: Top-Down and Bottom-Up Approaches for Collaborative Watershed Management. Policy Studies Journal 42: 416-442. 
Krasner, S.D. 1982. Structural Causes and Regime Consequences: Regimes as Intervening Variables. International Organization 36:185-205.

Krott, M. 2005. Forest policy analysis. Dordrecht, Netherlands: Springer.

Krott, M., A. Bader, C. Schusser, R.R. Devkota, A. Maryudi, L. Giessen, and H. Aurenhammer. 2014. Actorcentred power: The driving force in decentralised community based forest governance. Forest Policy and Economics 49:34-12

Leipold, S. and G. Winkel. 2016. Divide and conquer-Discursive agency in the politics of illegal logging in the United States. Global Environmental Change 36:35-45

Levine, A. 2002. Convergence or convenience? International conservation NGOs and development assistance in Tanzania. World Development30: 1043-1055.

Lorenzoni, I., and D. Benson. 2014. Radical institutional change in environmental governance: Explaining the origins of the UK Climate Change Act 2008 through discursive and streams perspectives. Global Environmental Change 29: 10-21.

Manuel-Navarrete, D., and M. Pelling. 2015. Subjectivity and the politics of transformation in response to development and environmental change. Global Environmental Change 35: 558-569

Neuman, W.L. 2005. Social research methods. Quantitative and qualitative approaches. 6th ed. London, UK Allyn and Bacon.

OECD/DAC. 2007. Fragile States: Policy Commitment and Principles for Good International Engagement in Fragile States and Situations. DCD/DAC, Paris.

Peters, B.G. 2010. The Politics of Bureaucracy- An Introduction to Comparative Public Administration. Sixth edition. Routledge. Oxon

Rayner, J., M. Howlett, J. Wilson, B. Cashore, and G. Hoberg. 2001. Privileging the sub-sector: critical subsectors and sectoral relationships in forest policy-making. Forest Policy and Economics 2: 319-332.

Roth, R.J. and W. Dressler. 2012. Market-oriented conservation governance: The particularities of place. Geoforum 43:363-366

Sayadyan, H. 2005. Ensuring sustainability of forests and livelihoods through improved governance and control of illegal logging for economies in transition. Working Document - Armenia for the World Bank. Savcor Indufor Oy. 44pp

Sayadyan, H., and R. Moreno-Sanchez. 2006. Forest policies, management and conservation in Soviet (1920-1991) and post-Soviet (1991-2005) Armenia. Environmental Conservation 33: 1-13

Singh, S. 2009. World Bank-directed Development? Negotiating Participation in the Nam Theun 2 Hydropower Project in Laos. Development and Change 40:487-507

Silva, H.T., P. De Paepe, W. Soors, O.V. Lanza, M.C. Closon, P. Van Dessel, and J.P. Unger. 2011. Revisiting health policy and the World Bank in Bolivia. Global Social Policy 11: 22-44.

Wibowo, A., and L. Giessen. 2015. Power Dynamics of the State Agencies in Forest Land Use Politics: Insights from the REDD+ Programme and the One Map Policy in Indonesia. Land Use Policy 49: 131-141.

World Bank. 2002. Project appraisal document on 'Natural Resources Management and Poverty Reduction Project'. Report No: 24043-AM, World Bank. http://documents.worldbank.org/curated/en/2002/05/1788057/armenia-natural-resources-

management-poverty-reduction-project (accessed August 4, 2015). 
World Bank. 2009. World Bank implementation completion and results report 'Natural Resources Management and Poverty Reduction Project'. Report No: ICR 1040, http://documents.worldbank.org/curated/en/2009/09/11215564/armenia-natural-resourcesmanagement-poverty-reduction-project (accessed April 8, 2015). 
In recent decades, globalization and internationalization led to an increase in the number of international regimes attempting to influence national behaviour over many different issues. By using the case of the international forest regime complex this thesis seeks to evaluate how an international organization such as the World Bank and private institutions of forest certification influence domestic forest policy. The cases of Argentina and Armenia were selected as examples of developing countries open to international influences with weak forest sectors that went through a recent administrative restructuring. In so doing this dissertation seeks to answer how do international and transnational organizations influence domestic forest policies? The results show that: the influence of the World Bank in Argentina and Armenia pushed the forest sector towards deregulation; state bureaucracies play an important role in the implementation of transnational regimes at the national level; the political system of federal countries provides multiple institutional access points for policy change that international and transnational regimes try to use in order to influence the domestic level, consequently changing the power balance of the domestic networks. 